\title{
A SURVEY OF GAS-SIDE FOULING MEASURING DEVICES
}

By

W. J. Marner

S. P. Henslee

March 1984

Work Performed Under Contract Nos. Al07-80ID12138

AC07-76ID01570

Jet Propulsion Laboratory

Pasadena, California

Technical Information Center

Office of Scientific and Technical Information United States Department of Energy 


\section{DISCLAIMER}

This report was prepared as an account of work sponsored by an agency of the United States Government. Neither the United States Government nor any agency Thereof, nor any of their employees, makes any warranty, express or implied, or assumes any legal liability or responsibility for the accuracy, completeness, or usefulness of any information, apparatus, product, or process disclosed, or represents that its use would not infringe privately owned rights. Reference herein to any specific commercial product, process, or service by trade name, trademark, manufacturer, or otherwise does not necessarily constitute or imply its endorsement, recommendation, or favoring by the United States Government or any agency thereof. The views and opinions of authors expressed herein do not necessarily state or reflect those of the United States Government or any agency thereof. 


\section{DISCLAIMER}

Portions of this document may be illegible in electronic image products. Images are produced from the best available original document. 


\title{
DISCLAIMER
}

\begin{abstract}
This report was prepared as an account of work sponsored by an agency of the United States Government. Neither the United States Government nor any agency thereof, nor any of their employees, makes any warranty, express or implied, or assumes any legal liability or responsibility for the accuracy, completeness, or usefulness of any information, apparatus, product, or process disclosed, or represents that its use would not infringe privately owned rights. Reference herein to any specific commercial product, process, or service by trade name, trademark, manufacturer, or otherwise does not necessarily constitute or imply its endorsement, recommendation, or favoring by the United States Government or any agency thereof. The views and opinions of authors expressed herein do not necessarily state or reflect those of the United States Government or any agency thereof.
\end{abstract}

This report has been reproduced directly from the best available copy.

Available from the National Technical Information Service, U. S. Department of Commerce, Springfield, Virginia 22161.

Price: Printed Copy A07

Microfiche A01

Codes are used for pricing all publications. The code is determined by the number of pages in the publication. Information pertaining to the pricing codes can be found in the current issues of the following publications, which are generally available in most libraries: Energy Research Abstracts (ERA); Government Reports Announcements and Index (GRA and I); Scientific and Technical Abstract Reports (STAR); and publication NTIS-PR-360 available from NTIS at the above address. 


\section{. A Survey of Gas-Side Fouling Measuring Devices}

W.J. Marner

S.P. Henslee *

March 1984

Prepared for

U.S. Department of Energy Idaho Operations Office

Through an Aoreement with

National Aeronautics and Space Administration

by

Jet Propulsion Laboratory

Caiforna Insitile of Tecnnology

Pasadena. Caitornid

- EG\&G Idaino. Inc

Idaho Falls. Idaho 
THIS PAGE

\section{WAS INTENTIONALLY LEFT BLANK}




\section{ABSTRACT}

A survey of measuring devices or probes, which have been used to investigate gas-side fouling, has been carried out. Five different types of measuring devices are identified and discussed including: heat flux meters, mass accumulation probes, optical devices, deposition probes, and acid condensation probes. A total of 32 different probes are described in detail and summarized in matrix or tabular form. The important considerations of combustion gas characterization and deposit analysis are also given a significant amount of attention: The results of this study show that considerable work has been done in the development of gas-side fouling probes. However, it is clear that the design, construction, and testing of a durable, versatile probe -- capable of monitoring on-line fouling resistances -- remains a formidable task. 


\section{ACKNOWLEDGEMENTS}

The information for this study was obtained through a literature search and personal contacts, including a visit to the United Kingdom. It is a pleasure to acknowledge the following persons who provided technical input for the present study: R. C. Attia. University of Tennessee Space Institute, Tullahoma, Tennessee; H. N. Tran, University of Toronto, Toronto, Canada: R. A. Wenglarz, Westinghouse R\&D Center, Pittsburah, Pennsylvania; Fred Kohl, NASA-Lewis Research Center, Cleveland, Ohio; Daniel Rosner, Yale University, New Haven, Connecticut; Frank Honea, Grand Forks Energy Terchnology Center, Grand Fork's, North Uakota: R. C. Weierman, Fscoa Fintube Corporation, Pryor, Oklahoma: A. L. Plumley, Combustion Engineering, Inc.. Windsor, Connecticut; Kichard W: Bryers, Foster Wheeler Development Corporation, Livingston, New Jersey: David Reay, AERE Harwell. Oxfordshire, United Kingdom; T. R. Bott and C. R. Bemrose, University of Birmingham, United Kingdom; Peter Jackson, Central Electricity Generating Board, Marchwood Laboratory, United Kingdom; Will Gibb, Midlands Region Scientific Services Department, United Kingdom; and James D. Isdale, National Engineering Laboratory, East Kilbride, Glasọow, Scotland. Special thanks go to Dee Darrow of the Jet Propulsion Laboratory for typing the entire manuscript.

This work was carried out through a joint effort between the Jet Propulsion Laboratory (JPL), California Institute of Technology, Pasadena, California, and EG\&G Idaho, Inc., Idaho Falls, Idaho. This project was sponsored by the U.S. Department of Energy, Office of Fnergy Systems Research, Energy Conversion and Utilization Technology (ECUT) Program. The work at JPL was carried out under Interagency Agreement DE-A107-80ID12138, through NASA Task Order RE-152, Amendment 300. The work at EG\&G Idaho, Inc. was carried out. under DOE Contract DE-AC07-76ID01570. The ter.hniral monitor for this project was W. H. Thielbahr, Chief, Energy Conservation Branch, U.S. Department of Enerqy, Idaho Operations office, Idaho Falls, Idaho. His continuing interest in, and support of, gas-side fouling made this effort possible. 
NOMENCLATURE

\begin{tabular}{|c|c|}
\hline A & surface area \\
\hline$C_{p}$ & specific heat \\
\hline d & probe diameter \\
\hline D & disc diameter \\
\hline $\mathrm{h}$ & convect ive heat transfer coefficient \\
\hline k & thermal conductivity of gas "' \\
\hline$k_{f}$ & thermal conductivity of fouling layer \\
\hline 1 & length \\
\hline $\mathrm{Nu}$ & Nusselt number \\
\hline $\operatorname{Pr}$ & Prandt 1 number \\
\hline$q$ & heat transfer \\
\hline$q_{w}$ & wall heat flux \\
\hline $\operatorname{Re}$ & Reynolds number \\
\hline$R_{f}$ & fouling factor or resistance \\
\hline$t_{f}$ & fouling layer thickness \\
\hline$T_{g}$ & gas temperature \\
\hline$T_{1}$ & inlet coolant temperature \\
\hline$T_{2}$ & outlet coolant temperature \\
\hline$V_{\mathrm{g}}$ & gas velocity \\
\hline$W$ & mass flowrate \\
\hline Acronyms & $\therefore$ \\
\hline
\end{tabular}

$A A$

$B C$

$C A$

CCM

C. J

CM

CS

CT

DPM
Atomic Absorption

Bomb Calorimetry

Chemical Analysis

Controlled Condensation Method

Cascade Impactor

Chemiluminescence Methods

Cone Slumping

Chromatographic Techniques

Dew-Point Meter 


\begin{tabular}{|c|c|}
\hline DTA & Differential Thermal Analysis \\
\hline ECM & Electrochemical Cell Method \\
\hline EDAX & Energy Dispersive X-Ray Analys is \\
\hline DS & Energy Dispersive Spectrometry \\
\hline EM & Electron Microprobe \\
\hline EPA Method 5 & Environmental Protection Agency Method 5 \\
\hline EPA Method 6 & Environmental Protection Agency Method 6 \\
\hline EPA ST & Environmental Protection Agency Sampling Train \\
\hline ID & Flame Ionization Detector \\
\hline FP & Flame Photometry \\
\hline FS & Fiuid Spectrometry \\
\hline FSS & Float Sink Separation \\
\hline$G A$ & Gravimetric Analysis \\
\hline CC & Gas Chromatogr aphy \\
\hline GLC & Standard Gas and Liquid Chromatography \\
\hline HPLGPC & Hig̣h Pressure Liquid and Gel Permeation Chromatography \\
\hline ISP & Isokinetic Sampling Probe \\
\hline IR & Infrared Spectroscopy \\
\hline MS & Mass Spectrometry \\
\hline NA & Neutron Activation \\
\hline NDIR & Non-nispersive Infrared Method \\
\hline 0 & Optical \\
\hline$O A$ & Orsat Analysis \\
\hline OES & Ontiral Fmisçinn Spectrochamical Analysis \\
\hline OM & Optical Microscopy \\
\hline PT & Paramagnetic Techniques \\
\hline SDA & Sulfur Dioxide Analyzer \\
\hline SEM & Scanning Electron Microscopy \\
\hline $\bar{T} \dot{G A}$ & Thermogravimetric Analysis \\
\hline XPS & $X$-Ray Photoelectron Spectrometry \\
\hline $\operatorname{XRO}$ & $x-k a y$ Uiffraction \\
\hline RF & X-Ray Fluorescence \\
\hline
\end{tabular}

vi. 


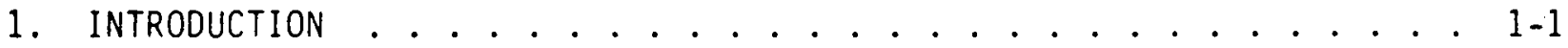

2. CLASSIFICATION OF GAS-SIDE FOULING MEASURING DEVICES ...... 2-1

3. STATE-OF-THE-ART REVIEW OF EXISTING GAS-SIDE FOULING MEASURING DEVICES ....................... . . . . . .

3.1 HEAT FlUX METERS . . . . . . . . . . . . . . 3-2

3.2 MASS ACCUMULATION PROBES . . . . . . . . . . . . 3-9

3.3 OPTICAL DEVICES . . . . . . . . . . . . . . . 3-30

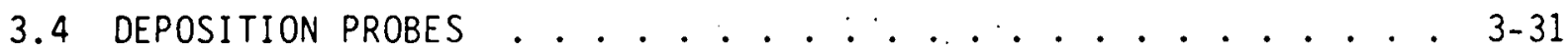

3.5 ACID CONDENSATION PROBES . . . . . . . . . . . . . 3-47

3.6 RECENT DEVELOPMENTS IN THE UNITED KINGDOM . . . . . . . . 3-51

4. GAS-SIDE FOULING PROBE SURVEY MATRIX ................ . . 4-1

5. RECOMMENDATIONS FOR THE DESIGN OF A GAS-SIDE FOULING PROBES . . . . 5-1

5.1 REQUIREMENTS FOR CHARACTERIZATION OF COMBUSTION GASES . . . . . 5-1

5.2 GAS-SIDE FOULING PROBE REQUIREMENTS . . . . . . . . . . . 5-1

5.3 DEPOSIT ANALYSIS REQUIREMENTS . . . . . . . . . . 5 5

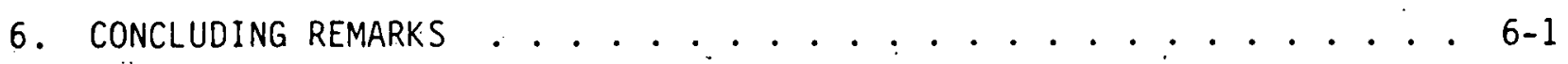

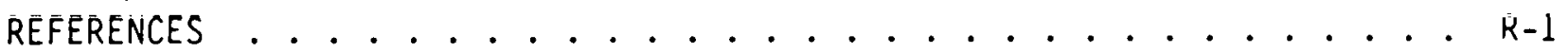


3-1. Basic Principle of the Heat Flux Meter. . . . . . . . . . . . . 3-3

3-2. Disc-Type Heat Flux Meter Developed ty Northover and Hitchcock . 3-3

3-3. The Two Types of Boiler Tube Heat Flux Measuring Devices. . . 3-6

3-4. Cranked and Dimpled Versions of the Central Electricity Research. Laboratories Fluxtube . . . . . . . . . . . . . . 3-6

3-5. Detail Design of the CERL Dometer Heat Flux Meter . . . . . . 3-7

3-6. Air-Cooled Mass Accumulat ion Probe Developed by Brown. et al.

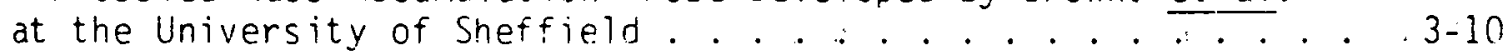

3-7. RWE Mass Accumulal Ion Prothe . . . . . . . . , . . . . . . . . $3-11$

3-8. David Taylor R\&D Center Heat Pipe Mass Accumulation Probe . . . 3-12

3-9. Mass Accumulation. Probe Developed at the Boris Kidrich Institute, Yugoslavia..................... . . . . . . . . . . . . .

3-10. Central Research Laboratories Mass Accumulation Probe : . . . . 3-16

3-11. Central Electricity Research Laboratories Mass Accumulation

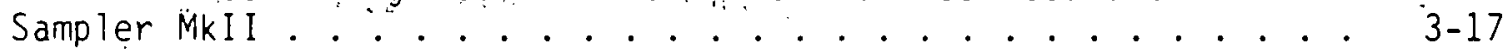

3-12. National Engineerino Laboratory Mass Accumulation Probe Hfad . . 3-19

3-13. National Engineering Laboratory Mass Accumulation Probe Assembly · 3-20

3-14. Schematic Drawing of National Engineering Laboratory Mass Accumulation Model MK 2 Prute Head................ . . . 3-21

3-15. CEGB Steam-Cooled U-Tube Mass Accumulation Probe . . . . . . 3-22

3-16. NASA-Lewis Rotating Cylinder Mass Accumulation Collector . . . 3-23

3-17. Fouled Probes in Grand Forks Energy Research Center Combustor . 3-26

3-18. Test Section of Mass Accumulation Probe Located at the Polytechnic, Wolverhampton .............. . . 3-29

3-19. Optical Mass Accumulation Probe Setup at Yale University. . . 3-31

3-20. Deposit Formation on an Air-Cooled Probe in a Kraft Recovery Boiler ............................. 3-33

3-21. Rurner and Probe Assembly at the CSIKO Vivision of Process Technology, North Ryde, Australia.......... . . 3-34 
Figures (Cont'd)

Page

3-22. Superheater Deposition Probe at the University.)f Tennessee Space Institute MHD Facility ............... . . 3-36

3-23. Schematic Drawing of Battelle Columbus Laboratories Deposition Probe . . . . . . . . . . . . . . . . . . 3-38

3-24. Schematic Drawing of Temperature Control System for Combustion Engineering Solid Fuel Burning Test Facility . . . : . . . . 3-41

3-25. Combustion Engineering Field Test Deposition Probe Showing Individual Segment Detail . . . . . . . . . . . 3-41

3-26. Electric Energy, Inc. Deposition Probe Before and After Exposure.................. ..... 3-42

3-27. Schematic of Electric Energy, Inc. Deposition Probe Including Temperature Controller............ . . . . . 3-43

3-28. Typical Arrangement of Materials in Solar Turbines Incorporated Study................. 3-46

3-29. Acid Condensation Probe Developed by Ross . . . . . . . . . . 3-48

3-30. Essential Features of the BCURA ACid Condensation Probe . . . 3-50

5-1. Schematic View of a Fouled Surface . . . . . . . . . . . . 5-3 
Tables

4-1. Gas-Side Foulina Probe Survey Matrix: Central Electricity

4-2. Gas-Side Fouling Probe Survey Matrix: Central.Electricity Research Laboratories, Leatherhead, Surrey, United Kingdom . . . . 4-4

4-3. Gas-Side Fouling Probe Survey Matrix: University of Waterloo, Water 100 , Ontario, Canada ............. 4-5

4-4. Gas-Side Fouling Probe Survey Matrix: University of Sheffield, United Kingdom .................. 4-6

4-5. Gas-Side Fouling Probe Survey Matrix: Rheinisch-Westfalisches Elcktrizatswcrk AG, Federal Reput lic of Gerillany ....... 4-7

4-6. Gas-Side Fouling Probe Survey Matrix: David W. Taylor Naval Ship R\&D Center, Bethesda, Marylarid ......... 4-8

4-7. Gas-Side Fouling Probe Survey Matrix: Institute for Thermal Engineering and Energy Research, Vinca, Yugoslavia...... 4-9

4-8. Gas-Side Fouling Probe Survey Matrix: Exxon Research and Engineering Company, Baytown, Texas .......... 4-10

4-9. Gas-Side Fouling Probe Survey Matrix: Central Electricity Generating Board, United Kingdom ........... 4-11

4-10. Gaș-Side Fouling Probe Survey Matrix: Central Electricity Research Laboratories, Leatherhead, Surrey, United Kingdom . . . 4-12

4-11. Gas-Side Fouling Probe Survey Matrix: National Engineering Laboratory, East Kilbride, Glasgow, Scot land ........ 4-13

4-12. Gas-Side Fouling Probe Survey Matrix: Central Electricity Generating Board, United Kingdom . . . . . . . . . 4-14

4-13. Gas-Side Fouling Probe Survey Matrix: NASA-Lewis Research Center, Cleveland, Ohio ............... 4-15

4-14. Gas-Side Fouling Probe Survey Matrix: Solar Turbines International, San Diego, California......... 4-16

4-15. Gas-Side Fouling Probe Survey Matrix: Central Electricity Generating Board, United Kingdom ........... 4-17

4-16. Gas-Side Fouling Probe Survey Matrix: Grand Forks Energy Research Center, Grand Forks, North Dakota .......... 4-18

4-17. Gas-Side Fouling Probe Survey Matrix: Westinghouse Research and Development Center, Pittsburgh, Pennsylvania ....... 
4-18. Gas-Side Fouling Probe Survey Matrix: Department of Physical Sciences, The Polytechnic, Wolverhampton, United Kingdom .... 4-20

4-19. Gas-Side Fouling Probe Survey Matrix: Yale University, New Haven, Connecticut .............. 4-21

4-20. Gas-Side Fouling Probe Survey Matrix: University of Toronto, Toronto; Ontario, Canada............. 4-22

4-21. Gas-Side Fouling Probe Survey Matrix: Bureau of Mines, U.S. Department of the Interior, Washington, D.C. . . . . . 4-23

4-22. Gas-Side, Fouling Probe Survey Matrix: CSIRO Division of Process Technology, North Ryde, Australia . . . . . . . . 4-24

4-23. Gas-Side Fouling Probe Survey Matrix: University of Tennessee Space Institute, Tullahoma, Tennessee $. \ldots . . . .44-25$

4-24. Gas-Side Fouling Probe Survey Matrix: Battelle Columbus Laboratories, Columbus, Ohio ........... 4-. . . . .

4-25. Gas-Side Fouling Probe Survey Matrix: Cambustion Engineering, Inc., Windsor, Connect icut ............ 4-27

4-26. Gas-Side Fouling Probe Survey Matrix: Electric Energy, Inc.,

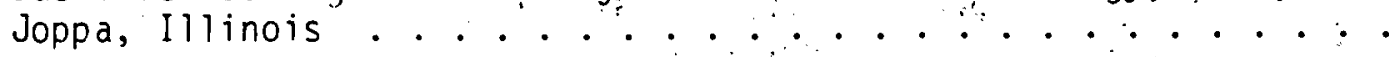

4-27. Gas-Side Fouling Probe Survey Matrix: Battelle Memorial Inst itute, Columbus, Ohio ............ 4-29

4-28. Gas-Side Fouling Probe Survey Matrix: Solar Turbines Incorporated, San Diego, California. .......... 4-30

4-29. Gas-Side Fouling Probe Survey Matrix: Central Electricity Research Laboratories, United Kingdom .......... 4-31

4-30. Gas-Side Fouling Probe Survey Matrix: Shell Research,.. Limited, Thornton Research Centre, Chester, United Kingdom . . . . 4 4-32

4-31. Gas-Side Fouling Probe Survey Matrix: Land Pyrometers Limited, Dronfield, Sheffield, United kingdom ......... 4-33

4-32. Gas-Side Fouling Probe Survey Matrix: Technical Center of Industries, Aerauliques, Villeurbanne, France ......... 


\section{SECTION 1}

\section{INTRODUCTION}

Gas-side fouling is a subject which has been of interest for a number of years. Most of the earlier work in this area was directed toward coal-fired boilers where most of the problems occurred. In recent years, however, additional attention has been focused on heat-recovery systems because rising energy costs have provided significant incentives to recover energy from exhaust gas streams in a wide spectrum of industries which use a variety of fuels.

Fouling may be defined as the deposition of an insulating layer of material onto a heat-transfer surface which retards the flow of heat. When the deposition results as a consequence of a dirty gas stream coming in contact with a surface, the fouling process is referred to as gas-side fouling. In many cases the combustion gases, including those from clean burning fuels, can become badly contaminated with particulate matter and condensable gaseous species because of specific industrial processes which the gases undergo. Such process contamination -- which tends to increase the gas-side fouling and corrosion potential -- occurs widely in the fooustuffs, petrochemical, cement, glass, iron and steel, aluminum, and copper industries. Finally, it should be pointed out that gas-side fouling can be a problem in direct heating applications, such as those in industrial boilers, as well as in heat recovery systems.

The following classification scheme for fouling has become widely accepted:

(a) Precipitation Fouling - the precipitation of dissolved substances onto the heat transfer surface. Where the dissolved substances have inverse rather than normal solubility versus temperature characteristics, the precipitation occurs on superheated rather than subcooled surfaces. and the process is often referred to as scaling. 
(b) Particulate Fouling - the accumulation of finely divided solids suspended in the process fluid onto the heat transfer surface. In a minority of instances settling by gravity prevails, and the process may then be referred to as sedimentation fouling.

(c) Chemical Reaction Fouling - deposits formed at the heat transfer. surface by chemical reactions in which the surface material itself is not a reactant.

(d) Corrosion Fouling - the heat transfer surface itself reacts to .... produce corrosion products which foul the surface and may promote-the attachment of other foulants.

(e) brological fouling - the attachment of macro-organisms (macro-fouling) and/or micro-organisms (micro-biofouling or microbial fouling' to a 'heat tiransfer surface, aluing with lhe dulleremb bimes often generated by the latter.

(f) Solidification Fouling - freezing of a liquid or somé of its higher melting. constituents onto a subcooled heat transfer surface.

Of these six categories, all but crystallization fouling can occur in gas-side fouling. Particulate fouling is most likely to be assucidted with gas-side fouling but chemical reaction fouling, corrosion fouling, and solidification can also be important.

Under sponsorship of the U.S. Department of Energy (DOE) Assistant Secretary for Conservation and Renewable Energy, particularly the Energy Conversion and Utilization Technology (ECUT) Program, several studies in the area of gas-side fouling have been conducted. This effort includes: characterization of Diesel exhaust gases and experimental studies of gas-side fouling and corrosion in Diesel exhausts (References 1-8), an assessment of gas-side fouling in glass plants (References 9-11), an assessment of gas-side fouling in cement plants (Reference 12), gas-side fouling and corrosion operating experience with an organic Rankine cycle bottoming system (References 
13-15), the use of fluidized bed heat recovery systems to mitigate the effects of gas-side fouling (References 16-19), an assessment of plastic heat exchangers for use where acid and water condensation are serious problems (Reference 20), and a workshop on the assessment of gas-side fouling in a variety of fossil fuel exhaust environments (References 21-22) including the formulation of a categorized bibliography on gas-side fouling (Reference 23).

At the Gas-Side Fouling Workshop (References 21-22), forty-one participants made several recommendations for R\&D projects in the area of gas-side fouling. Their high-priority recommendations include the following seven items:

- Characterization of Fossil Fuel Exhaust Gases

- Development of a Gas-Side Fouling Measuring Device

- A Study of Attachment and Removal Mechanisms and Formulation: of Gas-Side Fouling Predictive Methods

- Collection of Empirical Gas-Side Fouling Data for Specific Geometries

- Effectiveness of Various Cleaning Devices for Gas-Side Fouling Service

- The Mechanism of Wet Wall Fouling in Fossil Fuel Exhaust Gases

- Alternative Types of Heat Exchange Equipment to Enhance Heat Transfer and to Mitigate the Effects of Gas-Side Fouling

The first three recommendations are closely related; in fact, the development of a sultable gas-side fouling measuring device is a prerequisite t.n carrying out basic studies of attachment and removal mechanisms and, ultimately, the formulation of methods to predict gas-side fouling processes.

Specifically, among the workshop participants (Reference 21)

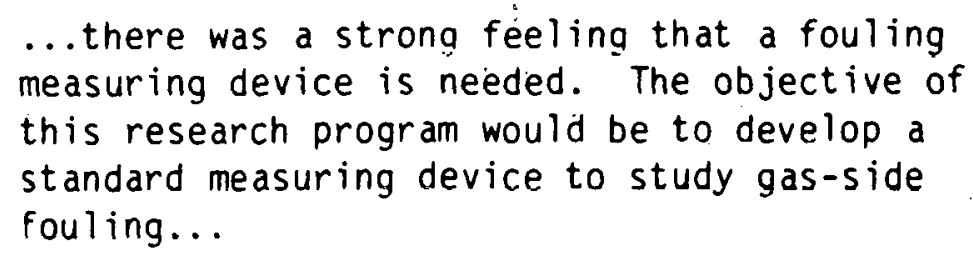


Based on: (a) the recommendations made at the workshop, (b) the importance of such a device in carrying out additional workshop recommendations, and (c) . the available ECUT Program financial resources; the DOE ECUT Program sponsored a survey to define the state-of-the-art for gas-side fouling measuring devices.

$\because \quad$ This suurvey was undertaken jointly by the Jet Propulsion Laboratory, $\because$ California Institute of Technology (JPL) and EG\&G Iaaho,. Inc. In order to* obtain the required information, an extensive computerized literature search was carried out. Additional information. was also obtained through personal . contacts; telephone calls, letters, plant visits including a trip to the United $\because \quad$ Kingdom by one of the authors (S.P.H), and attendance at professional meetings. $\because$ Finally, the Battelle bibliography. on "Corrosion and Deposits from. Combust ion. $\therefore$ Gases" (Reference.24), proved to be a. valuable source of information. 
SECTION 2

CLASSIFICATION OF GAS-SIDE FOULING MEASURING DEVICES

Fischer, Suitor, and Ritter (Reference 25) and Knudsen (Reference 26) have presented review articles which discuss fouling measuring devices suitable for use in liquid systems. However, many of these devices utilize electrical heating. to provide a heat flux to the fluid and hence are not suitable for use in making gas-side fouling measurements. In applications involving combustion gases, which are of principle interest here, heat is transferred from the hot gases to a process fluid and hence the gas is always cooled, either in a direct heating application or in a heat recovery system. Gas-side fouling measuring devices, or probes, have been used in a number of industrial applications including: industrial and utility boilers, municipal incinerators, gas turbine applications, and heat recovery systems in a broad range of industries. In addition, a number of studies utilizing gas-side fouling probes have been carried out in laboratory settings.

A variety of devices have been used to obtain and analyze gas-side fouling deposits. These devices range from a small cylindrical disc to a full-size heat exchanger, with a number of intermediate varieties. For purposes of the present study, test sections with more than a single probe were excluded from consideration unless at least one of the tubes was individually instrumented. However, U-tube modules and devices using more than one tube in order to simulate the maximum gas velocities obtained in a tube bundle are included, provided that the criterion established above is satisfied. As might be expected, most of the probes are single, circular cylinders which utilize a controlled surface temperature maintained by air or water flowing through the inner portion of the devices. Although all of the probes are capable of collecting gas-side fouling deposits, it is quite surprising that very few of them are capable of measuring gas-side fouling resistances.

Although gas-side fouling measuring devices come in a variety of sizes and shapes, each of them may be grouped in one of the five following categories: 
(a) Heat Flux Meters

(b) Mass Accumulation Probes

(c) Optical Devices

(d) Deposition Probes

(e) Acid Condensation Probes.

The essential features of each of these types of probes will be considered briefly.

As the name implies, a heat flux meter measures the local heat transfer per unit area to monitor the fouling resistance. The decrease in heat flux as a tunction of time is thus a measure of the fouling buildup on the heat transfer surface. Most of the heat flux work to date has been related to furnace applications where radiation is the dominant mode of heat transfer. However, there is no conceptual reason why this approach could not also be used in those applications, such as heat recovery systems, where heat is transferred primarily by convection.

A mass accumulation measuring device is a probe which has been designed so that the deposit sample mass may be determined quantitatively, generally under controlled conditions of the surface temperature, gas temperature, and other. parameters of interest. In a number of cases where the interaction of fouling and corrosion occurs simultaneously, this type of probe has been used to measure corrosion rates as well. In the case of the corrosion-type mass deposition probe, it has been common practice to use cylinders consisting of many segments joined together by threads, tension. or some other means.

Optical fouling measuring devices are those used to determine deposition rates using optical methods. Such devices have been used on a very limited basis and to date have been restricted to relatively simple laboratory studies under very controlled conditions.

Deposition measuring devices are probes which are used to collect deposits, generally under controlled conditions, on a qualitative basis. In this type of device, the actual mass of the deposit is not determined; however, 
quantitative analyses of the deposit itself -- irrespective of the magnitude of the mass -- are frequently carried out. In many cases multi-segmented corrosion probes are of the deposition type.

Finally, acid condensation probes are used to collect liquid acid which accumulates on a surface which is at a temperature below the acid dew-point of the gas stream. Such probes are frequently used to measure dew-point temperatures as well as acid deposition rates. A number of probes of this type are available commercially and therefore, since a solid fouling deposit does not occur when acid alone is being condensed on the heat transfer surface, secondary importance has been given to this type of probe. However, because of the importance of the water and acid dew-point condensation problem in low temperature heat recovery applications; the acid condensation probe is also included here.

“. Thus, although five types of gas -side fouling measuring devices, or probes, have been identified -- and although each of these will be discussed in some detail -- the major emphasis in this report is placed on mass accumulation and deposition type probes. Of those gas-side fouling probes suitable for insertion into industrial gas streams, including those which are process contaminated, it is apparent that the present state of the art is focused on these two types of measuring devices.

$2-3$ 


\section{SECTION 3}

STATE-OF-THE-ART REVIEW OF EXISTING GAS-SIDE FOULING MEASURING DEVICES

The purpose of the present section is to review the current state of the art for measuring devices used in gas-side fouling applications. Each of the five types of devices defined in Section 2 will be reviewed with appropriate details, including references, on the probes which have been developed to date. Figures are included wherever possible to help describe these instruments. The major emphasis is placed on the actual operating experience which the various probes have undergone. This section will conclude with a special consideration of the information obtained during a visit to the United Kingdom, where a considerable amount of gas-side fouling work, including the development and use of fouling probes, has been carried out.

For a specific type of device, the probe geometry, the material(s) of construction, and the conditions under which the probe was tested are all of interest. In many cases the wall temperature of the probe is maintained at a specified level by varying the mass flowrate of a secondary fluid such as air or water which is used to cool the probe. The control system used to achieve this objective is discussed where appropriate. The measurement of heat flux, on both the primary and secondary sides of the probe, is an important consideration. Gas-side velocity, turbulence intensity, and temperature -- as well as the probe wall temperature -- are all important parameters in gas-side fouling and consideration is given to these topics. The maximum sampling period, or time which the probe is exposed to the combustion gases, gives some indication as to the robustness of the device. Finaliy, a device may have unique capabilities and these attributes are discussed where applicable.

In addition to the probe per se, some atcention is also devoted to two related aspects. The first of these is the characterization of the gases to which the probe is exposed. Such items as fuel analysis, qaseous components, dew-point temperatures of the condensible components, particle size distribution, particle composition, particle concentration and excess air are 
all important parameters in the gas-side fouling process. Therefore, a knowledge of these parameters is almost indispensable in analyzing the results obtained from the gas-side fouling probes. The second topic which is also of interest is that of deposit analysis. This category includes such items as: deposit constituents, deposit morphology (structure and characteristics), deposit melting temperature, corrosion analysis, and the magnitude of the deposit mass. The accuracy of the deposit mass is an important consideration in establishing fouling deposition rates. Finally, the diagnostic techniques used to determine the gas characterization and deposit analysis parameters are also of some interest.

\subsection{HEAT FLUX METERS}

Heat flux meters arc discussed in this section. These devices have been used primarily in furnaces where radiation is the dominant mode of heat transfer. However, in principle this type of instrument could also be adapted for use where the dominant mode of heat transfer is convection. The design details and operating experience of several heat flux meters are presented.

\section{Central Electricity Research Laboratories, United Kingdom}

Northover and Hitchcock (Reference 27) developed a heat flux meter which employs the radial disc principle as shown in Fig. 3-1. Heat flowing into the disc is distributed radially and then conducted to the boiler tube through the meter body. The finite thermal resistance of the disc gives rise to a temperature difference between the disc center and its periphery which is attached to the meter body. The connecting wires attached at these two locations sense the emf produced which is proportional to the radial temperature difference and hence the heat flux. Initial boiler trials indicated that the most satisfactory body material was British Oriver Harris 02 and Corronel 230 for the disc material. It was also found that the meter cavity should be filled with an inert gas to minimize corrosion of the two connecting wires. Prototype meters of the type shown in Fig. 3-2 were constructed, with the heat flux meter mounted on the boiler tube as shown. The cable shield was curved to fit around the outside of the boiler tube and welded 


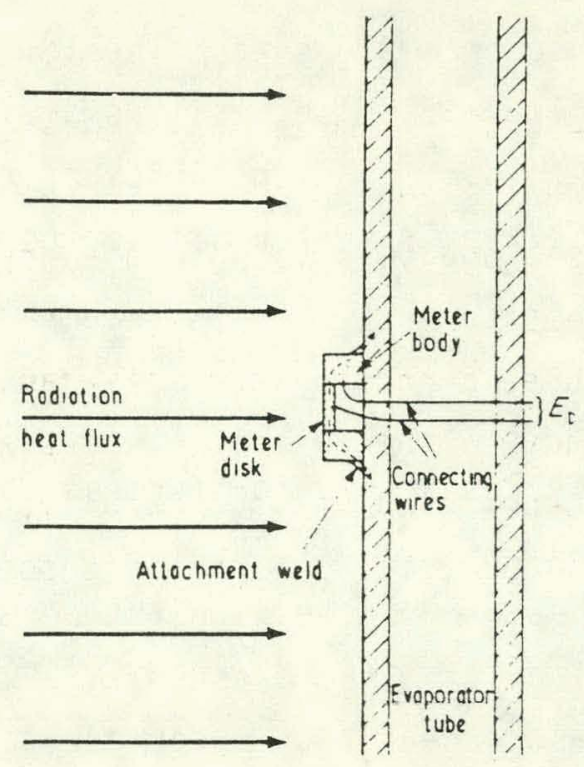

.... Heot poth throught meter

Figure 3-1. Basic Principle of the Heat Flux Meter (Reference 27)
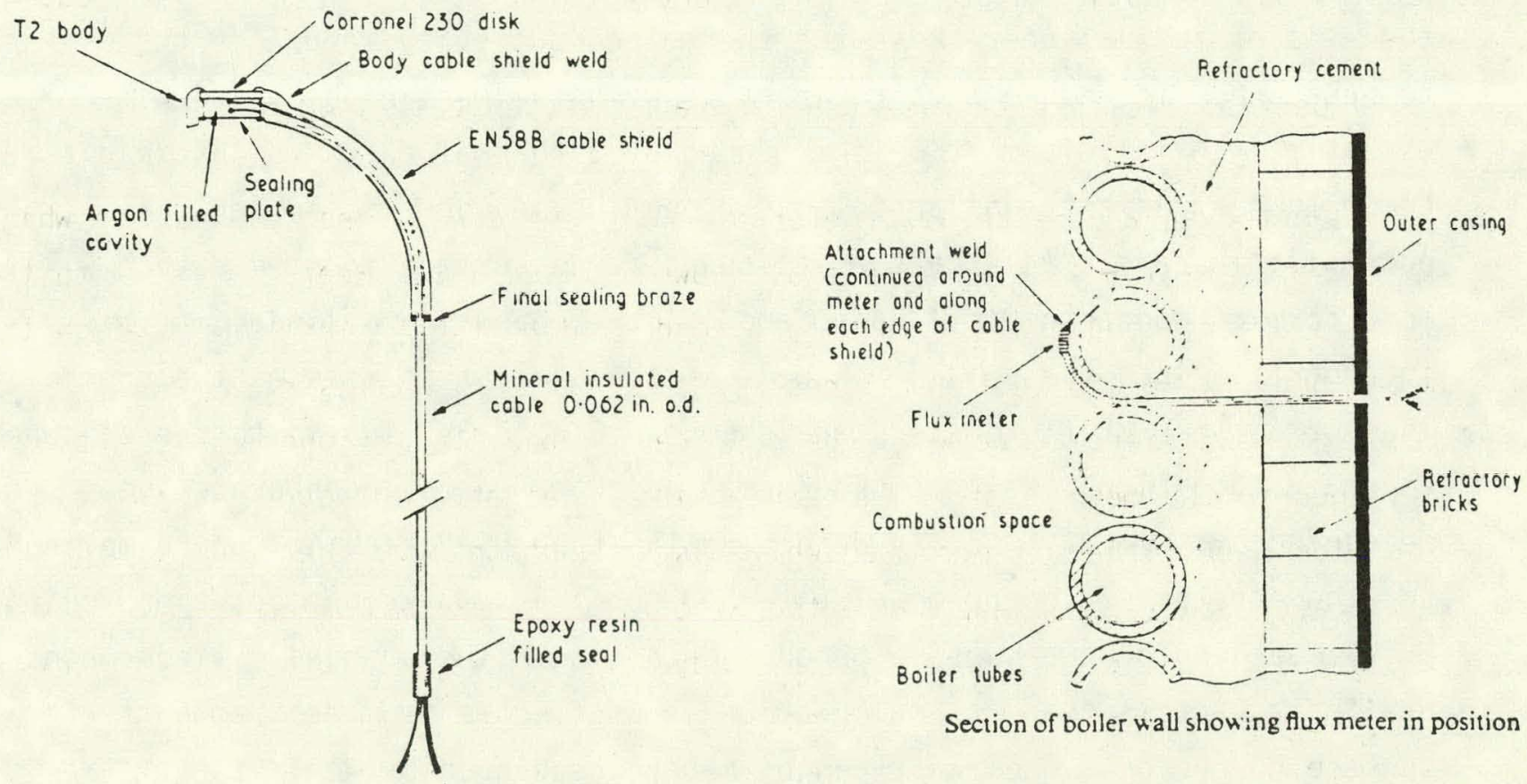

Section of disk heat flux meter

Figure 3-2. Disc-Type Flux Meter Developed by Northover and Hitchcock (Reference 27) 
to the edge of the body to form a gas-tight seal. Argon was the inert gas chosen to fill the meter cavity which was then sealed around the cable shield entry point with silver solder. The integrity of the meter was finally proved by a pressure test. This type of meter was tested satisfactorily under severe conditions in an oil-fired boiler for over 200 days without any deterioration in performance.

\section{Central Electricity Research Laboratories, United Kingdom}

In order to have heat flux meters which operate at heat fluxes up to 222,000 Btu/hr-ft², Neal et al. (References 28-29) developed two permanently installed devices to mcasurc heat flux under ash fouling conditions. The lsas is for these devices is the guarded cylinder technique. This method makes use of the temperature qradient qenerated along a cylinder of known thermal conductivity when heat is applied to one end while the other end is connected to a heat sink. The axial temperature gradient is measured using thermocouples at a known spacing along the cylinder. The wall heat flux is then calculated using Fourier's law, $q_{w}^{\prime \prime}=-k d T / d z$, where $z$ is the spatial coordinate along the axis of the cylinder, $k$ is the thermal conductivity, and $T$ is the temperature. To ensure that the heat flow in the measuring cylinder is essentially axial, it must be surrounded by a thermal guard which exhibits a temperature gradient similar to that along the measuring cylinder. Two possibilities are: (a) the thermal guard for a surface mounted device will be some form of concentric cylinder, and (b) the measuring cylinder may be incorporated into the boiler tubewall which itself then acts as the guard. These two types of flux meters are shown in Fig. 3-3. In the thickened tube approach, additional wall thickness may be obtained to incorporate the measuring cylinder by locally deforming the tube by "crankina" or "dimpling" and then restoring the original external profile by a weld deposition, followed by a smoothing of the surface through machining. The quarded cylinder concept has the advantage that its calibration is unaffected by modest amounts of surface corrosion. The two types of meters developed by Neal et al. (References 28-29) are based on these two concepts and are called, respectively: (a) the Fluxtube, and (b) the Dometer. Each of these devices will be discussed briefly. 
The Fluxtube is shown in Fig. 3-4 and is based on the thickened tube concept. In addition to the heat flux, this instrument is also designed to measure tubewall temperature and the tubeside fluid (water/steam) temperature. It is made from a short length of boiler tube containing a locally thickened wall section incorporating a measuring cylinder created by either "cranking" or by "dimpling", followed by a weld deposition and then machining of the surface. Both the measuring cylinder and weld deposit are made of 1.0 percent chromium and 0.5 percent molybdenum steel. The thermocouples are nickel-chromium/copper-nickel and the hot junction ends are secured in the holes with a copper-based cement. Additional constructional details of the Fluxtube may be noted in Fig. 3-4. Neal et al. (Reference 29) claim an accuracy in heat flux measurements within \pm 5 percent.

The Dometer, so-called because of its dome-shaped profile in its installed position, is a boiler tube surface-mounted device. The basic design of this instrument is shown in Fig. 3-5. It is fabricated from stainless steel with the same type of thermocouples as used in the Fluxtube. The Dometer is welded to the boiler surface as indicated and the junctions are spaced approximately $0.12 \mathrm{in.}$ apart. The core cylinder, separated by an air gap, is $0.24 \mathrm{in}$. in diameter. A theoretical study was carried out to investigate the effects of core, air gap, and guard configurations and the calibration of the device when covered with ash.

A total of five Fluxtubes and 21 Dometers were installed in a localized high-flux region of an oil-fired power station boiler and an additional nine Dometers were installed in a coal-fired boiler in a region of appreciable slagging. Measured heat fluxes ranged from about 12,700 to slightly over 190,000 Btu/hr-ft2. The oil-fired boiler trial was terminated after 10,000 hr of firing but there were periods of intermittent stoppage. As might be expected, fluctuations in the coal-fired boilers were much greater (typically \pm 10 percent). The agreement between the Dometer and Fluxtube measurements was generally within \pm 10 percent. 

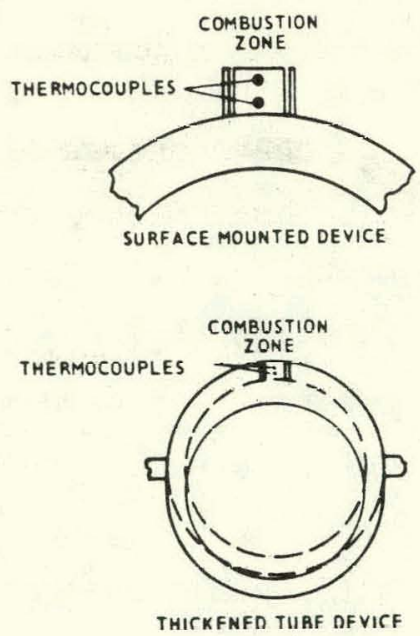

Fiqure 3-3. The Two Types of Boiler Tulu Heat Flux Measuring Cevices (Reference 28)

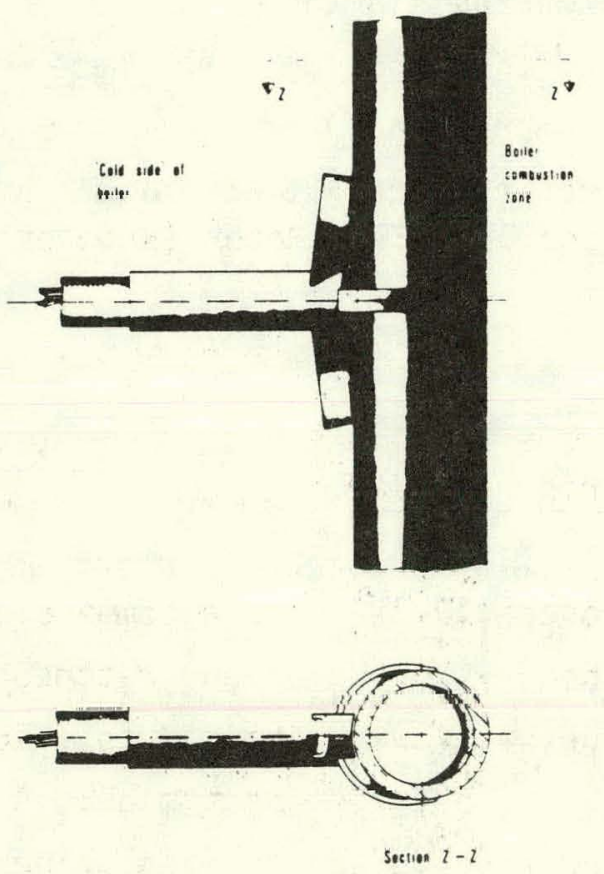

'CRANKEO' FLUXTUBE

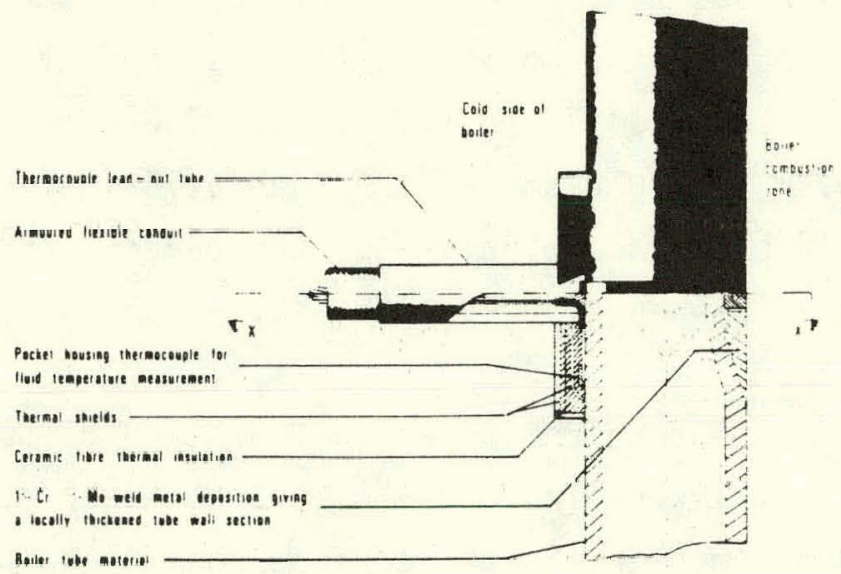

Pa: sectioe $r-y$

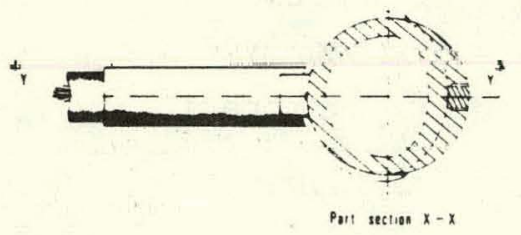

'DIMPLEO' FLUXTUBE

Figure 3-4. Cranked and Dimpled Versions of the Central Electricity Research Laboratories Fluxtube (Reference 29) 


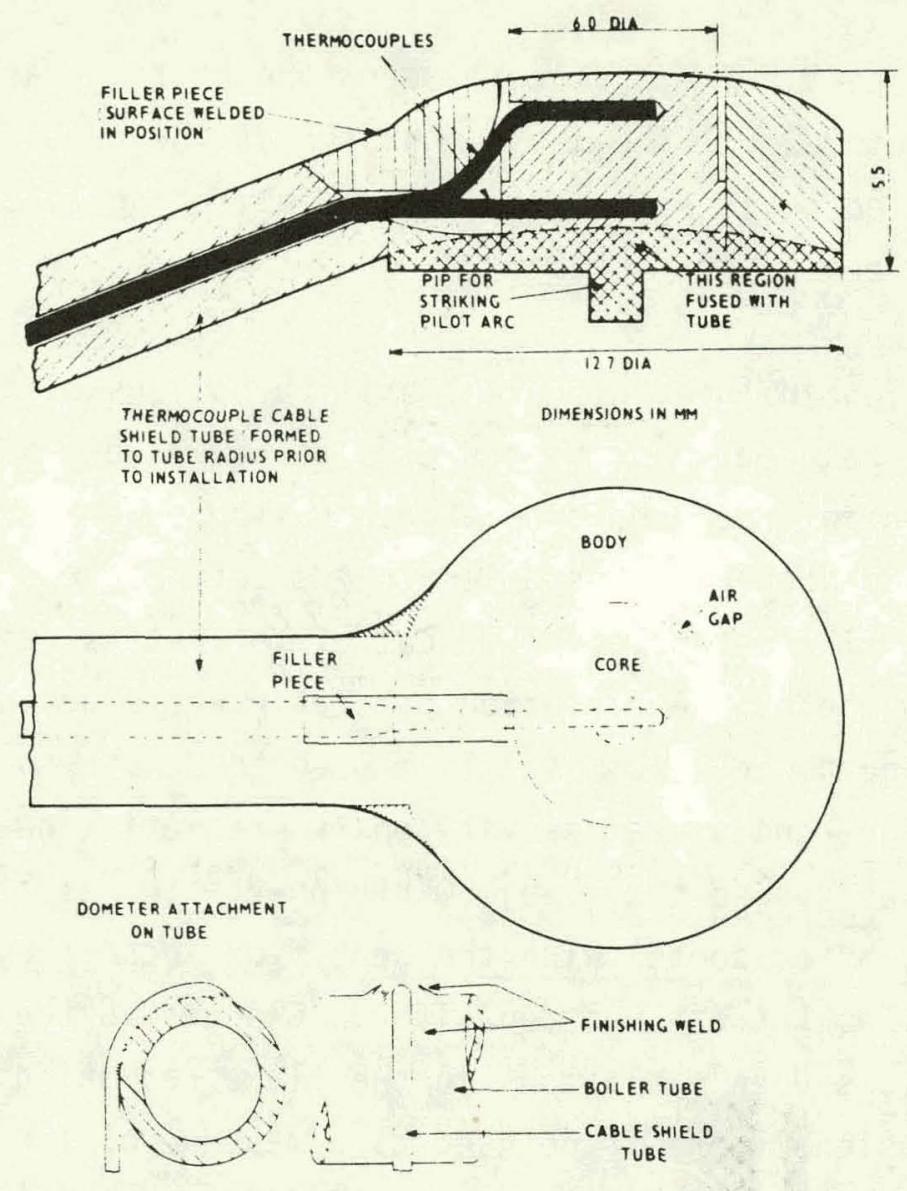

Figure 3-5. Detail Design of the CERL Dometer Heat Flux Meter (Reference 29)

University of Water 100 , Waterloo, Ontario, Canada

Chambers, Wynnyckyj, and Rhodes (References 30-31) used a commercially available disc-type meter of the type described by Northover and Hitchcock (Reference 27) previously. A second disc-type meter was attached to a copper heat sink which in turn was attached to a 5/8-in.-diameter heat pipe. A small finned tube heat exchanger mounted to the condenser end of the heat pipe was used to cool the heat pipe with air. An envelope of air flowing in the annular region between the copper heat sink and the outer housing of the probe provided an air jet which continually prevented ash from depositing onto the heat flux meter surface. Calibrations showed that the air jet reduced the heat flux by 
less than five percent. The surface temperature of the heat flux meter was maintained at about $392 \mathrm{~F}$. Thus, a comparison of the heat flux as measured by the clean and fouled devices gave a relative indication as to the amount of ash deposition on the boiler surfaces.

Ash deposition in three different utility boilers was studied rather extensively. Several heat flux meters were installed on the water walls in the combustion chamber in areas where heavy ash buildups were anticipated. Aircleaned heat flux probes were installed in inspection ports adjacent to the wall-mounted heat flux meters. The output of the meters was monitored over a period of several months. A radiation pyrometer was used to monitor changes in the flame radiating power which is a term used to denote the combined effects of flame temperature and gas emissivity on the radiative heat flux to the water walls. Heat fluxes ranged from $159,000 \mathrm{Btu} / \mathrm{hr}-\mathrm{ft} \mathrm{f}^{2}$ to less than 15,900 Btu/hr-ft? , i.e., after sootblowing the heat flux increased significantly but then fell sharply as the ash was deposited. Changes in the clean meter heat fluxes were due to sudden variations in the flame radiating power. Thus, if the fouled meter signal were to be used as a measure of ash deposition only, there was a need for a direct measurement of flame radiating power which could be affected by many variables such as coal composition, excess air, burner setting, and ash cleaning in other areas of the boiler. Initially a radiation pyrometer was used to monitor changes in the flame-radiating power. However, because of the ease of signal conditioning, an air-rleaned heat flux meter probe was found preferable tor this purpose. However, the signals from the clean and fouled heat flux meters were in general not equal because of the fact that the two meters were in different locations. Also, in subtracting the signals from the two meters electrically, there was a relatively large common mode voltage (apparently due to a thermal emf generated hy the jet nf the heat flux meter and the boiler tube). By means of an adjustable amplifier gain, the "F" factor applied to the clean meter was adjusted to give a zero system output when both flux meters were in a clean state.

It should be emphasized that the ash monitoring system described does not give a direct measure of ash thickness even though it does give an indication of the heat flux. At the time the paper was published, additional mathematical 
modeling was being undertaken to predict the deposit thickness from the measured heat flux and physical properties of the ash deposits. Although additional work is needed to clarify this method, it is evident that this approach will be useful in monitoring the buildup of ash deposits in coal and oil-fired boilers where radiation is the dominant mode of heat transfer. What is not clear is how applicable this approach is to those situations in which convection is the controlling heat transfer mode.

\subsection{MASS ACCUMULATION PROBES}

The next category of devices to be considered is the mass accumulation probe. One of the major objectives of this type of instrument is the measurement of the deposit mass collected on the probe. In turn, the mass deposition rate as a function of surface temperature and other parameters of interest may be determined. A variety of devices of this type have been designed, constructed, and tested in a wide range of environments.

\section{University of Sheffield, United Kingdom}

Brown, et al. (References 32-33) studied the deposition of sodium sulfate and vanadium pentoxide using a pilot scale furnace. This work was carried out in the Department of Fuel Technology and Chemical Engineering at the University of Sheffield in the United Kingdom. The probe used in these studies is shown in Fig. 3-6 and was nominally $3 \mathrm{ft}$ long and $1 \mathrm{in}$. in diameter. It consisted of several specimens or segments, each with a Pyrotenax thermocouple embedded in the segment to measure the wall temperature. By varying the air flow down the center of the probe, the surface temperature was controlled in the range of 752 to $1364 \mathrm{~F}$ during the tests. Deposits were produced by exposing clean, weighed segments of stainless steel in the combustion gases for up to $10 \mathrm{hr}$. The fuel used was kerosene doped with sodium napthenate and carbon disulfide to obtain sodium sulfate, and kerosene doped with vanadium ethyl hexoate to obtain vanadium pentoxide. In addition to gas temperature, velocity, and composition, Brown et al. also measured the turbulence intensity of the gas in these studies. Deposits were obtained at two excess air levels -- less than 1.0 percent and 25 percent. By weighing the segments before and after deposition (there was no corrosion), the amount of mass deposited was readily determined. In these tests the amount of mass deposited was quit.p small, ranging frnm $\cap . \cap n 97$ t $\cap \cap . \cap 2 ? 4 \mathrm{~g}$. 


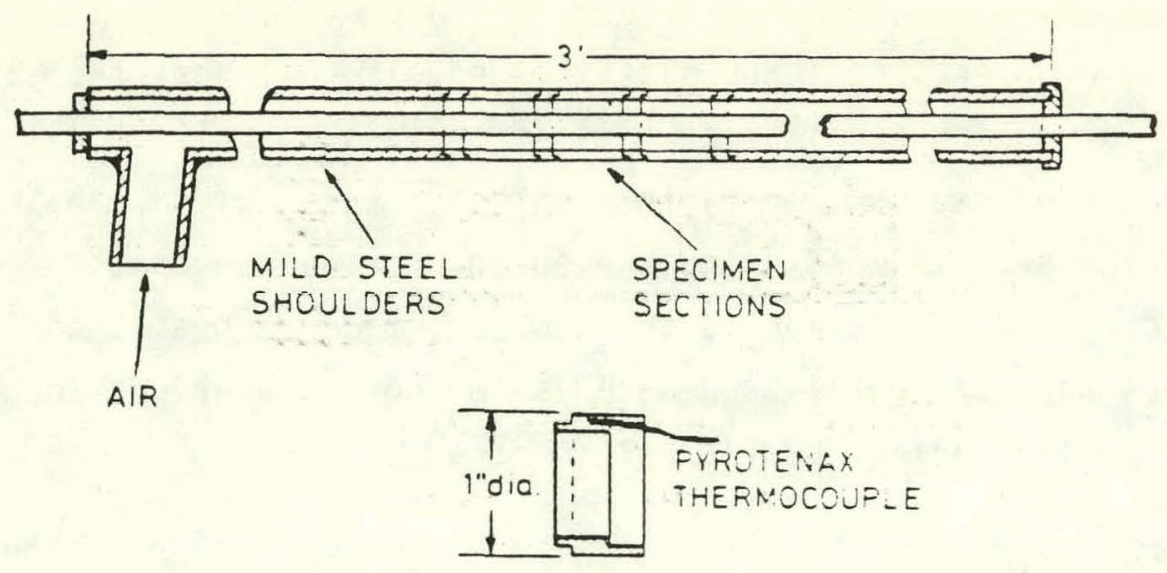

Figure 3-6. Air-Cooled Mass Accumulation Probe Developed by Brown, et al. at the University of Sheffield (References 32-33)

In addition to the $\mathrm{Na}_{2} \mathrm{SO}_{4}$ and $\mathrm{V}_{2} \mathrm{O}_{5}$ dew-point temperatures, Brown, et al. also determined the deposition rates as a function of surface temperature and compared their results with those obtained using a vapor diffusion model. They found very good agreement between the experimental results and theoretical predictions near the dew-point temperature; however, as the probe surface temperature was reduced, the experimental deposition rates were found to fall far below the predicted values. Brown, et al. explained. this lack of agreement by noting that the condensed liquid droplets would tend to solidify near a cold surface, thus reducing the tendency of the particles to adhere to the surface.

\section{Rheinisch-Westfallisches Elektrizitatswerk $A G$, West Germany}

Hein (Reference 34) reported on gas-side fouling studies using Rheinisch brown coals at the Rheinisch-Westfallisches Elektrizitatswerk AG (RWE) in the federal Kepublic of Germany. The research rig consisted of a roof-fired, steam-cooled, 3.94-ft diameter combustion chamber designed for a maximum brown codl throughput of $11001 \mathrm{~b}_{\mathrm{m}} / \mathrm{hr}$. The probe used in this study is shown in Fig. 3-7. It consists of a water-cooled extension and an air-cooled probe head. The probe head includes both a 1.97-in. long air-cooled surface and a 1.97-in. long uncooled surface made of ceramic, the latter to simulate a tube which had already been fouled. The probe head is $1.34 \mathrm{in.}$ in diameter. The temperature of the air-cooled surface was measured by means of a wall thermocouple and controlled by varying the air flowrate through that portion of 


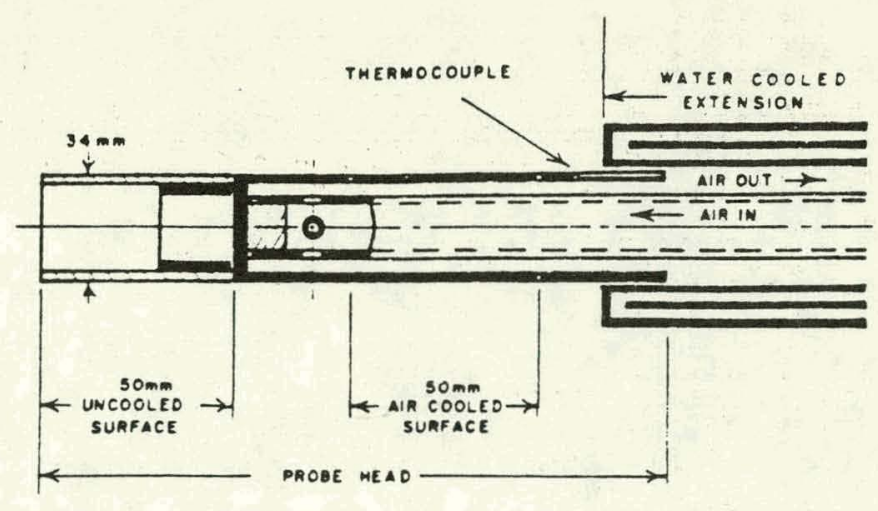

Figure 3-7. RWE Mass Accumulation Probe, Hein (Reference 34)

the probe head. Auxiliary equipment available to analyze the deposits included a laboratory for wet chemical analysis of the coal, fly ash, and deposit samples, an X-ray fluorescence analyzer, and an X-ray diffraction analyzer. Parameters studied, at least to some extent, included excess air ( 0 to 50 percent), mixing of fuel and combustion air, particle size distribution of the incoming coal, and combustion air temperature. Results were reported for tests up to durations of $60 \mathrm{hr}$. Gas temperatures during the tests conducted were about $1650 \mathrm{~F}$ with wall temperatures ranging from 1112 to $1472 \mathrm{~F}$.

\section{David W. Taylor Naval Ship R\&D Center, Bethesda, Maryland}

Rogalski (References 35-36) reported test results involving the insertion of a cooled cylindrical fouling probe in a shipboard LM 2500 gas turbine exhaust stream and a land-based Solar Saturn gas turbine exhaust. This work was carried out by the David W. Taylor Naval Ship Research and Development Center through support provided by the Naval Sea Systems Command. The test unit probe was a heat pipe device cooled by ambient air and instrumented to measure the heat flux and also the gas-side fouling resistance. The unit was designed so that the evaporator end of the heat pipe, which had a 4-in. active probe length, was exposed to gas turbine exhaust gases while the condenser end was cooled by air flowing through a calibrated orifice. A schematic drawing of the cylindrical fouling probe test unit is shown in Fig. 3-8. 


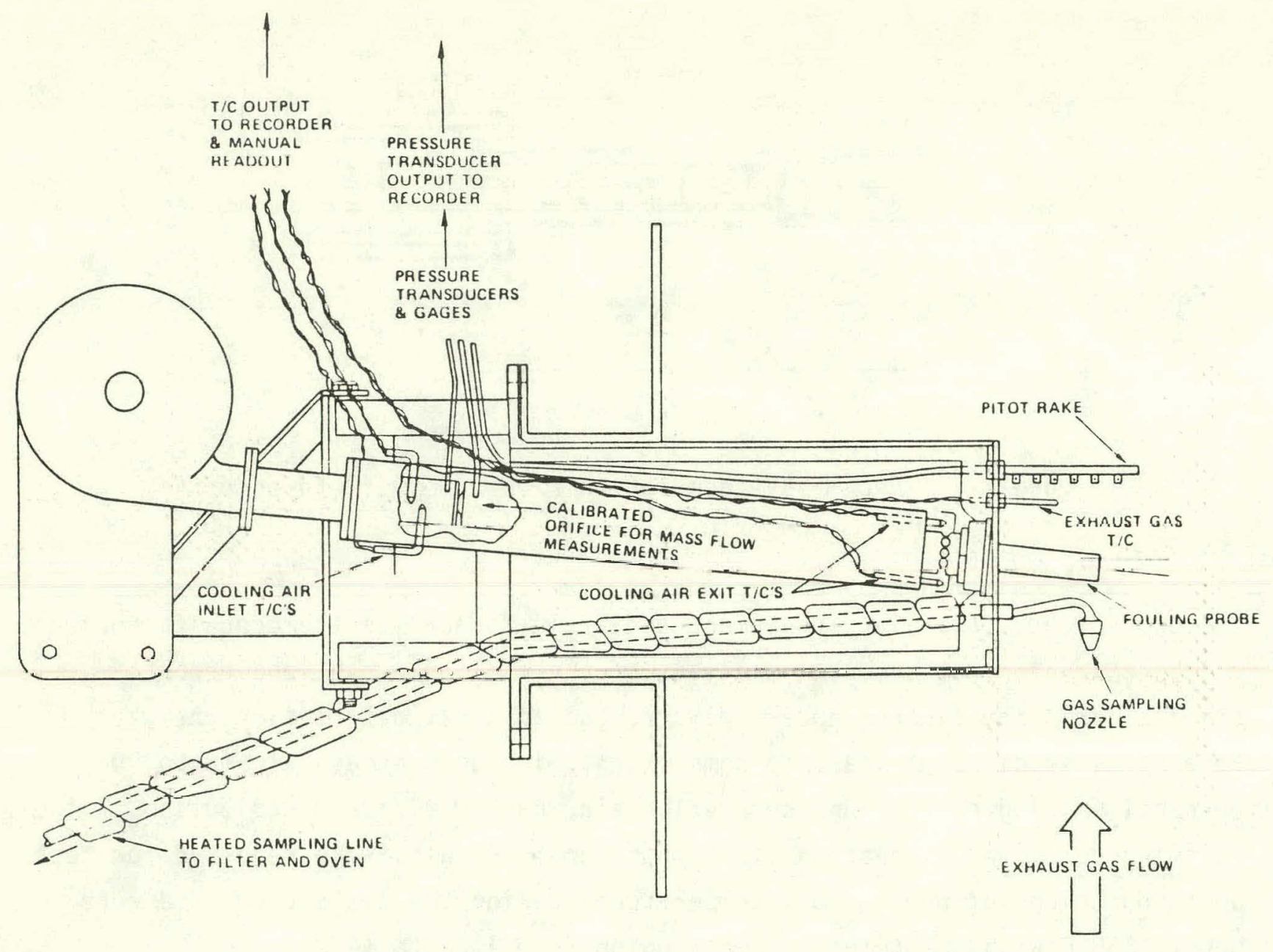

Figure 3-8. David Taylor R\&D Center Heat Pipe Mass Accumulation Probe (References 35-36)

A stainless steel heat pipe was used for rapid heat transfer from the exhaust qases at the bare cylindrical hot end to the finned condenser end cooled by air from a blower. The blower, which supplied cooling air to the probe, was requlated so that for a given exhaust gas temperature, a range of probe wall temperatures was achieved on the fouled portion of the probe. The heat transter was determined by measuring the inlet and outlet air temperatures of the cooling air as well as the mass flowrate of the cooling air. A deterioration of the overall heat transfer coefficient with time was thus used as an indication of the magnitude of the gas-side fouling resistance. Exhaust gas velocity was determined using a pitot tube in the vicinity of the fouling probe. Thermocouples were used to measure both the exhaust gas and probe 
wall temperatures. Exhaust gas particulate measurements were made near the fouling probe location by using an EPA Method 5 sampling train which was designed to allow isokinetic sampling.' Following each test, the accumulated fouling deposit thickness was measured using an optical comparator. Deposit samples, taken following each fouling test, and filtered. particulate samples were analyzed using X-ray fluorescence which produces an elemental analysis of the sample. Test fuel samples. were analyzed for metals using a fluid analysis spectrometer. Tests of up.to $114 \mathrm{hr}$ duration were carried out with gas temperatures of 522 to $922 \mathrm{~F}$, probe surface temperatures of 145 to $715 \mathrm{~F}$, and gas velocities of 43 to $450 \mathrm{ft} / \mathrm{sec}$. For the shipboard tests the gas-side fouling resistances reached maximum values of four times the Tubular Exchanger Manufactures Association. (TEMA) recommended values during time periods of 70 to $90 \mathrm{hr}$ (References 35-36).

\section{Boris Kidrich Institute for Nuclear Sciences, Vinca, Yugoslavia}

Oka, Kostic, and Repic (Reference 37) developed a probe (referred to as a sonde. in their paper) for determining the ash deposit formation from low-rank coals. This work represents a portion of the ongoing effort at the Institute for Thermal Engineering and Energy Research at the Boris Kidrich Institute for Nuclear Sciences in Vinca, Yugoslavia. The studies were carried out using an experimental furnace and auxiliary systems which included a tubular furnace, pulverized coal preparation and feeding line, air preparation and feeding line; and a flue gas line. The cylindrical gas-side fouling probe is shown in Fig. 3-9. Both ends of the probe are water cooled with the section exposed to the combustion gascs held at a constant surfare temperature ranging from 842 to $1040 \mathrm{~F}$ by cooling air. This portion of the probe is equipped with a wall thermocouple and a heat flux meter so that both the surface temperature and heat flux can be measured at the location where the ash deposit takes place. The probe length and diameter were not given in the paper. Additional instrumentation was available for taking particle and gas samples, measuring gas velocity and gas temperature, analyzing the coal and the ash, analyzing the deposits, and measuring the melting temperature of the deposits. Initial experimental results have included: (a) investigation of the pulverized coal combustion, and (b) investigation of the ash formation process. Further 


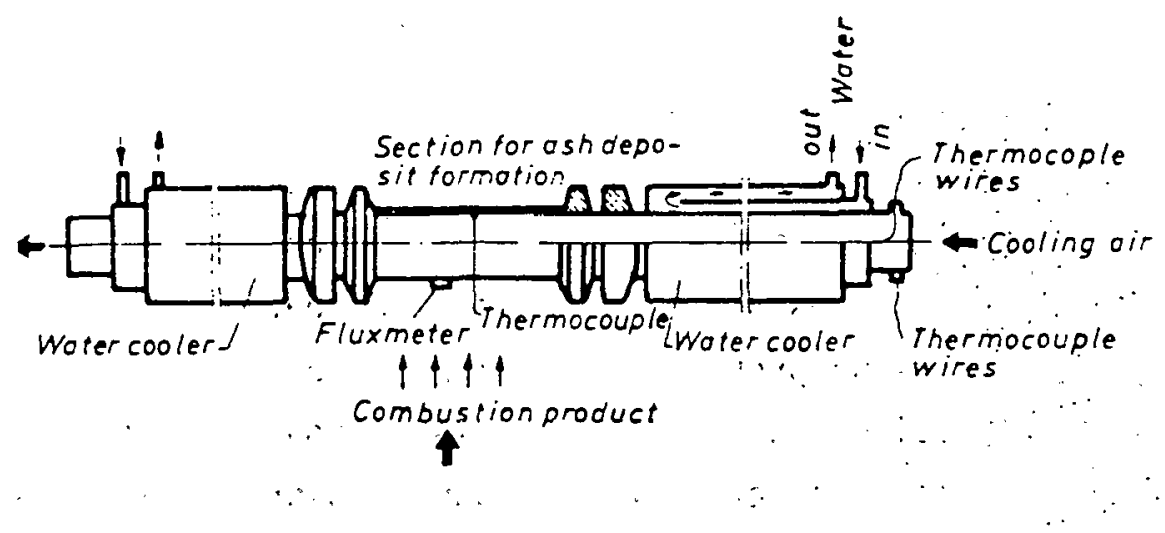

Figure 3-9. Mass Accumulation Probe Developed at the Boris Kidrich Instituite, Yugoslavia (Reference 37)

expcriments are planned to delermine the effect of the following parameters: coal composition, temperature of primary air, excess air, coal moisture, and, volumetric heat release. Results obtained, and included in graphical form in.. the paper include oranulometric composition of the coal, surface temperature of the probe, and the amount of excess air. (20 to 50 percent).

Exxon Research and Development Company, Baytown, Texas

Lin and winegartner (Reference 38) reported on efforts to.carry out the fouling of probes in the combustion products of a variety of coals. These studies were carried out at the Exxon R\&D Company in Baytown, Texas, in their Solid Fuel Evaluation Unit (SFEU). The coals tested included spveral ranks of coal from various parts of the world. Hot combustion products leave the furnace through a refractory-lined spool which simulates the superheater and reheater sections of a utility boiler. Two gas-side fouling probes are inserted separately into, the refractory-lined spool sertion underneath the combustor. Each cylindrical probe is 0.75-in. OD with 304 stainless steel as the wall material. A Chromel-Alumel thermocouple is welded to the inner tube in order to measure the probe wall temperature. To prevent cooling air from entering the untt, the end of the probe tube is closed. A 0.25-in.-OD stainless steel tube is inserted into the open end of the probe and an air.flow is passed through this tube and out through the annular space between the two tubes. The upper probe was maintained at a metal temperature of about $1000 \mathrm{~F}$ and the lower probe was not cooled. The gas temperatures ranged from about 1300 to $2000 \mathrm{~F}$ during the tests conducted. Coals from Canada, Australia, 
Poland, and South Africa -- as well as 11 different coals from the U.S. -- were tested in a 16-percent excess-air environmerit with flue gas velocities of about $15 \mathrm{ft} / \mathrm{sec}$. The deposits collected were quite small, ranging from about 0.2 $5.0 \mathrm{~g}$. Extensive fuel analyses were carried out for each type of coal tested. The deposits collected on the probes were analyzed and the results compared favorably with those obtained at the Grand Forks Energy Research Center (GFERC) in North Dakota, which in turn were known to agree favorably with results from commercial experience.

Central Electricity Research Laboratories, United Kingdom

Jackson and Raask (Reference 39) and Jackson (Reference (40) reported on the' 'use of relatively large probes for use in oil and coal-fired boilers. In devieloping a probe they imposed the foliowing criteria: $\therefore \therefore$

(a) The probe must have a reasonably long life under arduous operating conditions.

(b) The temperature of the target should-be easily controlled over a wide range with simultaneous investigations at several temperatures highily desiräble.

(c) Contamination of the deposits by the target material should be r minimized.

(d) The temperature of the target must be constant and accurately known during each exposure.

$\because$ (e) The target area should be large enough to permit the collection of adequate quantities of deposit.

(f) The methods of analyzing the deposits must be sufficiently accurate $\therefore \quad$ to obtain results of adequate precision with small samples obtained $\because \quad$ during short exposure times.

$\because$

Subject to these constraints the development of a mass accumulation type probe was undertaken at the Central Electricity Research Laboratories (CERL) in the United. Kingdom.

A schematic diagram of a representative probe is shown in Fig. 3-10. The probe is constructed of austenitic steel (18 percent chromium, 10 percent 


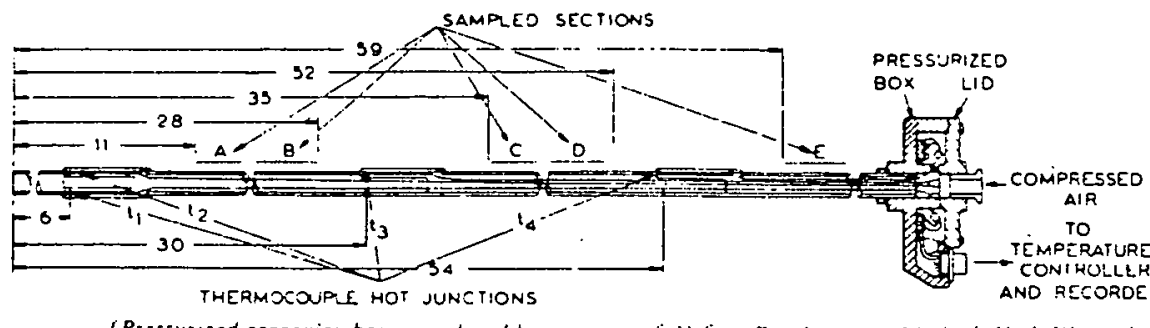

(Left) - High-temperature

deposition probe ; part section.

(Pressurized connexion box repraduced by courlesy of Airfiow Developments Limited, High Hycombe)

(Right) - Thermocouple mounting.

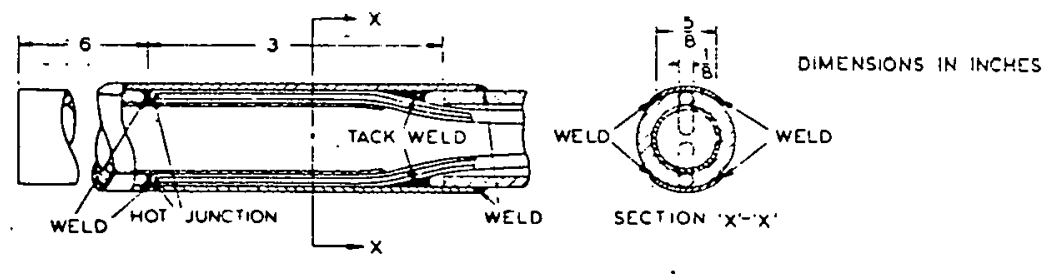

Figure 3-10. Central Electricity Research Laboratories Mass Accumulation Probe (Referenre $39-40$ )

nickel, and 3 percent molybdenum) tubing with 1 -in. 00 and $0.75-i n$. ID. Probes ranging in length from about. $6 \mathrm{ft}$ (as shown in Fig. 3-10) to $13 \mathrm{ft}$ have been... used with the $11-\mathrm{ft}$ length being the best for most boilers. Good thermal contact in the welds between the sheaths of the thermocouples and the tubewall, as indicated in Fig. 3-10, is essential to obtain accurate wall temperature measurements. The cooling medium was compressed air at 80 to 100 psig and was controlled automatically. Four Chromel-Alumel thermocouples are normally installed in any given probe. A safety device is included in the thermocouple circuit so that if the control fails, the cooling air control valve opens fully so that damage to the probe by overheating is prevented. The wall temperature of the probe was easily and accurately controlled in the range of 300 to $1500 \mathrm{~F}$ in the superheater region for fiue-gas temperatures between 1000 and $2100 \mathrm{~F}$. The results showed that the axial surface temperature gradient was essentially linear. Most test runs lasted between 30 and $120 \mathrm{~min}$, but at least one test was carried out for $350 \mathrm{hr}$. Refore parh expnsure, the prohe surfare was washed with deionized water, rubbed vigorously with a cotton cloth, and rinsed thoroughly with deionized water once again. The surface was allowed to dry before the probe was inserted into the flue qas. The probe temperature was allowed to rise near the desired value as quickly as possible, avoiding a temperature overshoot, and the cooling air supply controlled to maintain the local probe temperatures within $\pm 9 \mathrm{~F}$ of the desired values. In Reference 40 , 
deposits were analyzed using flame photometry (sodium), atomic absorption (vanadium and magnesium), and gravimetric analysis (sulfate). Three types of magnesium additives - - designated by. X, Y, and Z -- were also investigated. Tests were carried out with flue aas velocities of $3.5-10.2 \mathrm{ft} / \mathrm{sec}$ and excess air of 0.5 to 3.0 percent, with resulting deposits having a mass of at least $0.05 \mathrm{~g}$.

Central Electricity Research Laboratories, United Kingdom

Dalmon, Tidy, and Towell (Reference 41) reported on the description and use of a sampler such that the deposition surface forms a small section which is flush to the flue or duct wall. The goid-plated deposition surface is in the form of a 5.32-in. disc as shown in Fig. 3-11. As may be seen, the disc is carried by an inner cylinder along with a gas seal plate and heater. The cylinder can slide and rotate in another outer cylinder. An 0-ring provides a gas-tight seal as well as a thermal impedance between the cylinders in order to prevent aerodynamic interference and excessive temperature variations around the deposition disc. The disc is fastened to the cylinder using countersunk screws with an insulating gasket between the metal surfaces. Three thin

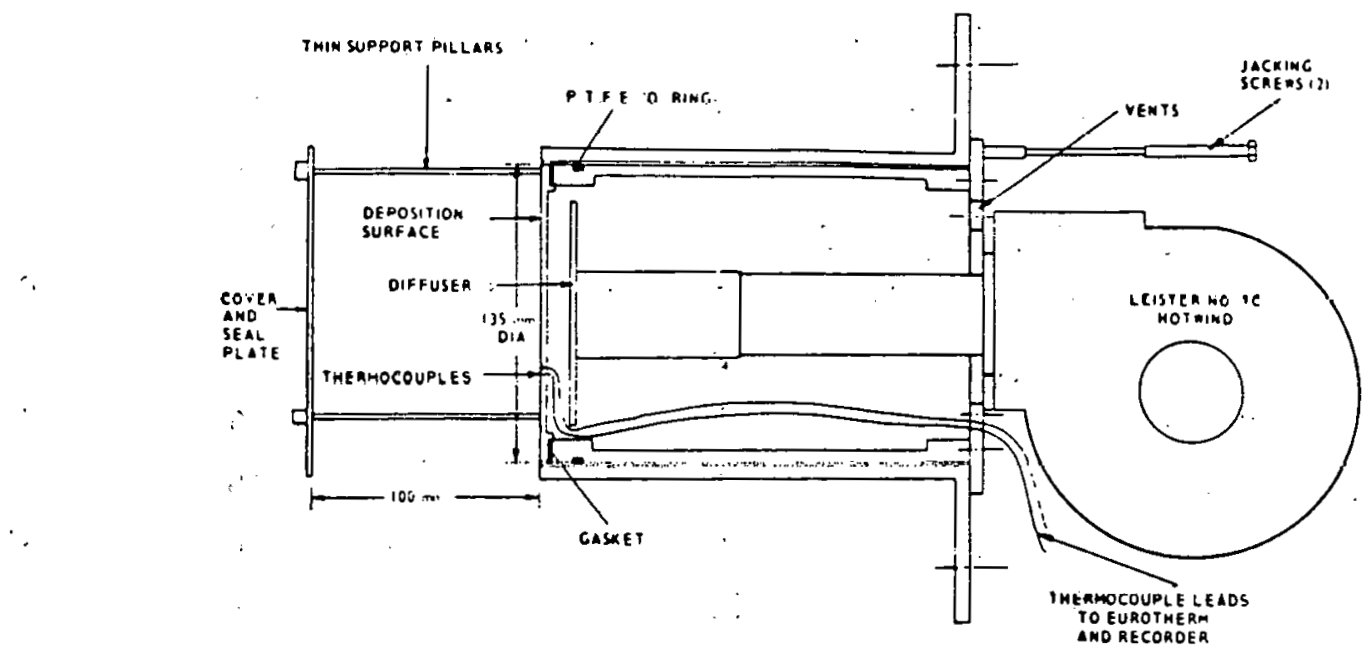

Figure 3-11. Central Electricity Research Laboratories Mass Accumulation Sampler Mk II (Reference 41) 
support pins 3.94 in. long are also screwed into the disc to support the gas seal plate as shown in Fig. 3-11. In the normal working position the seal plate is parallel to the gas flow and far enough from the deposition disc such that interference effects are essentially negligible. When the inner cylinder is fully retracted, the peripheral surface of the seal plate butts against the end of the outer cylinder thus sealing the disc in an atmosphere of stationary flue gas. Thus, the disc may be withdrawn from the duct with the boiler fully operational and with no disturbance to the collected deposit and acid layer. The disc is made of either a gold-plated brass or mild steel and is heated or cooled by a stream of air at a controlled temperature impinging on the back face of the disc. A temperature controller compares the signal from a Chromel-Alumel thermocouple embedded in the disc with a set temperature and modulates the heater power, thus maintaining the disc at a constant temperature. The entire device, which weighs about $36 \mathrm{lb}_{\mathrm{m}}$, may be used to collect either acid or solids, usually over a time interval of 6 to $24 \mathrm{hr}$. At the end of the exposure period the sampling disc is carefully withdrawn into its holder and the entire assembly is transported to a convenient location for sample removal.

The mass accumulation sampler has been used in units at three Central Electricity Generation Board (CEGB) power stations in the United Kingdom. In fact, the sampler is manufactured commercially and has been adopted as a standard instrument in one CEGB reaion. In these applications the apparatus has been quite reliable and routine maintenance includes the occasional replacement of 0-rings, gaskets, and thermocouples. The major problem is that of the need to replate the discs with a film of gold. Discs exposed at temperatures above the acid dew-point temperature suffer from erosion and require replating after about $24 \mathrm{hr}$ of operation. Reported tests have been carried out with gas temperatures of about $295 \mathrm{~F}$ and surface temperatures ranging from 158 to $320 \mathrm{~F}$.

\section{National Engineering Laboratory, Glasgow, Scotland}

The National Engineering Laboratory (NEL) in Glasgow, Scotland has recently developed a mass accumulation fouling probe (References 42-43). The 
test section is cooled by either air or water and both the pressure and flowrate are monitored. The sample pieces are thin cylindrical shells, 1.0 to $4.0 \mathrm{in.}$ long and $1.0 \mathrm{in}$. diameter, and at present are made of mild steel, stainless steel, and copper. The pieces consist of two half-shells for easy removal as shown in Fig. 3-12 with the entire probe assembly shown in Fig. 3-13. Instrumentation for the probe consists of thermocouples to measure the exhaust gas temperature, the cooling fluid inlet and outlet temperatures, and the sample section temperature; a differential pressure gage used with a pitot tube (shown in Fig. 3-13) for the determination of the exhaust gas velocity; and a flowmeter for the cooling fluid flowrate. A Standard Land Dew-Point Meter, chemical analysis, a BCURA dust sampling kit, and gas and liquid chromatography are used to analyze the exhaust gas, fouling deposits and the fuel. Based on earlier tests, a modified version of the NEL probe has been developed and a schematic drawing of the probe head is shown in Fig. 3-14. Additional details on the NEL probe may be found in Section 3.6 which deals with recent developments in the United Kingdom.

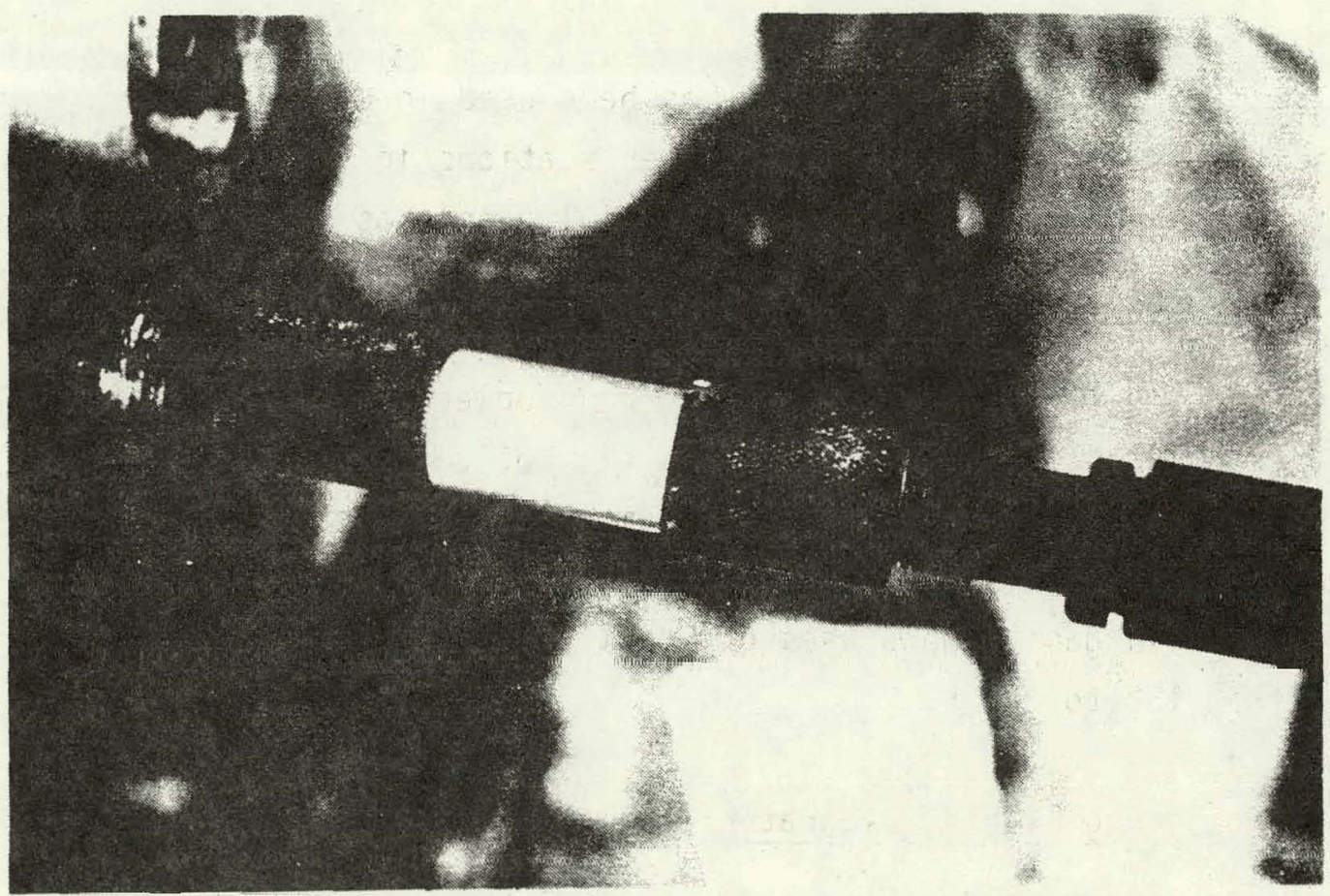

Figure 3-12. National Engineering Laboratory Mass Accumulation Probe Head (Reference 42) 


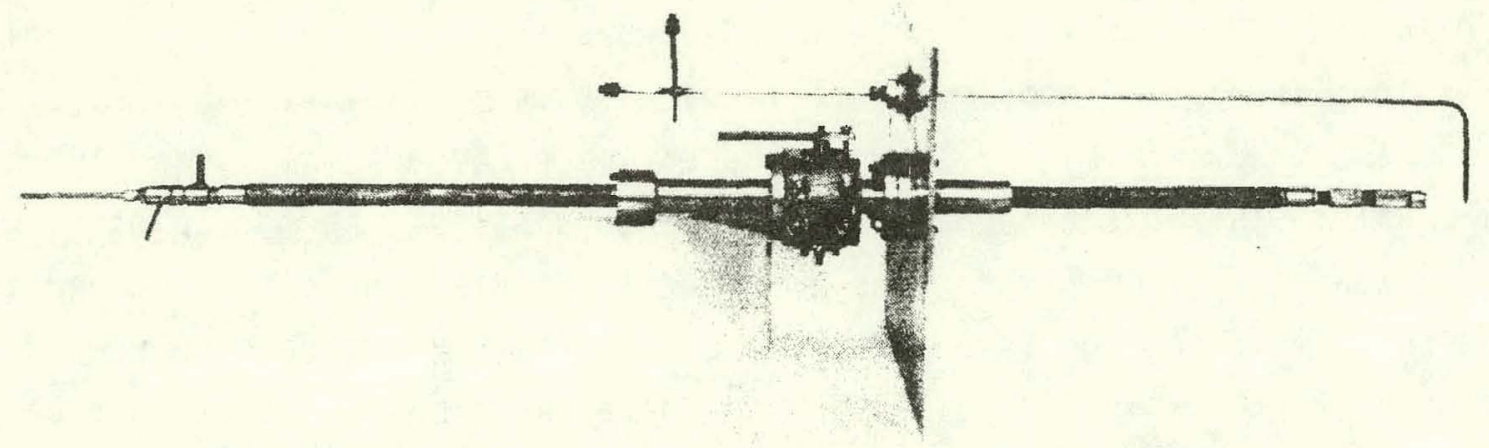

Figure 3-13. Natinnal Fngineering Laboratory Mass Accumulation Probe Assmmlly (Reference 42)

\section{Central Electricity Generating Board, United Kingdom}

Holland, et al. (Reference 44) reported on corrosion and deposition studies carried out at the Marchwood Power Station in the United Kingdom. This effort was actually carried out under the ioint sponsorship of CEGB, Esso Petroleum Company, Ltd., and John Thompson Water-Tube Boilers, Ltd. The objective of this study was to obtain information on high-temperature deposition and corrosion in oil-fired power plants. A portion of the study was carried out using mass accumulation probes of the type described by Jackson and Raask (References 39-40) which have already been considered. Of particular interest as far as the present study is roncerned is their use of single hairpin corrosion probes (which also collected depnsits) as shown in Fig. 3-15. Each probe was made entirely of a single material. In this study four different materials were used, namely AISI 347, 321, 316, and 420. The first. three types are austenitic stainless steels while the latter is a ferritic stainless steel. Although the overall length of these probes was about 124 in., the test section was $72 \mathrm{in.}$ in length. Over the test section length a total of 10 Pyrotenax thermocouples were installed to measure the wall temperature and were mounted in the tubewall as shown in Figure 3-15. Each 


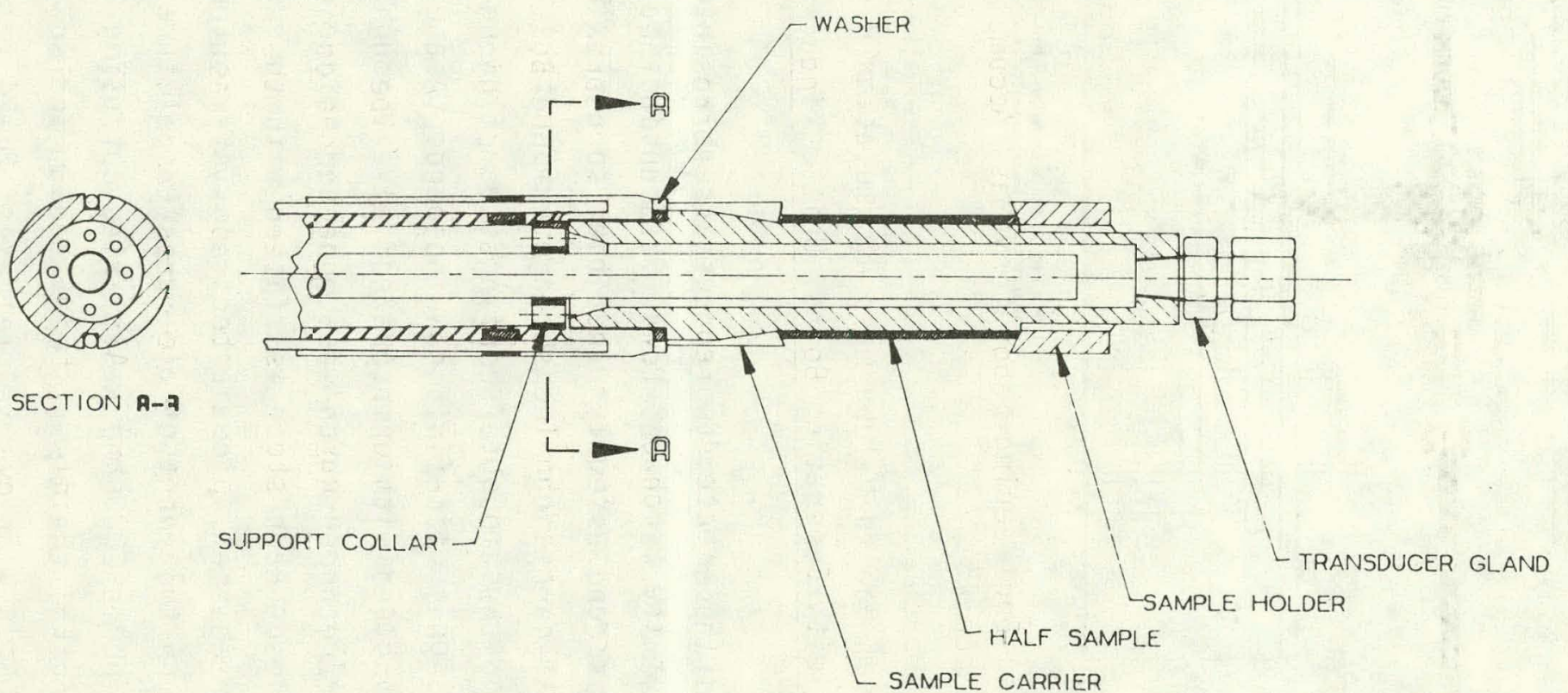

GAS FOULING PROBE MK 2

GENERAL ARRANGEMENT

Fiqure 3-14. Schematic Drawing of National Engineering Laboratory Mass Accumulation Model MK 2 Probe Head (Reference 42) 


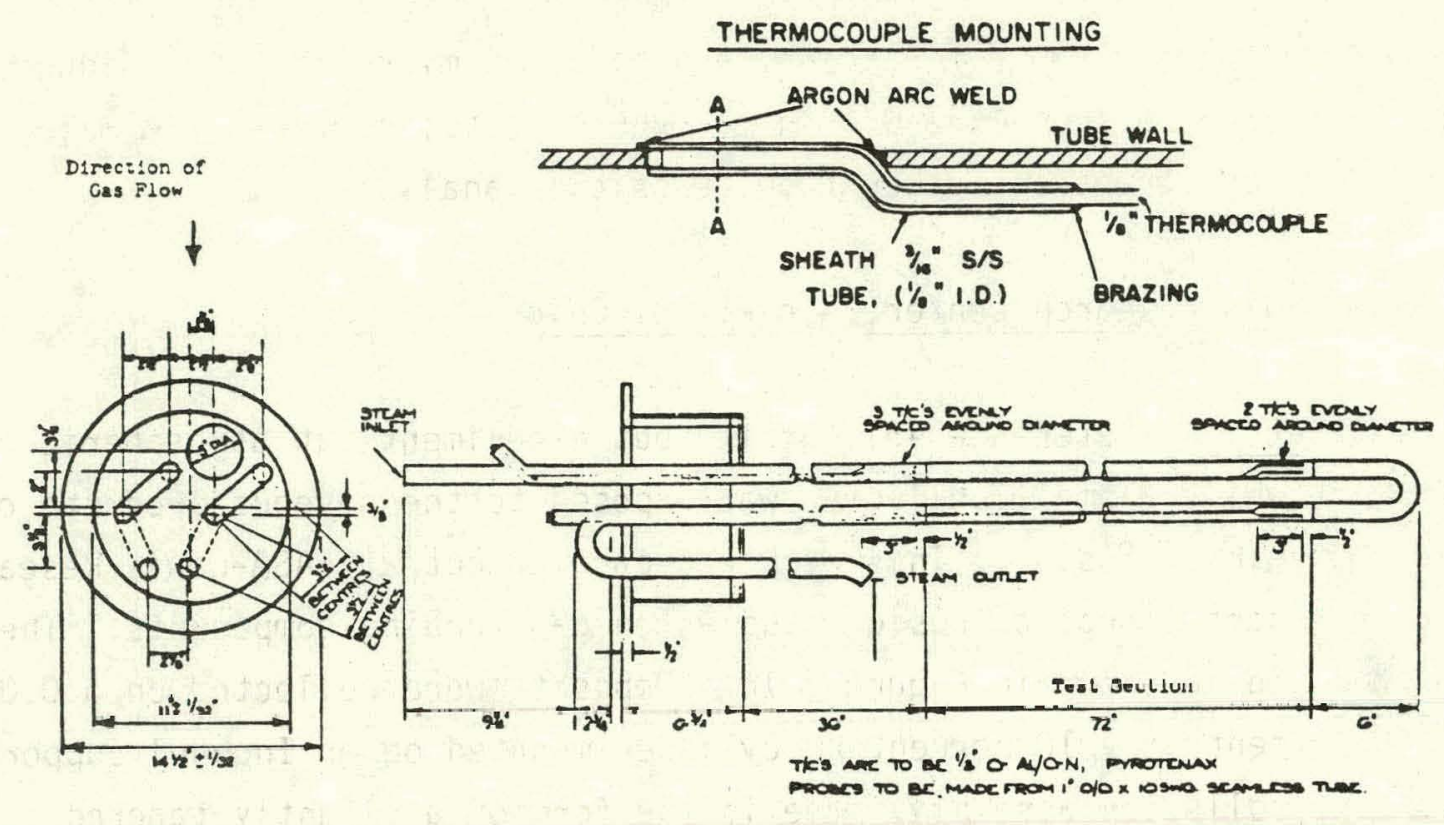

Figure 3-15. CEGB Steam-Cooled U-Tube Mass Accumulation Probe (Reference 44)

probe was $0.75 \mathrm{in}$. in diameter with two probes assembled into a common mounting head as shown. One assembly was fixed to a rigid automatically retractable rail system, while the second assembly was fitted to a flexible but non-automatic withdrawal carriage. The surface temperature of each probe was controlled by regulating the amount of cooling steam flowing through the inside of the tube. Each probe was fitted with an independent saturated steam supply (200 psi at 392 F) controlled with a motorized valve through an electronic proportional controller/recorder which was connected to one of the highesttemperature thermocouples. Each probe was fitted with an excess temperature audible and visual alarm system. An air control system automatically took over from the steam cooling in the event of an excess temperature owing to steam failure. The testing (up to $2000 \mathrm{hr}$ ) was carried out using a fuel oil specially blended to control the amounts of vanadium and sodium. Gas temperatures of 1940-2084 F with gas velocities of $22-24 \mathrm{ft} / \mathrm{sec}$ resulted in probe wall temperatures ranging from 212-1291 $\mathrm{F}$ with a nonlinear temperature gradient along the probe test length. The excess air was approximately 2.5 percent during these tests. Extensive deposit and corrosion analyses were 
carried out by employing paramagnetic techniques, chromatographic techniques, chemical analyses, $x$-ray diffraction, and electron microprobe techniques. The deposit mass ranged from 0.57-0.63 $\mathrm{g}$ for these tests; however, the major emphasis was on corrosion rather than deposition analysis.

\section{NASA-Lewis Research Center, Cleveland, Ohio}

Koh1, et al. (Reference 45) carried out experiments at atmospheric pressure in which a small collector was exposed to the gaseous products of a liquid fuel/air combustor. This work was carried out at NASA-Lewis Research Center as a part of hot corrosion studies on gas turbine components. The Mach 0.3 burner rig is shown in Fiqure 3-16. Deposits were collected on a 0.01-in.thick 90 percent Pt - 10 percent Rh cylinder mounted on an Inconel support as shown. The collector assembly, made in the form of a slightly tapered cylinder, consisted of a collector, a collector support including a stem, and a base. The collector height was $0.50 \mathrm{in}$. and the base diameter $0.50 \mathrm{in}$. with

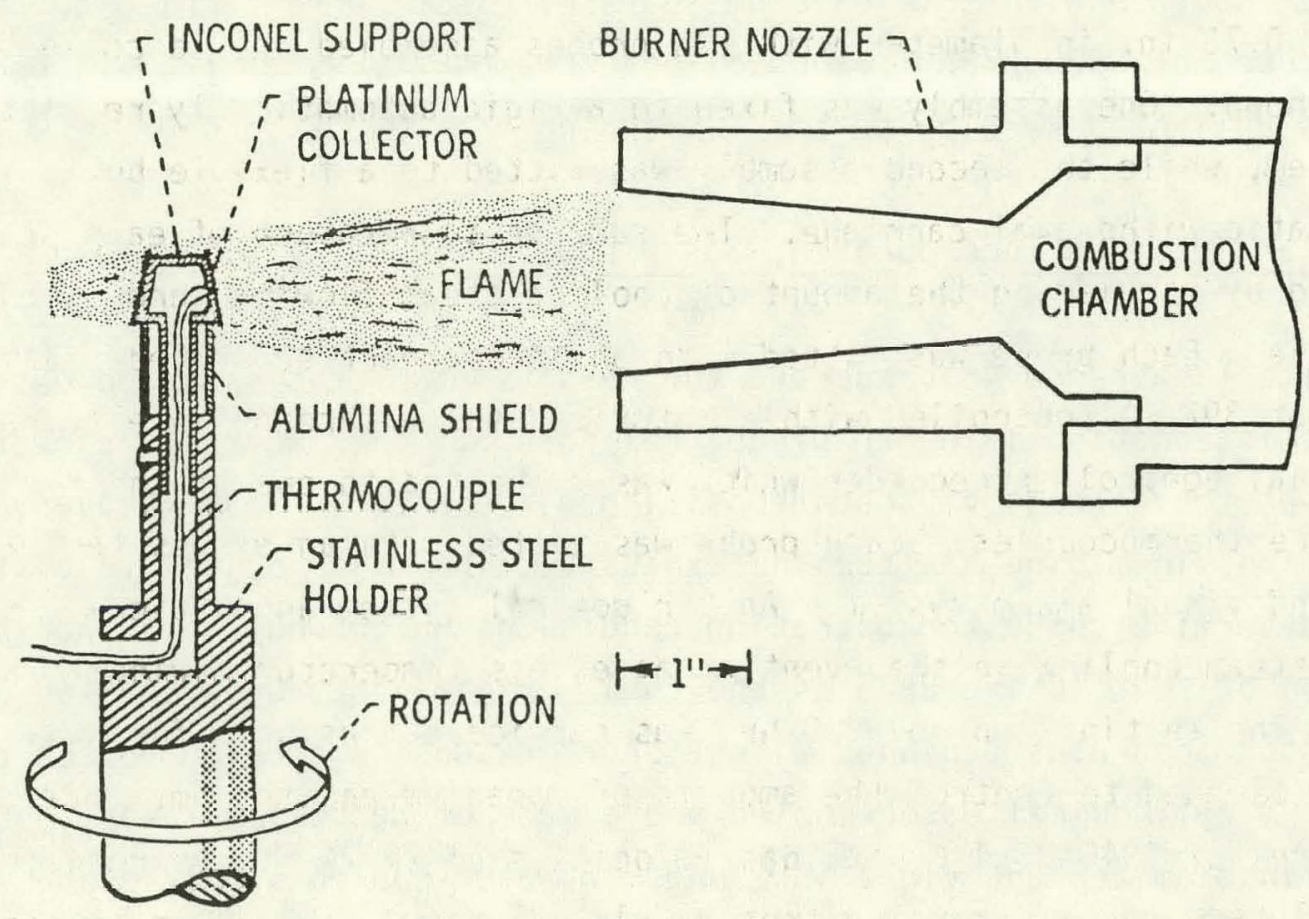

Figure 3-16. NASA-Lewis Rotating Cylinder Mass Accumulation Collector (Reference 45) 
a collector area of 0.786 in.2. The small collector size was chosen so that the surface temperature could be maintained at a constant temperature when the collector is placed in the burner flame. The support and its stem were made of Inconel (iN-600). The alumina shield acted as a thermal barrinr and thus prevented hot corrosion of the stem. A Chromel-Alumel thermocouple junction, peened in a hole in the wall of the collector support, was used to measure the collector surface temperature. The collector base, which was made of stainless steel, rotated the entire collector assembly at $600 \mathrm{rpm}$ to ensure a uniform collector temperature. The collector temperature was varied by adjusting the fuel flowrate into the burner. Most runs were six hr in length to ensure that sufficiently large deposits could be obtained for analysis. The tuel was Jet ruel A-1 with typical air/tuel ratios of $2 b$ (on a mass basis). The burner flame was doped with sea salt, sodium sulfate, or sodium chloride. Deposition rates of $\mathrm{Na}_{2} \mathrm{SO}_{4}$ and $\mathrm{CaSO}_{4}$ were studied as a function of collector temperature. Experimental dew-point temperatures of $\mathrm{Na}_{2} \mathrm{SO}_{4}$ and $\mathrm{CaSO}_{4}$ were compared with predicted values and showed good agreement. X-ray diffraction analysis was used to analyze the deposits which consisted primarily of sodium sulfate with some calcium sulfate. Tests were carried out with gas temperatures of 2520-2780 F, and collector temperatures of 1250-1880 F. The deposits collected were quite small, ranging from 0.002 to $0.018 \mathrm{~g}$.

\section{Solar Turbines Incorporated, San Diego, California}

White (Reference 46) reported the results of a study carried out at Solar Turbines International in San Diego, California. This work was directed toward a study of the effects of soot deposition as related to heat recovery applications in marine gas turbine exhausts. The major objective of the study was to determine combustor operating conditions which would prevent the formation of soot, using JP-5 as the fuel. Experiments were carried out using a combustor apparatus equipped with a short extension section on the combustor outlet. A cylindrical water-cooled probe made of Hastelloy- $X$ was approximately $1 / 2$ in. in diameter and eight in. long. A water-cooled sample probe was used for obtaining gas and particulate samples. Outlet combustion gas temperatures were designed for $1740 \mathrm{~F}$. A thermocouple was attached to the rear portion of the probe to measure the outside wall temperature of the probe which ranged 
from 172 to $230 \mathrm{~F}$ during the soot producing runs. The unburned hydrocarbons in the exhaust were determined using the flame detector method. Carbon monoxide and carbon dioxide were both determined by the nondispersive infrared method. The oxides of nitrogen were determined by the chemiluminescence method which is a chemical method based on the reaction of nitric oxide and ozone yielding nitrogen dioxide and oxygen. The smoke probe sample was conveyed to a Von Brand Smokemeter which indicated the suspended particulate matter in the gas stream. The soot which was deposited on the fouling probe was subjected to a variety of analyses including: pyrolysis gas chromatography, infrared absorption, scanning electron microscopy, and energy dispersive $X$-ray analysis. The test results showed that the rate of soot deposition was quite low, ranging from $4.4 \times 10^{-8}$ to $6.6 \times$ $10^{-8} \mathrm{ib} / \mathrm{sec}$, with the stoichiometric ratio (0.816 to 1.473$)$ a very important parameter. However, the most significant conclusion reached in the study was that it is difficult to produce soot or smoke when the fuel-air charge to the combustor is partially premixed.

\section{Central Electricity Generating Board, United Kingdom}

Horn and Street (References 47-49) in a series of three papers reported results obtained using both corrosion and mass accumulation probes. The latter air-cooled probe, of the type by Jackson and Raask (References 39-40) described earlier, was $11 \mathrm{ft}$ long and $1 \mathrm{in}$. in diameter. Testing was carried out in both oil and coal fired boilers with probe temperatures ranging from 1004 to $1652 \mathrm{~F}$ for tests up to $20 \mathrm{hr}$ in duration. Excess air ranged from 12 to 17 percent during the tests. Chemical analysis and X-ray diffraction were used to analyze the deposits.

\section{Grand Forks Energy Research Center, Grand Forks, North Dakota}

Tufte, et al., (Reference 50-53) developed a test procedure for use with a series of probes at the Grand Forks Energy Research Center (GFERC) in Grand Forks, North Dakota. The studies there have been concentrated in the area of low-rank Western United States coals, primarily because of the large lignite deposits in North Dakota. Research on fouling at the GFERC has primarily 
addressed the evaluation of gas-side fouling characteristics using a pulverized, coal-fired, pilot-plant combustor. The bottom-fired combustion chamber is $30 \mathrm{in.}$ in diameter by $8 \mathrm{ft}$ high and is refractory lined. The volumetric heat release rate is about $13,500 \mathrm{Btu} / \mathrm{hr}-\mathrm{ft}^{3}$. which is about the same as in a commercial boiler. The test coal was putverized to a fineness of approximately 80 percent through 200 mesh in a hammermill and charged to a volumetric feeder at a nominal flowrate of $751 \mathrm{bm} / \mathrm{hr}$. The combustion air, including nominally 30 percent excess air, is preheated to 700-900 F.

The total air used as primary, secondary, and tertiary are about 10, 30, and 60 percent respectively. Flue gases at about $2000 \mathrm{~F}$ leave the furnace and enter a 10-in.-square duct which is refractory lined. Three probe banks are located in this furnace exit duct and are designed to simulate superheater or
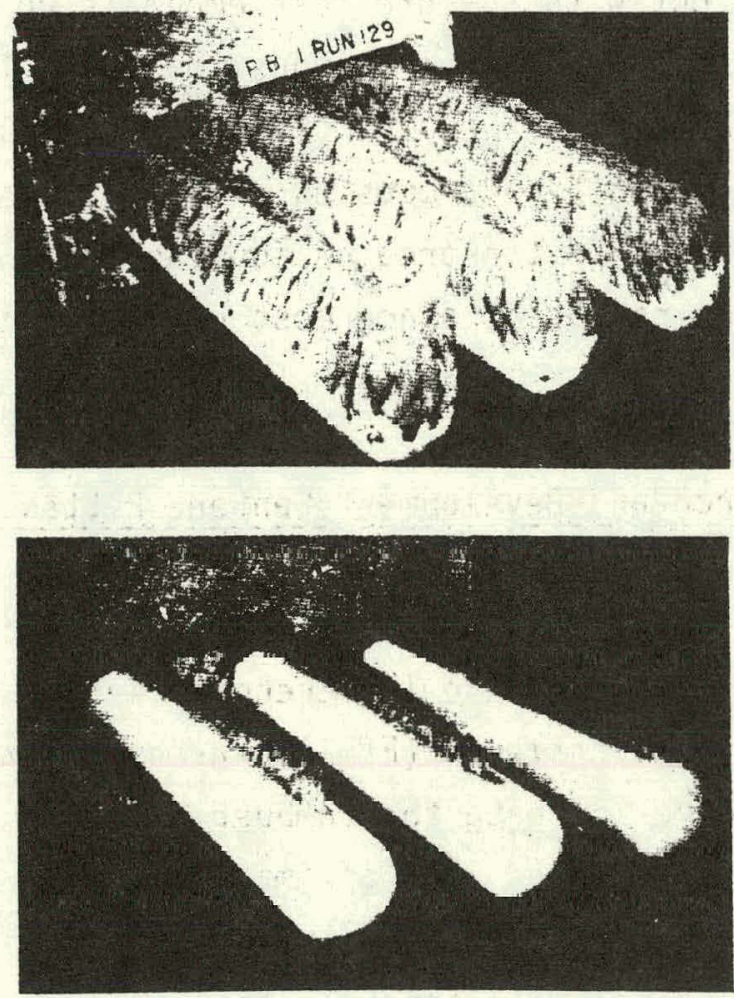

Figure 3-17. Fouled Probes in Grand Forks Energy Research Center Combustor (Reference 52) 
reheater surfaces in a commercial boiler. The first probe bank is oriented vertically while the second and third are horizontal. Typical probes in fouled condition are shown in Fig. 3-17. The probes in each of the three test banks are $1.66 \mathrm{in}$. in diameter, made of 304 stainless steel, and cooled using compressed air. The normal wall temperatures for probe banks 1, 2, and 3 are controlled at $1000 \mathrm{~F}, 1000 \mathrm{~F}$, and $800 \mathrm{~F}$, respectively. The maximum gas velocity between the tubes at the first probe bank is about $25 \mathrm{ft} / \mathrm{sec}$. The normal gas temperatures entering the first, second, and third banks are $2000 \mathrm{~F}, 1800 \mathrm{~F}$, and $1600 \mathrm{~F}$, respectively. The standard test procedure used to evaluate the fouling rates of test coals include a 1-1/2-hr preheat using natural gas, a 1-hr transition period burning both gas and coal, and a 5-1/4-hr test period burning coal only. This schedule permits completion of an entire test in one 8-hr shift. Steady-state conditions are maintained for the last three $\mathrm{hr}$ of each test. After cooling, the ash deposits are removed from the test probes, weighed, and analyzed. To date, approximately 100 coal samples in 380 different tests have been carried out with the greatest emphasis on North Dakota lignites, followed by Montana and Wyoming sub-bituminous coals and Texas lignite. Deposit samples of up to $800 \mathrm{~g}$ have indicated the predominant influence of sodium content on the gas-side deposition processes. The authors of these articles feel that continuing efforts in the area of fouling will "inevitably lead in the direction of more 'basic' research, since most of the empirical studies have already been performed."

\section{Westinghouse Research and Development Center, Pittshurgh, Pennsylvania}

In orier to obtain a better understanding of the problems associated with burning low-grade fuels, Westinghouse (References 54-57), under sponsorship by the Electric Power Research Institute (EPRI), has undertaken a program to obtain deposition and corrosion data for combustion turbine materials. The objectives of this effort were to: (a) optimize metal component temperature based on corrosion/ deposition considerations, (b) establish trade-offs between metal temperature, performance, maintenance, and reliability, and (c) develop a predictive model for deposition rates in combustion turbines burning low-grade, ash-bearing fuels that is capable of integrating laboratory and field experience. Tests were carried out in the Westinghouse R\&D Center pressurized 
turbine test passage $(3 \mathrm{~atm})$. Downstream of the test section the flow area is reduced such that the combustion gases attain a velocity of approximately 600 $\mathrm{ft} / \mathrm{sec}$. At this location cylindrical test specimens are exposed to the combustion gases. Multiple specimens (up to six per test) were either 2-in. long by 1 -in. diameter or 2.5-in. long by 0.5 -in diameter and were cooled by compressed air. The specimen holder could admit up to six cylindrical samples placed in two rows in a staggered arrangement having sufficient spacing to prevent contact of the thermal boundary layers and aerodynamic wakes of the cylinders. Several thermocouples were embedded in the wall of each specimen to measure the wall temperature. Although a temperature gradient occurred along the specimen length, the overall average metal temperature was maintained constant by adjusting the air mass flowrate. During the course of this work several fuels were tested including simulated and actual residual oils, washed and treated residual oil with and without additives, and SRC-II with heavy distillate. Materials tested included IN-738, IN-738 with LDC-2E coating, U-520, ECY-768, IN-713C, IN 617, HA-188, X-45, IN 617/LDC-2C, X-45/ATD-2, and Udimet 500. Gas temperatures varied between 1650 and $2300 \mathrm{~F}$ while wall temperatures ranged from 931 to $1710 \mathrm{~F}$. A variety of diagnostic techniques were utilized including: an isokinetic sampling probe, scanning electron microscopy, enerqy dispersive $X$-ray analysis, X-ray diffraction, emission spectroscopy, atomic absorption techniques, and electron beam microanalysis. Sample periods varied up to $300 \mathrm{hr}$.

Department of Physical Sciences, The Polytechnic, Wolverhampton, United Kingdom

Bishop and Cliffe (Reference 58) studied the deposition of sodium chloride from the products of combustion leaving a propane-tired combustor. An aqueous solution containing a known concentration of $\mathrm{NaCl}$ provided the sodium chloride in the combustion qases. The combustion chamber was $15.75 \mathrm{in}$. in (internal) diameter and operated at a positive pressure of $8 \mathrm{~mm}$ water. The core of hot turbulent aases had essentially uniform velocity and temperature profiles just upstream of the test section which consisted of a 2.01-in.-diameter cylinder about $1.0 \mathrm{in}$. in length with spigotted support tubes as shown in Fig. 3-18. The target tube was machined from 12 percent chromium steel tubina. The 


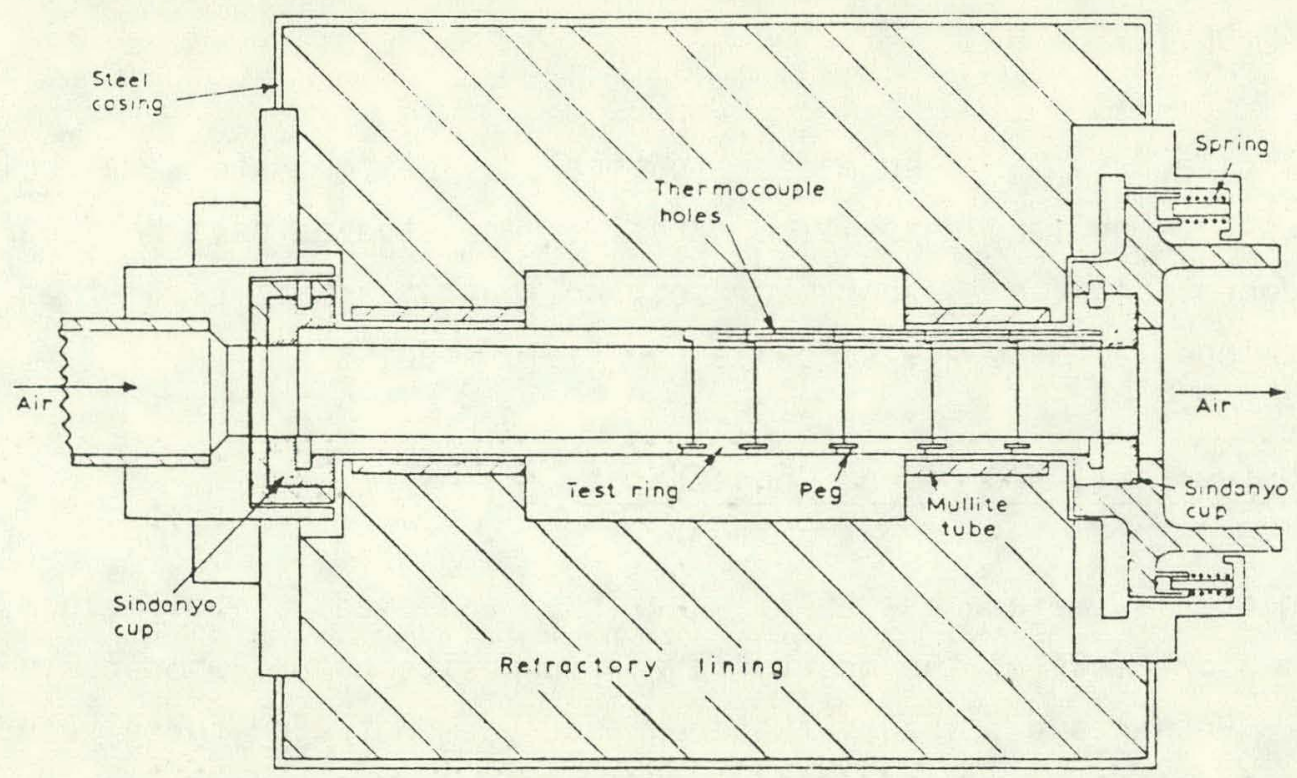

Figure 3-18. Test Section of Mass Accumulation Probe Located at The Polytechnic, Wolverhampton (Reference 58)

assembly was seated in Sindanyo cups of low thermal conductivity, as indicated, to reduct the longitudinal heat conduction. Pairs of clearance holes for 1.05-mm-diameter thermocouples were drilled along the tubewall parallel to the axis of the target. tuhe as shown. Coil springs allowed for expansion of the assembly and prevented distortion of the spigot joints. The entire tube assembly could be rotated through 30 degree increments and firmly pegged in each position. This rotation enabled the temperature distribution around the periphery of the central test ring to be determined from the readings of a single pair of thermocouples. The upstream and downstream deposits were microscopically examined and weighed separately. The flue gas temperature was maintained at about $2012 \mathrm{~F}$, with the surface temperature varying from 1022 to $1472 \mathrm{~F}$ for gas velocities of 34.4 to $98.4 \mathrm{ft} / \mathrm{sec}$. Tests were conducted for relatively short. times of 10 to $15 \mathrm{~min}$. 


\subsection{OPTICAL DEVICES}

Very limited use has been made of optical devices to date as a tool for studying gas-side fouling deposition rates. These studies have been carried out using doped fuels in a laboratory setting, but it is not clear that the methods developed to date are suitable for field studies.

\section{Yale University, New Haven, Connecticut}

Rosner et a1. (References 59-61) developed and used optical methods for real-time measurements of the growth rate of deposits under laboratory conditions. Rosner and Seshadri (Reference 60) demonstrated these techniques by adding $\mathrm{BCl}_{3}(\mathrm{~g})$ to a premixed $\mathrm{C}_{3} \mathrm{H}_{8}$-air flat flame and the $\mathrm{B}_{2} \mathrm{O}_{3}$ deposition rate on an electrically heated platinum ribbon was measured using interference and ellipsometric methods over a range of fuel/air ratios and seed levels. This study focused on the experimental determination of vapor and small-particle, i.e., non-inertial, deposition. In the interference method, use is made of the fact that when a well-collimated beam of light from a laser is incident upon the substrate on which condensate growth is occurring, a fraction of the beam is reflected from its front surface, and the remaining fraction is reflected from the substrate-deposit interface after being transmitted through the layer. These reflected beams constructively or destructively interfere, depending upon the instantaneous deposit thickness. Therefore, by recording the reflected intensity versus time, the growth rate of the deposit can be obtained accurately in real time. In the ellipsometric (polarization) method, the change in the state of polarization (intensity ratios and phase lags) of the reflected light as the thickness grows is exploited. The apparatus is shown in Fiq. 3-19 and consists of: (a) an optical system for measuring dew-point and growth rates, (b) an electrical system for heating the platinum ribbon and measuring its temperature, (c) the flat flame burner assembly, and (d) the gas feed system (not shown). A He/Ne laser was used as the source of well-collimated, monochromatic $(0.6328 \mu \mathrm{m})$ light. A 0.24 in. wide, 0.005 in. thick Pt ribbon spanning two copper rods was positioned $1.50 \mathrm{in}$. above the burner where the flow was laminar and undiluted. The ribbon was slightly less than $3.74 \mathrm{in}$. long as indicated. The ribbon was 


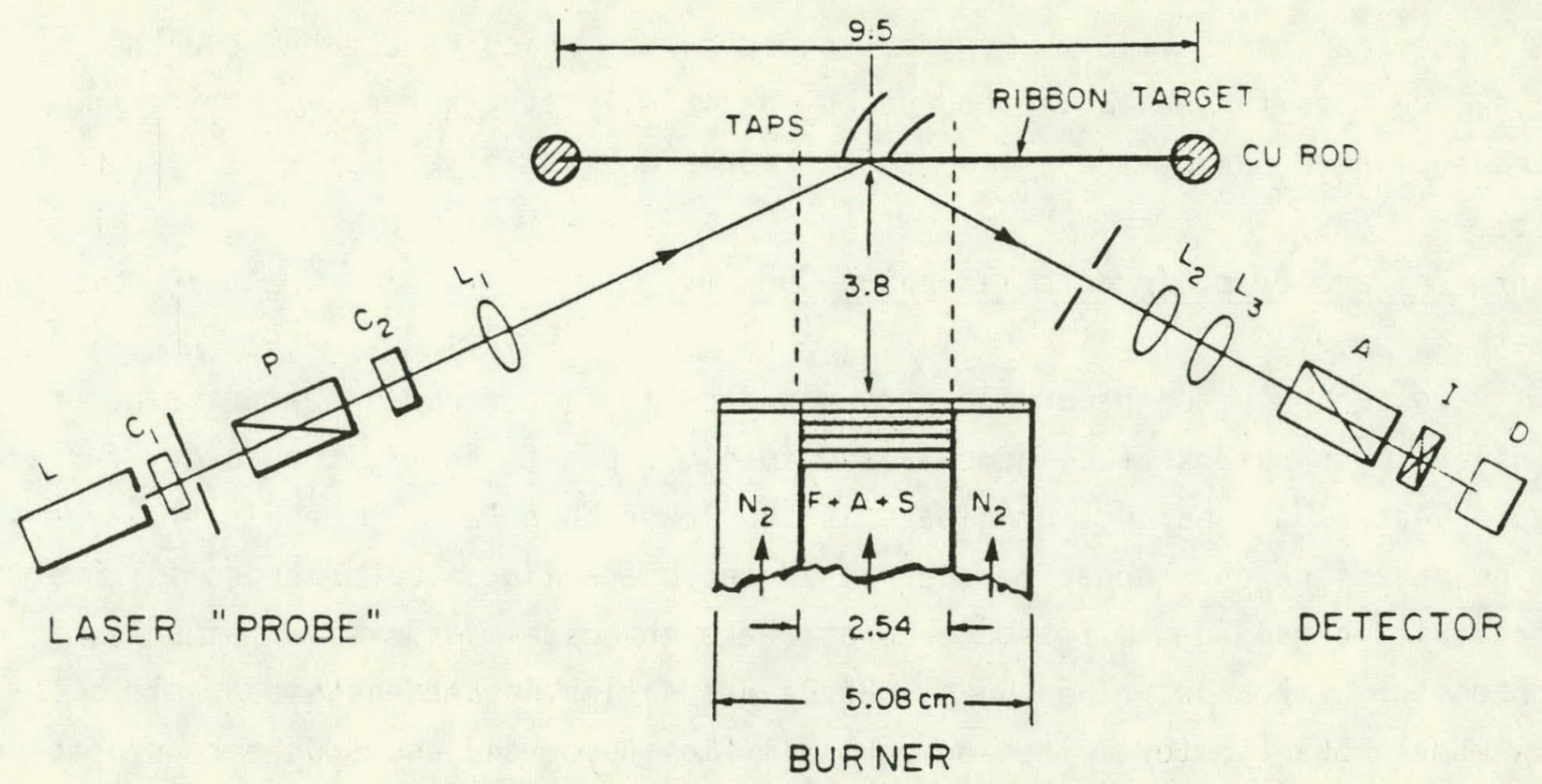

Figure 3-19. Optical Mass Accumulation Setup at Yale University;

$L=$ Laser, $C_{1}=1 / 4$ Wave Plate, $P=$ Polarizer, $C_{2}=$ Compensator, $A=$ Analyzer, $I=$ Filter, $D^{2}=$ Detector, and $L_{1}, L_{2}, L_{3}=$ Focusing Lenses (Reference 61)

heated electrically to temperatures in the 1700-1880 $\mathrm{F}$ range using a 50-amp d.c. power supply and the temperatures of its 0.158-in.-long central section were obtained from its resistance. The premixed gaseous stream of $\mathrm{C}_{3} \mathrm{H}_{8}$ fuel and seed vapor $\mathrm{BCl}_{3}$ were determined using rotameters. The duration of the tests ranged up to three min, but some were as brief as $15 \mathrm{sec}$. The composition of a typical film was analyzed using an X-ray photoelectron spectrometer. For further details regarding optical methods, the reader is referred to those references which have been cited.

\subsection{DEPOSITION PROBES}

The deposition probe is the next type of device to be considered. No attempt is made to quantitatively determine the mass of the collected deposit with a deposition probe. However, the deposit is usually analyzed to determine 
its chemical composition. Many corrosion probes which have been developed, i.e., devices for which the corrosion analysis is of greater importance than the fouling deposit, are of the deposition probe variety.

\section{University of Toronto, Toronto, Canada}

In the pulp and paper industry gas-side fouling occurs in kraft recovery boilers which use kraft liquor as the fuel. Deposits in kraft recovery furnace superheaters and boilers originate in the lower furnace as a result of large concentrations of inorganic material in the black liquor. The deposits consist primarily of sodium sulfate, carbonate, and chloride with smaller amounts of potassium compounds. The two principle deposition mechanisms are due to inertial impaction of molten or partially molten particles and the condensation ur vapurs of lhe mure vulalile inurydnic maleridl imludiny sudium sulfale, sodium carbonate, sodium hydroxide, and sodium chloride. Reeve, Tran, and Barham (References 62-64) have reported on the use of a probe to study superheater deposits and corrosion in kraft recovery boilers. These investigations were carried out under the direction of the Department of Chemical Engineering and Applied Science at the University of Toronto. A schematic view of the probe used in the studies is shown in Fig. 3-20, including sketches of typical deposit tendencies which show that the heaviest deposits formed on the cold end of the probe. The probe material and probe diameter were not specified in the papers. However, the probes extended about $b .2 b$ tt into the flow and were located near the superheater at both a lower and a higher elevation in the furnace. The wall temperature varied in a nonlinear manner along the length of the probe from about 430-1070 F as measured by eight thermocouples located at four places along the probe. Flue gas temperatures near the probe varied from 950 to $1460 \mathrm{~F}$. The probe temperature was controlled by cooling air which was then exhausted into the furnace as shown in Fig. 3-20. Sampling periods ranged up to $70 \mathrm{hr}$ at the upper location and $900 \mathrm{hr}$ at the lower location. The deposits were investigated using chemical analysis, scanning electron microscopy, cone slumping techniques, atomic absorption spectroscopy, neutron activation, and differential thermal analysis. 


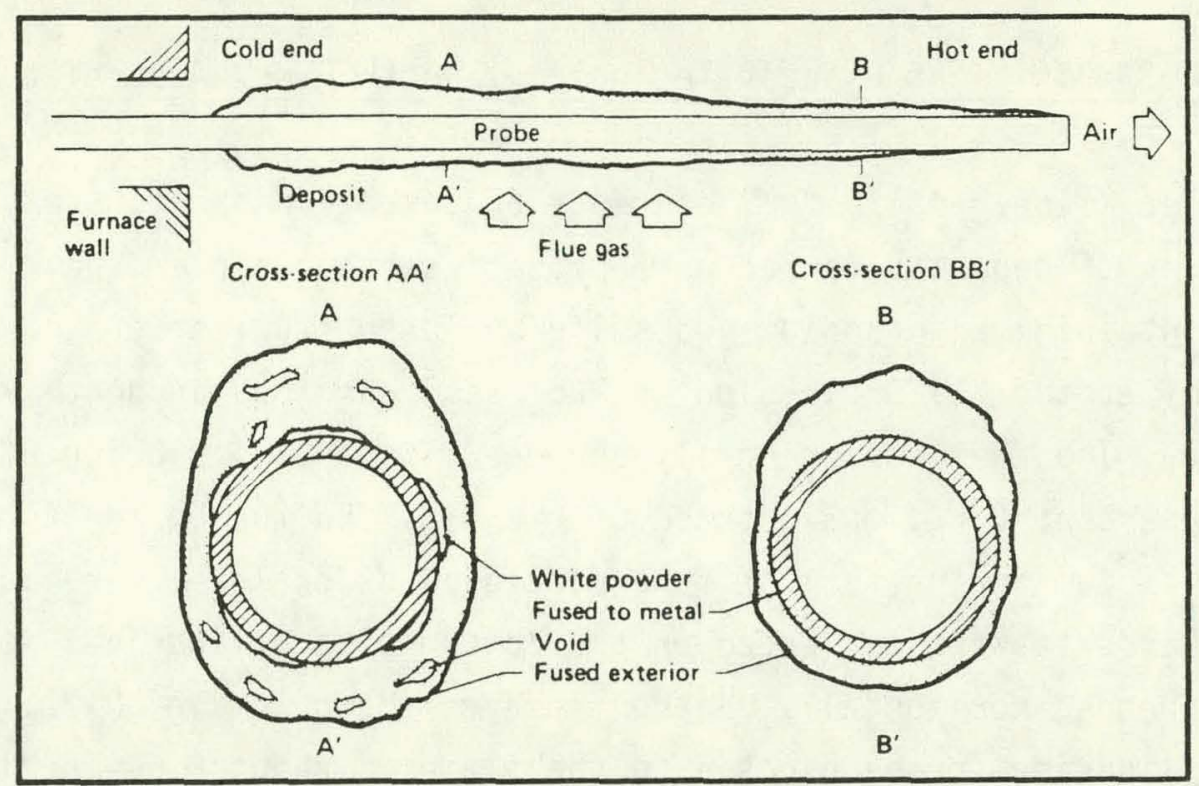

Figure 3-20. Deposit Formation on an Air-Cooled Probe in a Kraft Recovery Boiler (Reference 63)

Department of the Interior, Washington, D.C.

Barkley, Burdick, and Berk (Reference 65) reported on the use of Targe probes to study deposits obtained in three coal-fired boilers located at the Naval Gun Factory in Washington, D.C. The cylindrical probe was 6-ft, 4-in. long and was made of 1.5-in.-diameter steel pipe. The probe was designed so that either saturated steam or water at various temperatures could be used to maintain the probe at a desired surface temperature. A wide range of operating conditions was investigated. Flue gas temperatures varied from 500 to $1250 \mathrm{~F}$ with surface temperatures ranging from 150 to $877 \mathrm{~F}$, the higher temperature occurring when the probe was not cooled. An ASME Power Test Code method was used to analyze $\mathrm{SO}_{2}$ and $\mathrm{SO}_{3}$ in the combustion products, and a number of fly ash samples were also collected at the boiler outlet as part of the effort to characterize the combustion gases. Extensive chemical analyses were made on the deposits in order to obtaina better understanding of the various deposition and corrosion mechanisms which were taking place in the coal-fired boilers. In addition to the deposits collected on the cooled probe, much smaller deposits were also collected on an uncooled probe as mentioned above. 
Durie, Milne, and Smith (Reference 66) used a probe to study the composition of deposits formed on a probe inserted in premixed hydrocarbon-air flames containing both sodium and sulfur. These studies were carried out in a laboratory at the CSIRO Division of Process Technology in North Ryde, Australia. The fuel was primarily propane, its analysis being 86 percent $\mathrm{C}_{3} \mathrm{H}_{8}$, 14 percent $\mathrm{C}_{3} \mathrm{H}_{6}$, and a trace of $n-\mathrm{C}_{4} \mathrm{H}_{10}$. Sulfur in the form of $\mathrm{SO}_{2}$, and sodium in the form of fine particles of oxalate, were added to the flame. Deposits were collected on the bottom of a cylindrical stainless steel probe suspended horizontally in the flame as shown in Fig. 3-21. The portion of the cylindrical probe exposed to the flame is about 0.60-in. in diameter and $4.0 \mathrm{in}$. in length. The surface temperature of the probe was maintained at $840 \mathrm{~F}$ by means of air, which entered and exhausted from each side of the probe, and was controlled by adjusting the internal cooling air using a solenoid valve linked to a temperature controller. A Chromel-Alumel thermocouple embedded in the wall of the probe midway along the length was used to determine the surface temperature. Gas velocities during these tests varied from 3.9 to $4.6 \mathrm{ft} / \mathrm{sec}$.

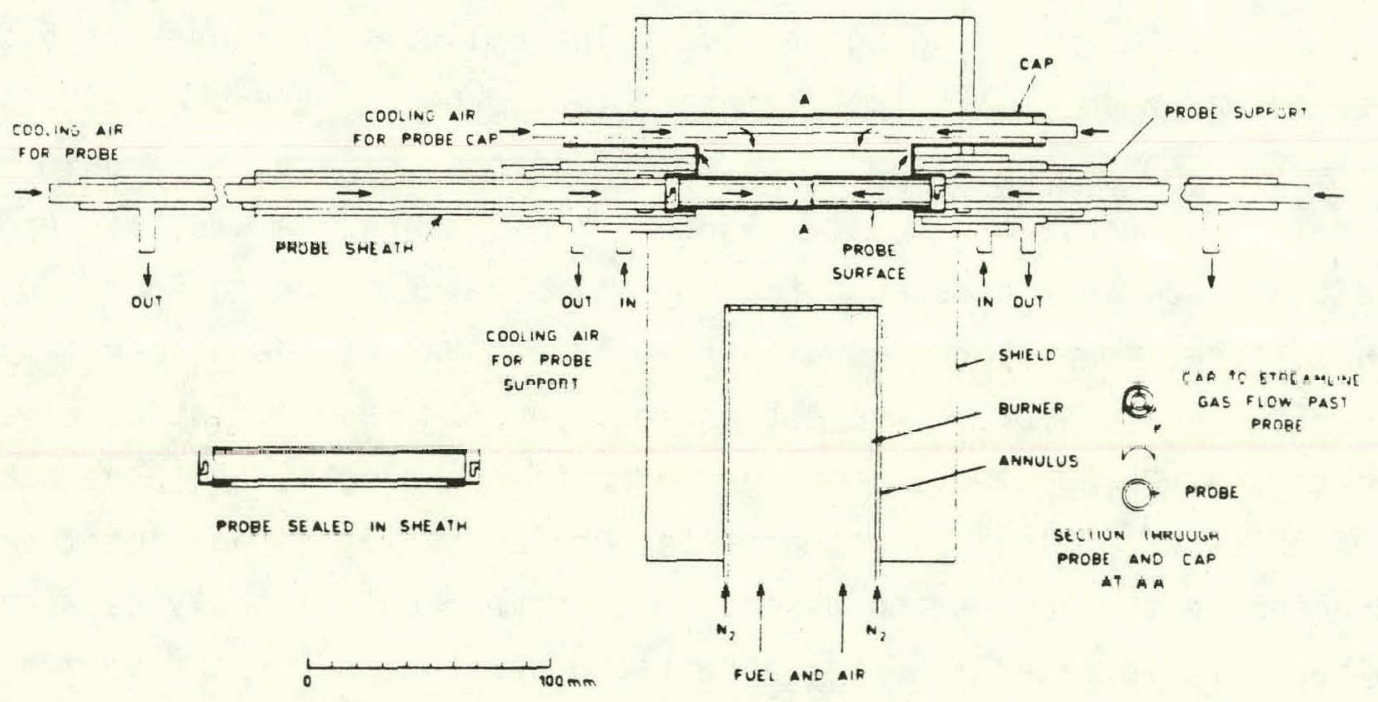

Figure 3-21. Burner and Probe Assembly at the CSIRO Division of Process Technology, North Ryde, Australia (Reference. 66) 
Run times were quite short, typically lasting from 17 to $25 \mathrm{~min}$ with resulting deposits on th order of $0.05 \mathrm{~g}$. The deposits contained primarily $\mathrm{Na}_{2} \mathrm{CO}_{3}$, $\mathrm{Na}_{2} \mathrm{SO}_{3}$, and $\mathrm{Na}_{2} \mathrm{SO}_{4}$, and were analyzed using infrared spectroscopy and using wet chemistry methods. Other parameters included excess air $(-40$ to +10 percent) and probe height above the burner. Special precautions were taken to protect the deposits from contact with the atmosphere because it was found that some of the finely divided solids deposited from the flames could be unusually reactive. Therefore, at the end of each run the fuel and air supply to the burner were stopped and the nitrogen flow through the burner annulus was maintained while the probe was withdrawn rapidly into a cylindrical sheath as shown in Fig. 3-21. Although Durie et al. used this probe as a deposition device, it could also be used as a mass accumulation probe.

\section{University of Tennessee Space Institute, Tullahoma, Tennessee.}

In an open-cycle magnetohydrodynamic (MHD) plant, electrical power is generated by the movement of ionized, high-velocity gases passing through a magnetic field which in turn induces an electric field. Making the fluid in a MHD generator an electrical conductor requires $5000 \mathrm{~F}$ gas temperatures and the addition of an easily ionizable material called seed. One of the most commonly used seed materials is potassium in the form of potassium carbonate with about one percent by weight required in the combustion gases which are generally produced by burning coal. Thus, in downstream heat recovery systems, gas-side fouling may occur because of ash deposition as well as seed-related deposition.

White and Attig (Reference 67) described the results from two series of tests (Series TP 37 and TP 41) carried out at the University of Tennessee Space Institute (UTSI) in Tullahoma, Tennessee. Both of these series of tests were performed in the UTSI coal-fired 7.5 MW facility. A mixture of pulverized coal and $\mathrm{K}_{2} \mathrm{CO}_{3}$ seed was injected into the primary combustor, resulting in particulates of $0.3-2.5 \mu \mathrm{m}$ in diameter. Two air-cooled deposition probes were used during the Series TP 41 tests in order to simulate boiler and superheater surfaces. The superheater probe had 12 different alloy samples as indicated in Fig. 3-22. The probe length and diameter (probably about 0.5-in. 
diameter) were not given in the paper. For gas temperatures of about $1385 \mathrm{~F}$, the superheater probe metal temperatures ranged from 1000-1187 $\mathrm{F}$ in an oxidizing environment (stoichiometric ratio of 1.15). Exposure time was 70 min for the superheater probe. A similar boiler probe, consisting only of carbon steel segments, was subjected to metal temperatures of 525-834 $\mathrm{F}$ in a reducing environment (stoichiometric ratio of 0.85 ) with the flue gases at about $1475 \mathrm{~F}$. Total exposure times for the boiler probe were about $240 \mathrm{~min}$. Analysis of the boiler probe deposits and associated corrosion was carried out using EDAX and chemical analysis.

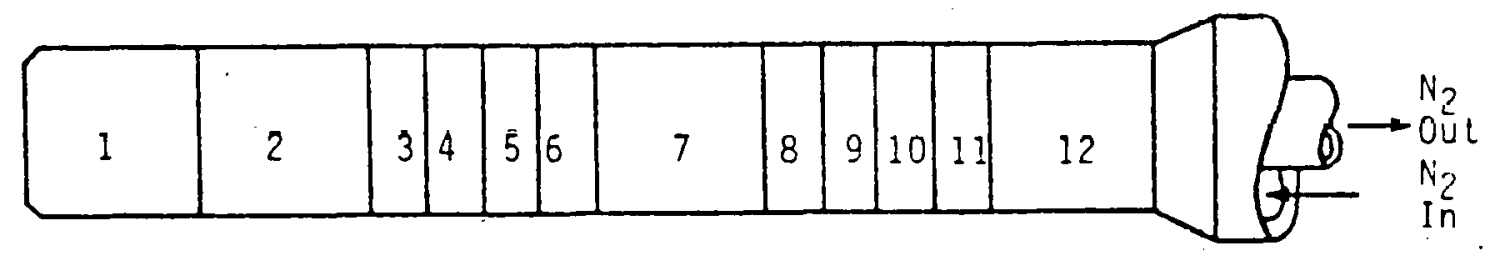

\begin{tabular}{|c|c|c|c|}
\hline Part No. & Description & Material & Mid-Point Temperature \\
\hline 1 & End Cap & $316 \mathrm{~L}$ S.S. & - \\
\hline 2 & Spacer 1 & 304 S.S. & $912 K(1182 F)$ \\
\hline 3 & Sample 1 & 1030 carbon steel & $908 \mathrm{~K}(1175 \mathrm{~F})$ \\
\hline 4 & Sample 2 & $1 / 2$ Croloy & $898 \mathrm{~K}(1157 \mathrm{~F})$ \\
\hline 5 & Sample 3 & $2-1 / 4$ croloy & $888 \mathrm{~K}(1139 \mathrm{~F})$ \\
\hline 6 & Sample 4 & 304 S.S. & $878 \mathrm{~K}(1121 \mathrm{~F})$ \\
\hline 7 & Spacer 2 & S.S. & $866 \mathrm{~K}(1100 \mathrm{~F})$ \\
\hline 8 & Sample 5 & 9 Croloy & $849 \mathrm{~K}(1069 \mathrm{~F})$ \\
\hline 9 & Sample 6 & 310 S.S. & $844 K(1060 \mathrm{~F})$ \\
\hline 10 & Sample 7 & $316 \mathrm{~S} . \mathrm{S}$. & $840 \mathrm{~K}(1053 \mathrm{~F})$ \\
\hline 11 & Sample 8 & 446 S.S. & $835 \mathrm{~K}(1044 \mathrm{~F})$ \\
\hline 12 & Spacer 3 & 304 S.S. & $815 \mathrm{~K}(1007 \mathrm{~F})$ \\
\hline
\end{tabular}

Figure 3-22. Superheater Deposition Probe at the University of Tennessee Space Institute MHD Facility (Reference 67) 


\section{Battelle Columbus Laboratories, Columbus Ohio}

Since about 1970, Battelle Columbus Laboratories (References 68-76) has been engaged in a study of ash deposits and corrosion using various waste materials. Fuels have included solid waste, refuse, combined refuse and coal, refuse and sewage sludge, and simulated fuels. These studies have been carried out in a laboratory setting as well as in municipal incinerators and municipal electric plants. Although the Battelle studies have been focused on corrosion, their investigations have clearly shown the intimate relationship between gas-side deposits and corrosion when burning wastes. One of the early ob,iectives of this effort was focused on the design of a suitable probe for deposition and corrosion studies. Two objectives had to be satisfied: (a) to provide a means for simultaneously exposing a number of specimens (or segments) for extended periods of time in an operating incinerator while maintaining the segments at temperatures in the range of 400 to $1100 \mathrm{~F}$, and (b) to provide a control system to maintain the temperature of the segments above the dew-point of the incinerator gases when the unit was not being fired.

The probe was designed to include 34 cylindrical segments as shown in Fig. 3-23 nested together end-to-end and then inserted into the incinerator through a side wall. The section of the probe extending through the wall was water cooled while the segments exposed within the furnace were cooled by air flowing inside the tubular seaments. A computer analysis was used to ascertain the geometry of the internal support tuhe required to give a linear temperature gradient from about 350 to $1300 \mathrm{~F}$ along the probe. Each segment was about. 1.25-in. $O D$ and $1.5 \mathrm{in.}$ long. The portion of the probe length inside the incinerator was approximately $70 \mathrm{in}$. long with the air-cooled test section $51 \mathrm{in}$. in length. The segments were nested together with lap joints as shown in Fig. 3-23 and were constrained axially at the cooling air outlet by a retainer which was fixed to the internal support tube with webs as shown. The axial restraining force in the internal support tube was obtained by compressing the spring on the air inlet end of the probe which also compensated for differential thermal expansion between the 34 different segments and the internal support tube. Temperatures of the seaments were measured at four stations with Type $K$ (Chromel-Alumel) thermocouples, either welded into the 


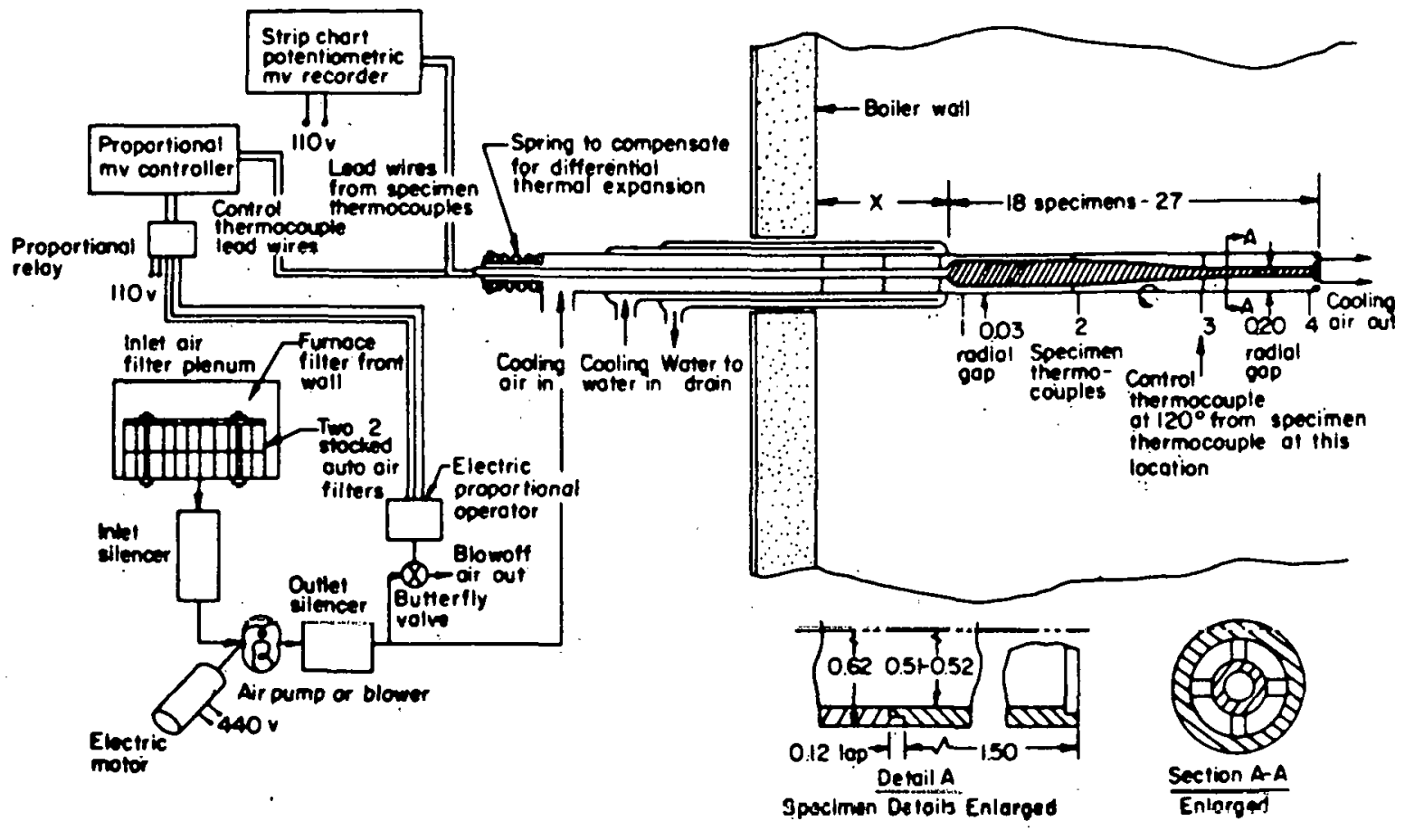

Figure 3-23. Schematic Drawing of Battelle Columbus Laboratories Deposition Probe (Reference 75)

wall of the segments or inserted into recesses drilled lengthwise into one end of the segment as shown in Fig. 3-23. The thermocouple lead wires were brought out of the probe through the center of the internal support tube as indicated. Temperatures of the intermediate segments were obtained by linear interpolation of the measured temperatures. The temperatures of the segments were controlled by regulating the amount of cooling air admitted to the probe. The output from a control thermocouple attached to one of the segments was monitored by a proportional temperature controller. The secondary control system shown in Fig. 3-23 was installed to maintain the segment temperatures above the dew-point when the incinerator was not being fired. This objective was accomplished by venting the cooling water from the water jacket upstream of the segments with the solenoid valves and by heating the cooling air flow with a resistance heater.

Previous experience with fireside corrosion in municipal incinerators had shown a decreasing corrosion rate with increasing time; therefore, the magnitude of attack in short exposure periods was expected to be sufficient to 
reveal differences as a function of fuel composition. Hence, a short (less than $10 \mathrm{hr}$ ) exposure time was selected for the investigation of corrosion rate as a function of the system parameters. In the course of the multi-year effort, a number of different materials and coatings were tested including among others: Carbon Steel A106-Grade B; Carbon Steel A213-T11; Stainless Stee Is 304, 321, 310, 405, 416, 316, and 431; Incoloy 825; and Inconel 600 and 601 as well as several coatings. As discussed previously, the major emphasis in this effort was on corrosion rather than on fouling. However, systematic studies included flue gas analysis, fuel analysis, corrosion analysis, and deposit analysis: A variety of measurement techniques were used including: emission spectrography, wet chemistry, X-ray diffraction, optical microscopy, mass spectrometry, Orsat analysis, chemical analysis, $\mathrm{SO}_{2}$ analysis, standard combustion train, and optical emission spectroscopy. Finaliy, in the tests carried out probe wall temperatures ranged from 250-1250 F and gas temperatures from $1100-1700 \mathrm{~F}$.

Combustion Engineering, Inc., Windsor, Connecticut

Plumley, Accortt, and Roczniak (References 77-78) reported on the development of probes to study both deposition and corrosion in coal-fired combustion systems in laboratory as well as field settings. The major purpose of these studies was to investigate selected commercial and advanced experimental materials and coatings for advanced power cycles.

The laboratory test program utilized the Combustion Engineering Solid Fuel Burning Test Facility (SFBTF). The test furnace consisted of a refractory-lined, 30-in.-ID cylinder $12.5 \mathrm{ft}$ high. Flue gases leave the combustion zone, travel up the furnace, and are discharged at a right angle into a 141-in.2 horizontal superheater duct. This duct was designed to simulate the superheater-reheater section of a commercial boiler. Several air-cooled probes, each $8 \mathrm{in.}$ long and $1.5 \mathrm{in}$. in diameter, were used to simulate superheater tubes. The probes were inserted vertically into the duct and were located between 18 and 92 in. downstream from the furnace outlet. Each probe consisted of 11 coupons or segments made in the form of threaded rings which were screwed together to form the probe. The spacing between 
probes in any of the duct sections was kept at an 8-in. center-to-center distance throughout the tests. Probe metal temperatures were maintained in the 1200 to $1800^{\circ} \mathrm{F}$ range by controlling the air flowrate through the probe using the temperature control system shown in Fig. 3-24. Of the 11 segments, one was made in the shape of an end cap. Several of the remaining rings were drilled with 1/16-in. holes outward through the inside diameter. Thermocouples were inserted in these holes with the leads extending out the back upper end of the probes. The center thermocouple on each probe was used to regulate the air flow which controlled the probe surface at the desired temperature. The first segment of each probe was screwed into a holder. A 5/8-in. OD air line ran through both the shank and coupons distributing cooling air to the inside of the probe. The air passed through 1/16-in. 00 holes located around the periphery of the air line, turned through 180 degrees, and then exited through the top of the probe. Each probe was maintained at a prescribed surface temperature through on/off operation of two solenoid valves on each air circuit which were connected to the controller set at the desired temperature. Feedback from the control thermocouple actuated the solenoid valves and allowed air to enter the probe or to interrupt the flow, depending on whether the probe temperature was above or below the set point. Manual bypass on the air circuit was also available for operation during an electrical failure or solenoid burnout.

Field tests were carried out in actual operating utility stcam gencrators conducted in the superheater-reheater zone of the boiler. However, the four test probes used for the field tests were somewhat larger than those used in the laboratory investigations. A schematic drawing of the field test probe, including an enlarged drawing of an individual segment, is shown in Fig. 3-25. Each probe consisted of a total of 28 such segments of selected alloys threaded together (or held in tension) to form an 8-ft. probe which had a 2-in. OD. For the field tests, exposure of the probes was carried out in pairs $(1150-1450 \mathrm{~F}$. $1400-1700 \mathrm{~F})$ to cover the temperature range of interest. The high-temperature field probes consisted of two sections as shown in Fig. 3-25: (a) the air-cooled test section, and (b) the water-cooled section. The water-cooled section served to hold and extend the test-section end of the probe into the boiler and to supply cooling water up to the sample section. The flow of water 


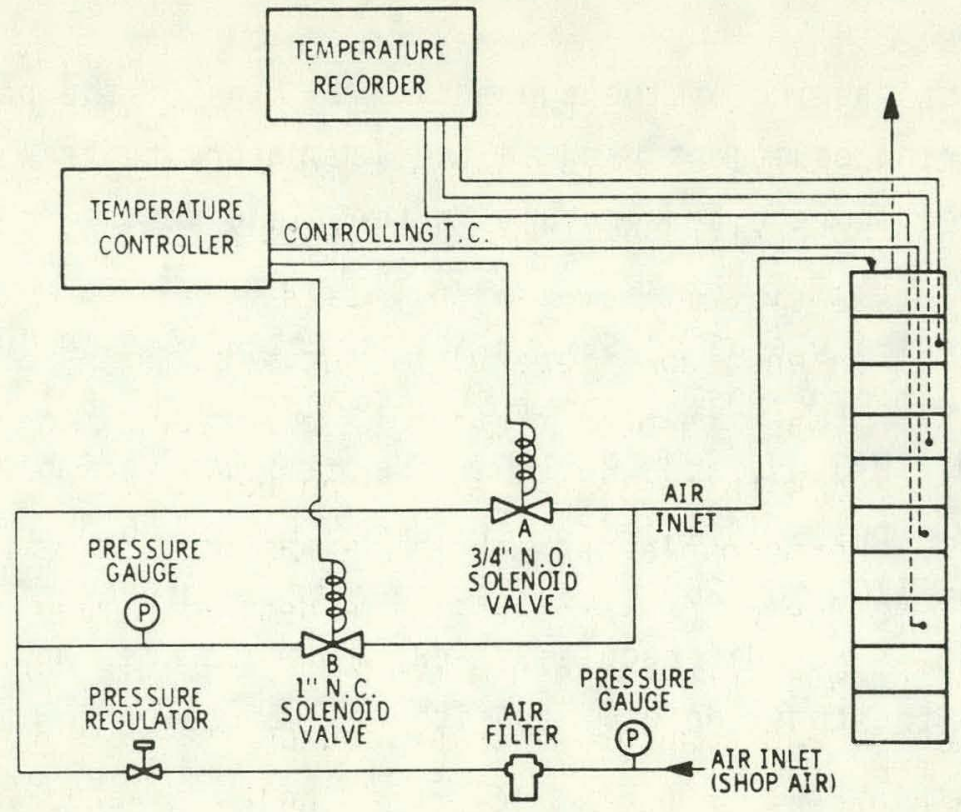

Figure 3-24. Schematic Drawing of Temperature Control System for Combustion Engineering Solid Fuel Burning Test Facility (Reference 77)

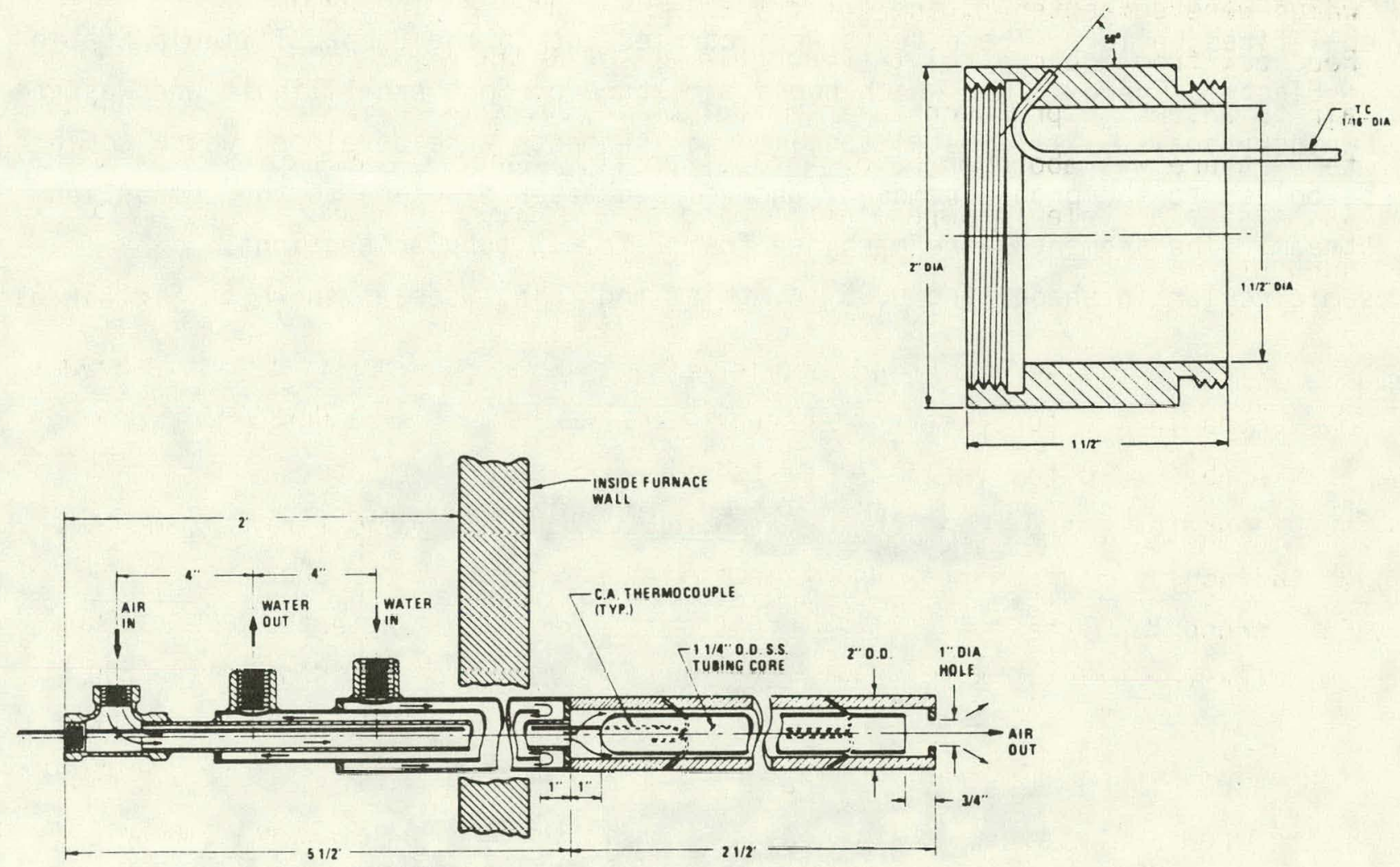

Figure 3-25. Combustion Engineering Field Test Deposition Probe Showing Individual Segment Detail (Reference 77) 
was fixed to prevent sagging of the supporting section of the probe. The control and monitoring equipment used in the laboratory tests was also used to modulate the desired surface temperature in the field tests.

Tests were carried out using several different alloys including Alloys 316 SS, 310 SS, Sandvik 12R72, 802, Inconel 617, T-22, Inconel 671, 188, Incoloy $800 \mathrm{H}$, Inconel $690, \mathrm{TP}-310 \mathrm{H}$, and TP-316H. The range of variables covered in the laboratory/field tests included: gas velocities of 56.8 to $63.8 \mathrm{ft} / \mathrm{sec}$, gas temperatures of 1100 to $2260 \mathrm{~F}$, and surface temperatures of 995 to $1900 \mathrm{~F}$. Electron microprobe, X-ray diffraction, $X$-ray fluorescence, and chemical analysis were used to study the ash deposits and corrosion.

\section{Electric Energy, Inc., Joppa, Illinois}

Koopman, et al. (Reference 79) reported on the development of a probe to study corrosion and deposition in the superheater and reheater reqion of a coal-fired boiler. These tests were carried out in the Joppa, Illinois, Station of Electric Energy, Inc. Which burns a mixture of Southern Illinois and Western Kentucky coals. Small metal specimens or segments were developed which could be bolted to the probe, removed, and weighed after exposure to the combustion stream. The segments were machined from 2-in. ID tubular sections, semicircular in shape, and $0.25 \mathrm{in}$. thick and $1 \mathrm{in}$. wide as shown in Fig. 3-26.

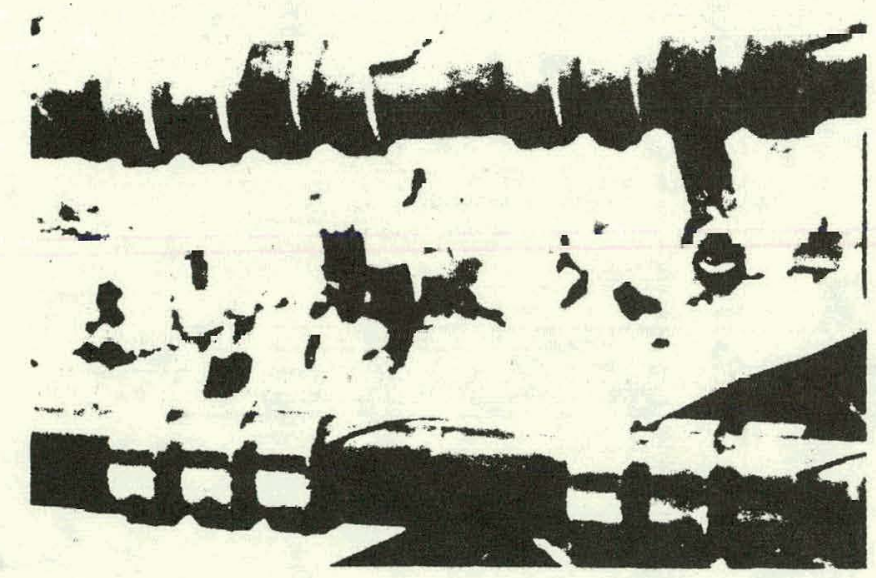

Figure 3-26. Electric Energy, Inc. Deposition Probe Before and After Exposure (Reference 79) 
The segments were bolted to a 2-in. OD probe by means of small lugs which had been welded to the probe. Chromel-Alumel thermocouples were placed in several of the segments in order to determine the metal temperature. A schematic diagram of the experimental setup is shown in Fig. 3-27. The apparatus consisted of three parts: (a) the probe to which the test segments were attached, (b) a mechanism for regulating the air flow to the probe in order to control the segment temperature, and (c) a temperature controller. The probe consisted of two sections as shown in Fig. 3-27, one of which was water cooled and also served as an arm to support the second section of the probe which was air cooled. The test segments were attached to the air-cooled section in three groups, each group containing either three or four segments (see Fig. 3-26). Thus, the axial temperature gradient along the probe permitted the testing of a given alloy at several different temperatures during the course of a single test. Control of the air was achieved using a manually operated valve plus two bypass solenoid valves, activated by a temperature change of the centrally located thermocouple using a temperature controller for this purpose as shown in Fig. 3-27. Tests were conducted with probes located at the rear of the secondary superheater and at the rear of the finishing reheater. Three stainless steel alloys -- Types T-11, T-22, and 321 SS -- were tested using metal temperature, exposure time, coal composition, gas temperature, and coal

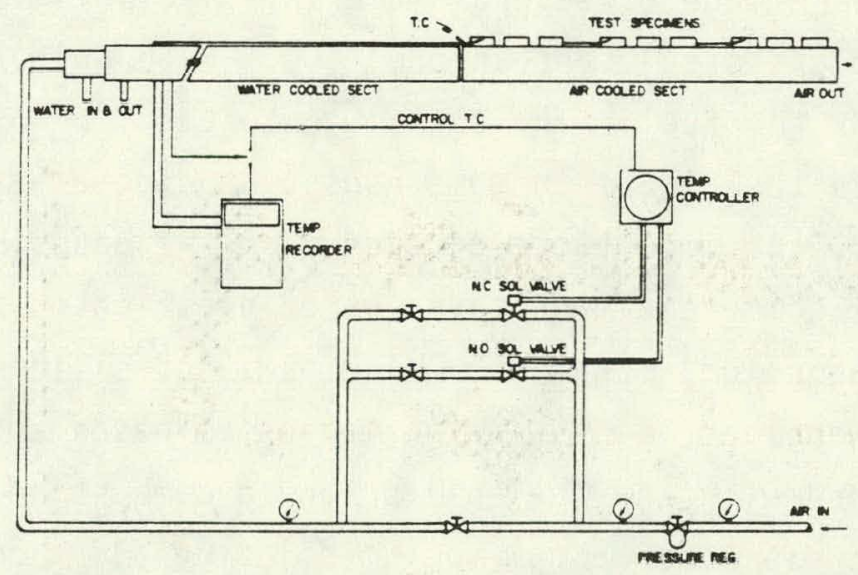

Figure 3-27. Schematic of Electric Energy, Inc. Deposition Probe Including Temperature Controller (Reference 79) 
fineness as parameters. In the tests carried out the gas temperature was about $1800 \mathrm{~F}$ with surface temperatures ranging from 850 to $1350 \mathrm{~F}$ for tests lasting up to $1000 \mathrm{hr}$.

\section{Battelle Memorial Institute, Columbus, Ohio}

Krause, et al. (Reference 80) evaluated the performance of fuel oil additives on simulated superheater surfaces in a laboratory scale combustor. The rectangular-shaped, stainless steel test section -- located in a duct downstream from the furnace -- was $24 \mathrm{in}$. long, $4 \mathrm{in}$. high, and 9 in. wide. Eight probes in the test section were mounted vertically in three rows on a 3 -in. staggered layout. Each of the dir-cuoled probes was 2 ill. 1ung, 1 in. in diameter, and fitted with lap joints for easy removal. A temperature control system, which used a thermocouple embedded in the tubewall to measure the probe surface temperature, was utilized to maintain the constant wall temperature boundary condition.

For the tests conducted, the gas temperature ranged from 1673 to $1947 \mathrm{~F}$, for a gas velocity of $22.7 \mathrm{ft} / \mathrm{sec}$, with the surface temperature of each probe maintained at $1100 \mathrm{~F}$. Thermocouples were used to measure both gas and surface temperatures. The probes -- analyzed for both corrosion and deposition atter the 50-hr tests -- were made of several materials including Alloys T-11 and T-22, Typc 34l stainless steel, and Inconel 600. High sulfur, high vanadium No. 6 oil was used as the fuel. The sodium content of the 0il, normally at $35 \mathrm{ppm}$, was increased to $325 \mathrm{ppm}$ in some runs by adding a $\mathrm{NaCT}$ emulsion to the oil in order to study the importance of sodium on the gas-side fouling process. In addition, several commercial additives were investigated including preparations with maqnesium, manganese, aluminum, and silicon. However, most of the experiments were carried out using magnesium-based additives. The additives were blended with the fuel oil prior to combustion using a high-speed mixer. In all cases with the $35 \mathrm{ppm}$ sodium oil, the addition of a MgO additive reduced the bond strength. However, when the sodium concentration was increased to $235 \mathrm{ppm}$, the deposit strength was actually increased with the addition of MqO-based additives. 
Gaseous species monitored included $\mathrm{O}_{2}, \mathrm{CO}_{2}, \mathrm{SO}_{2}$, and $\mathrm{SO}_{3}$ using the electrochemical cell method, EPA Method 6, and chemical analysis. A unique device was constructed to obtain a relative measure of the deposit bond strength. This device consisted of a knife-edged blade attached to a counterbalanced lever arm. A probe sample with its oil ash deposit was held in place below the knife-edge so that the blade could be brought to bear against the deposit along a tangent to the specimen. Force was applied above the knifeedge by successive addition of water to a container mounted on the lever arm. Thus, the weight of the water required to chip the deposit from the sample surface provided a semi-quantitative measure of the deposit bond strength.

\section{Solar Turbines Incorporated}

Solar Turbines Incorporated recent ly completed a study of the gas-side fouling and corrosion tendencies of exhaust gases in an aluminum melting furnace, Russe11, et al. (Reference 81). The exhaust gases from the aluminum reclamation furnace resulted from the combustion products of natural gas or Diesel fuel and excess air, along with those additives to the melt required to flux or otherwise dissipate the surface aluminum oxide, $\mathrm{Al}_{2} \mathrm{O}_{3}$. Such a gas stream can cause severe deposition and corrosion problems.

A test chamber -- 60 in. high, with a 3.5-in. by 9.0-in. test section -was attached to the side of the exhaust stack in the melting furnace. The test section was sufficiently large to allow the simultaneous testing of up to eight 0.75-in.-diameter metal probes and two 1.00-in.-diameter ceramic probes. Twenty-one different materials were tested including superalloys, stainless steels, and ceramics. The stainless steels included Types SA-28, 20CB3, 310, 321 , and $317 \mathrm{~L}$. The superalloys tested included Hastelloy G and H, INCO 625, 800, 690, and 825, and INCO 671/80011 Clad. Finally, the ceramics tested were NC-430, Hexaloy SA(A), SA(B), and KX-01, Coors SiC, TiB2"MSRN-T", TiB2"MSCM-TA", and Cryston. Except for two single material probes, all metal probes consisted of five or six different alloys as indicated in Fiq. 3-28. The metallic materials were butt-welded to form probes about $30 \mathrm{in}$. long which were mounted vertically in the test section. The hot gases from the stack entered the test section; flowed across the assembled probes, turned through 90 degrees, flowed 


\section{Cooling} Air Inlet

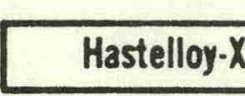

Hastelloy-G

Superalloy Probes

INCO 825

INCO 625

INCO 690

\section{Cooling} Air Inlet

\begin{tabular}{|l|l|}
\hline SA-28 & $20 C B 3$ \\
\hline
\end{tabular}

$20 C B 3$

310

321

317

\section{Stainless Probes}

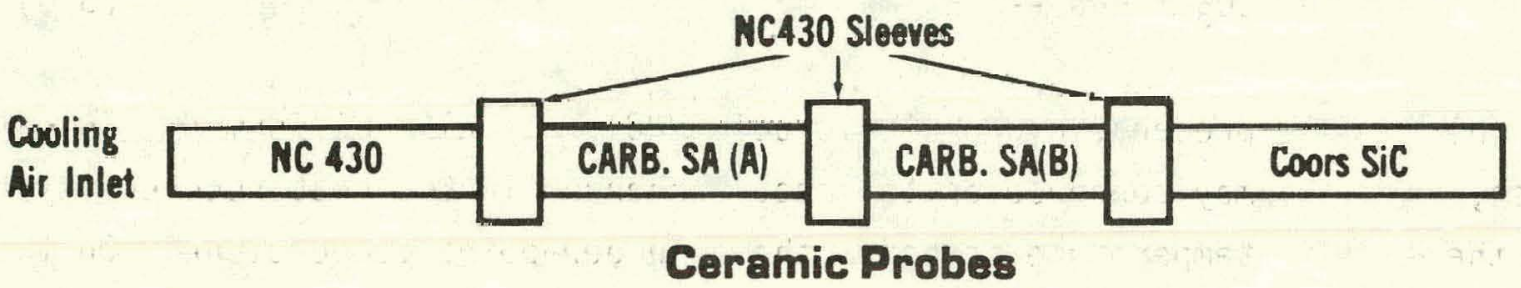

Figure 3-28. Typical Arrangement of Materials in Solar Turbines Incorporated Study (Reference 81)

longitudinally along the probes, exited from the test section, and then returned to the stack. The metal tubes were pre-oxidized for $100 \mathrm{hr}$ at $177 \mathrm{~F}$ in air to preform an initial cro protective oxide film to resist corrosion.

Several tests were conducted ranging from 315 to $2448 \mathrm{hr}$. Two thermocouples were installed on each probe and used to set the cooling air flowrate and hence the desired surface temperature of each probe. Desired probe wall temperatures ranged from 1200 to $2100 \mathrm{~F}$, the latter for ceramics which were not cooled during the tests. However, owing to the cyclic nature of the furnace firina, the probe surface temperatures cycled significantly. For example, it was desired to test the probe with the stainless steel materials at approximately $1700 \mathrm{~F}$. Huwever, the surface temperature for this probe varied between about 1400 and $1800 \mathrm{~F}$, with one excursion reducing the surface temperature to just below $1000 \mathrm{~F}$. Deposit and corrosion analyses were carried out using scanning electron microscopy, energy dispersive X-ray analysis, $\mathbf{X}-r$ ay flurescence, atomic absorption, and chemical analysis. 


\subsection{ACID CONDENSATION PROBES}

When a fuel containing sulfur is burned with excessive air, not all of the sulfur is converted to sulfur dioxide. Some of it is converted to sulfur trioxide which combines with water vapor in the gas to produce sulfuric acid vapor. The reactions of interest include

$$
\begin{aligned}
& \mathrm{S}+\mathrm{O}_{2} \rightarrow \mathrm{SO}_{2} \\
& \mathrm{SO}_{2}+1 / 2 \mathrm{O}_{2} \rightarrow \mathrm{SO}_{3} \\
& \mathrm{SO}_{3}+\mathrm{H}_{2} \mathrm{O} \rightarrow \mathrm{H}_{2} \mathrm{SO}_{4}
\end{aligned}
$$

If chlorine is present, hydrochloric acid, $\mathrm{HCl}$, may also be formed. In either case, the acid may condense on the heat exchanger in the heat recovery system if the surface temperature is below the acid dew-point temperature. On the surface it can mix with soot and other particulate matter to form acid smut. In addition to fouling the heat exchanger, the condensed acid can also cause severe corrosion of the metal surfaces. A number of instruments have been developed to measure acid condensation rates, some of which are available commercially. Pure acid condensation is, strictly speaking, not a type of fouling because an insulating layer of material is not actually deposited onto the heat-transfer surface. Nevertheless, because of the significant importance of acid condensation and its tendency to produce acid-smut-type deposits in low-temperature heat recovery systems, four acid condensation probes are discussed in this section. However, it should be emphasized that the treatment here is limited to four typical devices and does not represent a comprehensive review of acid condensation probes.

\section{Central Electricity Research Laboratories, Leatherhead, United Kingdom}

Alexander, et al. (Reference 82) used an air-cooled probe to measure the acid deposition in oil-fired-boiler flue gases. The air-cooled probe, similar to that described in References 39-40, was $8 \mathrm{ft}$ long and $1 \mathrm{in}$. in diameter. In order to minimize corrosion of the probe, it was constructed of austenitic stainless steel. The cooling air passed through the inside of the probe and, for design simplicity, was discharged directly into the flue gases. The wall 
temperature was essentially linear along the length of the probe, with surface temperatures ranging from 175 to $332 \mathrm{~F}$ for the results reported. Below $200 \mathrm{~F}$, especially for high-deposition rates, the probe surface was observed to be damp with particles of dust adhering to it. Although the tests ranged from 15 to 120 min. in length, tests of $30 \mathrm{~min}$. were found to be of sufficient duration to minimize errors due to the initial warm-up period. Within the limits of experimental error, the acid deposited at a given probe-wall temperature was directly proportional to the sample period and to the $\mathrm{SO}_{3}$ concentration in the flue gases. Detailed chemical analyses of the deposits showed that the material collected at wall temperatures below the acid dewpoint temperature consisted primarily of iron, chromium, and nickel sulfates -- the products of corrosion of the metal surface by the sulfuric acid. In general, only small quantities of sodium and vanadium oxides, derived from the fuel oil ash, were present.

\section{She11 Research Limited, Thornton Research Centre, Chester, United Kingdom}

Ross (Reference 83) discusses a cylindrical probe developed by Shell Research at the Thornton Research Centre in the United Kingdom to measure sulfuric acid deposition rates. The cylinder on which the acid was collected consisted of a gold-plated copper tube as shown in Fig. 3-29. The test section was taken to be the $z-i n$. portion of the cylindrical surface between the two

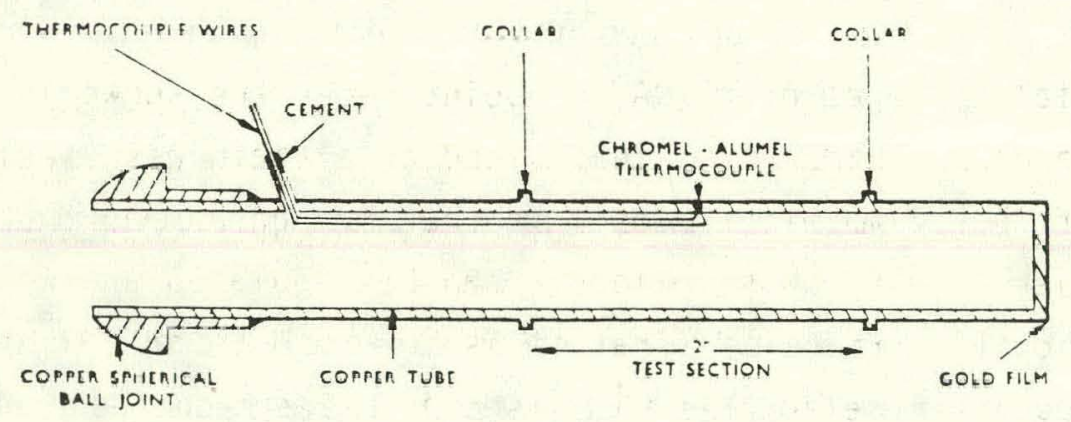

Figure 3-29. Acid Condensation Probe Developed by Ross (Reference 83) 
collars as shown. The cylinder was $0.0669 \mathrm{in}$. in diameter with the open end connected to a water-cooled condenser. The surface temperature of the probe was measured using a Chromel-Alumel thermocouple soldered. in the surface at. the mid-point of the test section. Tests were carried out using an experimental combustion rig.utilizing flue gases obtained by combusting a mixture of propane, air, and sulfur dioxide. The sulfuric acid content of the flue gases was varied by changing the relative portions of the three constituents. For a fixed gas composition the flue gas temperature, flue,gas velocity, and surface temperature were all varied during the, experiments. Prior to testing, the cylinder was degreased in acetone and allowed to dry. Inspection periods ranged from 5 to 20 min, after which the cylinder was quickly removed and allowed to cool. . The test section was washed free from acid with an aqueous solution, and the amount of acid was determined via chemical analysis. Experiments, were carried out with a gas temperature of $536 \mathrm{~F}$, a mass velocity of $3442 \mathrm{lb} / \mathrm{hr}-\mathrm{ft}^{2}$, and surface temperatures of 185 to $298 \mathrm{~F}$. With, the exception of surface temperatures below $212 \mathrm{~F}$, the acid condensation rates were predicted within \pm 15 percent.

\section{Land Pyrometers Limited, Dronfield, Sheffield, United.Kingdom}

More recently, Land (Reference.84) developed a theory for acid deposition and compared his predictions with experimental results obtained using the well-known British Coal Utilization Research Association (BCURA) dew-point meter developed in the United Kingdom around 1950. A brief description of the BCURA meter will be given here.

The pssential features of BCURA dew-point meter are shown in Fiq. 3-30. It consists of a glass thimble set in the end of a stainless steel probe. The outer surface of the thimble is exposed to the flue gases and the inner surface is cooled by a jet of air, whose velocity can be regulated and which flows as indicated. The outer surface temperature is measured using a Platinum Rhodium thermocouple whose junction is fused into the glass and then ground to expose both the jet and a short length of wire on either side. The junction also forms one electrode of a conduction cell whose other electrode is a concentric platinum ring, also fused flush with the surface. A potential of .10 volts at a frequency of $10 \mathrm{~Hz}$ is applied to the electrodes and the meter in 

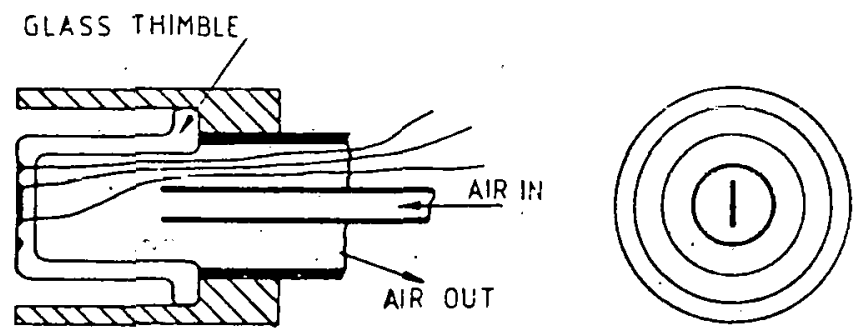

Figure 3-30.' Essential Features of the BCURA Acid Condensation Probe (Reference 84)

the modern electronic unit can be switched to measure either the current. ... between the electrodes or the rate of change of current, which is usually called the rate of buildup. Another meter reads the surface temperature. The probe is inserted into the flue gas and the cooling air flowrate is increased until acid deposition is initiated on the glass surface. The air flowrate is requlated to maintain a constant current of about 100 amperes across the electrodes. When the current has attained a steady-state value, the temperature measured by the thermocouple-is the acid dew-point temperature of the gas. Once the dew-point temperature is known, the rate of acid deposition can be calculated provided that the gas velocity and surface temperature are also known. It should be pointed out that the BCURA meter cannot be used, to determine the deposition rate of water vapor condensation. The reason for this limitation is that whereas the acid forms a thin film on the glass, water is. deposited in dropwise condensation which can run across the conductivity cell without forming a continuous conduction path. Results were reported for the deposition of sulfuric acid from the combustion gases in an industrial boiler. The fuel burned was oil with 30 percent excess air. For these tests, the probe wall temperature ranged from 176 to $302 \mathrm{~F}$ for flue gas temperatures of 320 to $554 \mathrm{~F}$. 
Technical Center of Industries Aerauliques at Thermiques, Villeurbanne Laboratory, France

Dietz and Marchal (Reference 85) carried out an investigation of the deposition of $\mathrm{H}_{2} \mathrm{O}, \mathrm{H}_{2} \mathrm{SO}_{4}$, and particulate matter from the combustion products of a heavy fuel oil. Tests were made in a small-scale laboratory setup. The 0.787-in. diameter collection tube, or probe, was made of stainless steel and was installed inside a vertical tube of 7.87-in.-diameter. The probe was cooled by passing compressed air inside the stainless steel tube with the combustion gases flowing in a counterflow direction through the annular portion of the assembiy. The major parameters of interest in this study included the: (a) concentration of $\mathrm{H}_{2} \mathrm{O}$ (9.5 to 10.7 percent), $\mathrm{H}_{2} \mathrm{SO}_{4}$ (4.2 to $5.9 \mathrm{ppm}$ ), and particulate matter - - primarily soot $\left(0.00287\right.$ to 0.632 grains $\left./ \mathrm{ft}^{3}\right)$ in the gas stream, (b) gas temperature (342 to $410 \mathrm{~F}),(\mathrm{c})$ surface temperature (113 to $293 \mathrm{~F})$, and (d) gas velocity $(26.3$ to $78.7 \mathrm{ft} / \mathrm{sec})$. The experimental deposition rates were in reasonably good agreement with the predicted values for low-particle concentrations. However, at high-particle loadings the measured deposition rates exceeded the predicted values. Finally, the probe surface temperature was found to be a far more important parameter than the gas temperature in this study.

\subsection{RECLNT DEVELOPMENTS IN THE UNITED KINGDOM}

- A significant amount of work related to gas-side fouling measuring dcviccs has been"carried out in the IInited Kingdom as discussed in Section 3.5. Additional heat-recovery-related applications were identified by W.H. Thielbahr, Technical Monitor for the present study, through contacts with participating members of the International Energy Ayency (IEA). Some of this work, which involves both the academic and industrial sectors in the United Kingdom, has recently been completed while some is still in progress.

The major United Kingdom effort in gas-side fouling in heat-recovery applications is composed of three tasks: (a) the fouling of finned-tube heat exchangers, (b) the removal of particulate matter from dirty gas streams, and 
(c) foulant characterization. These tasks are being performed by personnel at Harwell AERE and the University of Birmingham, Ricardo Consulting Engineers, and the National Engineering Laboratory (NEL), respectively. The following description of the gas-side fouling effort in the United Kingdom is based on meetings and discussions with those technical personnel directly responsible for that research (Reference 86). General information, as well as specific details on gas-side fouling probe design and operational experience, is presented in this section.

\section{Fouling of Finned Tube Heat Exchangers}

The first task to be described, the fouling of finned tube heat exchangers, was designed to address the problem of gas-side fouling on a mechanistic level, drid is divided into three subtasks. These, subtasks are: (a) fouling by submicron particulates less than $1 \mathrm{\mu m}$ in diameter, (b) fouling by supermicron particulates, 1 to $30 \mu \mathrm{m}$ in diameter, and (c) fouling by frosting. The fouling-by-frosting subtask will not be discussed here because it does not result from a combustion gas.stream.

The submicron fouling subtask being performed at Harwell will address Lhermophorésis, 1.e., thermal transport mechanisms, and electrophoresis, i.e., the effect of electrostatic charge on particle migration. The experimental work relating specifically to this effort had not been initiated at the time of this writing. However, as part of this task, a small fouling probe was constructed at Harwell for testing in Diesel exhaust gases which contain: submicron particulates. The Harwell fouling probe (HFP) was designed torgather data complementary to that being obtained using the NEL fouling probe, which was discussed in Section 3.5 and which will be dealt with further in this section, in short duration tests at the Ricardo installation. The HFP configuration is a simple $U$-tube supported by a single central rod running the length of the device. The air-cooled probe was constructed from tubing having eight fins per inch with exhaust gas temperatures determined by means of thermocouples mounted in the support rod. This probe was operated adjacent to the NEL probe in the exhaust of a stationary Diesel engine for approximately $50 \mathrm{hr}$ on a variety of Diesel fuels. Several lessons were learned about fouling 
probe design, operation, and usefulness of the test results obtained. For example, to determine the overall heat transfer coefficient -- from which the fouling factor, or resistance, may be determined -- the free-stream gas velocity near the probe is required. However, in the case of the HFP, the probe blocked a portion of the flow but did not extend across the entire duct. Therefore, the gas velocity near the probe was undoubtedly lower than the average gas velocity upstream of the probe because of gas bypassing around the probe. However, since the gas velocity was not measured during the tests, subsequent wind tunnel flow measurements must be carried out to obtain this information. Another problem with this probe was the lack of knowledge of fin and tubewall temperatures. This experience emphasizes the fact that a consistent set of measurements -- including" gas velocity, gas temperature, surface temperature, and heat flux are required if gas-side fouling resistances are to be determined.

The second subtask, fouling by particulates .1 to $20 \mu \mathrm{m}$ in diameter, is being performed at the University of Birmingham and is designed to evaluate the mechanisms by which deposition and the subsequent fouling buildup occur in this particle size range. The experimental apparatus being used at the University of Birmingham consists of a two-row, water-cooled finned tube heat exchanger which is installed in a one-foot-square vertical wind tunnel. The air velocity and temperatures are variable from 2.5 to $5.5 \mathrm{ft} / \mathrm{sec}$, and ambient to $122 \mathrm{~F}$, respectively. The air flowing through the wind tunnel is loaded with predetermined quantities of calcium carbonate dust, 1 to $30 \mu \mathrm{m}$ in diameter. This work is closely related to a parallel effort where University of Birmingham personnel are modeling variations in the flow field through a heat exchanger. In this study, the optimum placement of tubes is being investigated to minimize flow field variations within the heat exchanger. This effort is supported by a means of a physical model which is instrumented for very precise flow measurements. Gas-side fouling is clearly a very complex phenomena and involves interactions among the various parameters including those related to the geometry. Work on other heat exchanger geometries is planned with the objective of establishing some of these relationships. 


\section{Particulate Removal}

In the second task, performed by Ricardo Consulting Engineers, the removal of particulates contained in Diesel engine exhausts - - prior to encountering any heat exchange equipment -- was addressed. Two methods of particulate removal were investigated: electrostatic precipitation and filtration. Conventional electrostatic precipitation techniques removed approximately 70 percent of the particulate matter present. Filtration by a ceramic felt material (95 percent $\mathrm{Al}_{2} \mathrm{O}_{3}$ and 5 percent $\mathrm{SiO}_{2}$ by weight) proved to be approximately 90 percent efficient. These filters were operated continuously and cleaned in situ by a reverse pressure pulse.

\section{Foulant Characterization}

The final, and most pertinent task with respect to this report, is the foulant characterization work being performed at the National Engineering Laboratory (NEL), East Kilbride, Glasgow, Scotland. The NEL probe was designed as a mass accumulation device, and has been successfully used to determine gas-side fouling deposition rates as a function of temperature with a minimum disruption of the operation of the system being investigated. The NEL probe has been employed in installations where heat-transfer equipment is already in place, i.e., Diesel engine power generating stations, as well as in systems where a potential application for heat recovery equipment exists.

The NEL probe -- shown in Figs. 3-12, 3-13, and 3-14 and described " briefly in Section 3.5 (References 42-43) -- is a coaxial device, approximately $6 \mathrm{ft}$ in length and $1.0 \mathrm{in.}$ in diameter, with a split cylindrical mass accumulation specimen, or segment, located at the end of the probe. The coaxial probe consists of two concentric tubes which allow the coolant to flow axially down the center tube to the specimen, provide cooling for the specimen, and then return through the annular portion of the concentric tubes. The coolant can be either air or water, depending on the amount of heat removal required. The specimen, where the gas-side fouling deposit actually occurs, is a two-piece axially split cylinder, about 2 in. in length. These two halfcylinders are connected to the probe to form a complete cylinder via 
compression by nuts threaded on the probe. Each half cylinder is drilled to accept a sheathed thermocouple for measuring the surface temperature which is also used to facilitate manual adjustment of the coolant flowrate. Both the inlet and outlet coolant temperatures are measured. During a typical operation of the probe, several pieces of auxiliary equipment are also used. These devices include a pitot tube, acid dew-point meter, gas sample unit, and particulate samplers. All of the experimental data are collected by a computerized system for tabulation and analysis. The NEL probe is usually operated at a specified surface temperature for a predetermined period of time and then withdrawn from the exhaust gas stream. The mass accumulation portion, of the probe is then removed for measurement of the deposit weight and thickness, and for subsequent chemical analysis of the deposit. A new, preweighed specimen is then installed and the probe is reinserted for further testing.

The first step in the data reduction procedure is to determine the mass of the deposit which is collected for a specific length of time and surface temperature. Holding the surface temperature constant and varying the duration of the tests yields a plot of deposit mass per unit area verșus time at a constant surface temperature. A series of experiments of this type will thus generate a family of curves, each identified by the surface temperature of the probe. By plotting the slope of each constant-surface-temperature curve versus surface temperature, it is possible to determine the rate of deposition as a function of surface temperature. In addition to this data reduction procedure, post-test analyses are carried out on samples of the exhaust gases, fouling deposits, and in the case of Diesel engine applications the fuel being used. Analytical methods currently being employed include standard gas and liquid chromatography, high pressure liquid and gel permeation chromatography, and chemical analysis: These methods have been used to analyze and compare the chemical components of the fouling deposit to those of the fuel and, in Diesel applications, to those of the crankcase oils as well.

The design of the NEL probe, specifically the split cylindrical test specimen, lends itself to the collection of gas-side fouling deposits. In addition, this configuration makes it easy to interchange and test a variety of 
different materials. The following list summarizes the experience gained by NEL personnel during the design and initial operation of the NEL fouling probe:

(a) The successful design and operation of a gas-side fouling probe must be simple to facilitate use in the field under non-optimum conditions.

(b) The determination of the deposition rate and the gas-side fouling factor, $R_{f}$, in situ would be advantageous. However, the NEL massaccumulation-type probe is not designed for such measurements. In order to determine $R_{f}$, the heat flux, $q_{w}^{\prime \prime}$, must be known. Unfortunately, in order to measure $q_{w}^{\prime \prime}$, the change in coolant temperature across the specimen must be greater than that achieved in the current design:

(c) The NEL cooling scheme could be improved. In the current design, depending on the gas and surface temperatures, water tends to overcool while air tends to undercool. This problem could possibly be overcome through the use of a temperature controller.

(d) The split specimen is easy to remove in the field, even at elevated temperatures. This geometry also allows for separation of the upstream and downstreaiin füuling efrecls.

(e) Automatic data acquisition equipment is essential for the surressfur long-term operation of the probe.

(f) The ability to perform visual observations while the probe is in place would be beneficial but such inspections are difficult in dirty gas environments, especially at elevated operating temperatures.

(g) Additional measurements of surface and coolant temperatures should be made to provide greater reliability and accuracy in the determination of these quantities. 
(h) In some cases the use of some variable other than the overall heat transfer coefficient to detect the buildup of gas-side fouling deposits -- for example, the pressure drop -- may be advantageous.

(i) The collection of gas-side fouling déposits cannot ștand alone. Measurement of gas velocity, gas temperature, surface temperature, and gas composition -- including particle concentration, composition, and size distribution -- must accompany the use of the probe. 
SECTION 4

GAS-SIDE FOULING PROBE SURVEY MATRIX

The information presented in Section 3 in descriptive form -. plus additional details if available -- is summarized and presented in Tables 4-1 through 4-32. The probe-related information is given in as much detail as possible. Gas characterization and deposit characterization information is also reported; but generally in less detail. Emphasis is placed on actual experimental data reported in the pertinent references.

The uniform format for each measuring device used in Tables 4-1 through 4-32 includes first the organization which was primarily resporisible for the work. Next, the probe type, the type of fuel(s) tested, and the secondary fluid (if any) used to cool the probe are listed. The probe geometry. is specified along with the materials tested, whether the materials are interchangeable, and the location(s) where the testing took place is identified. A "Yes" beside heat flux indicates that either the primary or secondary side heat flux was measured, while a "Yes" béside heat balance. indicates that both the gas-side and cooiing-side heat flux were measured. Next, the range of gas and probe wall or surface temperatures to which the probe was subjected is indicated as well as whether the probe wall temperature was controlled, either manualiy or automatically. The type of thermal boundary condition, i.e., constant wall temperature, variable heat flux, etc. is specified. It should be pointed out that in many cases where the surface temperature varied along the probe, the local wall temperature was constant with time. The maximum sampling period, or time during which the probe was actually exposed to the combustion gas stream, is indirated next. This parameter gives a good indication as to the robustness of the probe. Finally, the gas-side velocity, turbulence intensity, and fouling factor are indicated, the latter two with a "Yes" or "No." A "--" beside any item indicates that the parameter listed was not measured. 
Gas characterization and deposit characterization information is presented as the last two major items in Tables 4-1 through 4-32. Gas characterization includes fuel analyses, gaseous components, dew-point temperatures, particle size distribution, particle composition, particle concentration, and excess:-air. Deposit characterization includes deposit constituents, morphology, and melting temperature; an indication as to whether corrosion analysis were carried out; and the magnitude of the deposit mass. Finally the measurement techniques employed to carry out the gas and deposit characterization are given, with the abbreviations or acronyms defined in the Nomenclature. 
Table 4-1. Gas-Side Fouling Probe Survey Matrix:

Central Electricity Research Laboratories, Leatherhead, Surrey, United Kingdom

\begin{tabular}{|c|c|}
\hline Reference (s) & Northover and Hitchcock (27) \\
\hline Type of Probe & Heat Flux \\
\hline Fuel & $0 i 1$ \\
\hline Secondary Fluid & Not Applicable \\
\hline $\begin{array}{l}\text { Probe: } \\
\begin{array}{l}\text { o Geometry } \\
0 \text { Wall Material/ } \\
\text { Interchangeable } \\
\text { o. Location }\end{array}\end{array}$ & $\begin{array}{l}\text { Radial Disc } \\
\text { Corronel } 230 \text { Disc, T2 Body/Yes } \\
\text { Boiler }\end{array}$ \\
\hline Heat Flux & Yes (Not Reported). \\
\hline Heat. Balance. & -- \\
\hline $\begin{array}{c}\text { Temperature: } \\
0 \text { Gas } \\
0 \text { Probe Wall } \\
\text { O. Probe Wall }\end{array}$ & $\begin{array}{l}\sim 2800 \mathrm{~F} \\
570-1200 \mathrm{~F} \\
\text { No }\end{array}$ \\
\hline Thérmal Boundary Condition... & Variable Heat Filux \\
\hline Maximum Sampling Period & 200 days \\
\hline $\begin{array}{lc}\text { Gas-Side: } & \ddots \\
\text { '0. Velocity } & \therefore \\
0 \text { Turbulence Intensity } & \\
0 \text {. Fouling Factor } & \end{array}$ & $\begin{array}{l}-- \\
-- \\
--\end{array}$ \\
\hline $\begin{array}{l}\text { Gas Characterization } \\
\text { 0. Fuel Analysis } \\
\therefore \text { Gaseous Components } \\
\therefore \text { o. Dew-Point Temperatures } \because \\
0 \text { Particle Size Distribution } \\
0 \text { Particle Composition } \\
\text { o. Particle Concentration } \\
\text { o. Excess Air } \\
\therefore \text { o. Measurement Techniques } \\
\end{array}$ & $\begin{array}{l}-- \\
-- \\
-- \\
-- \\
-- \\
-- \\
-- \\
--\end{array}$ \\
\hline $\begin{array}{l}\text { Deposit Characterization } \\
\text { o. Constituents } \\
\text { - Deposit Morphology } \\
\text { o Deposit Melting Iemperature } \\
\text { o Corrosion Analysis } \\
\text { 0. Deposit Mass } \\
\text { 0. Measurement Techniques }\end{array}$ & $\begin{array}{l}-- \\
-- \\
-- \\
-- \\
--\end{array}$ \\
\hline
\end{tabular}


Table 4-2. Gas-Side Fouling Probe Survey Matrix:

Central Electricity Research Laboratories, Leatherhead, Surrey, United Kingdom

\begin{tabular}{|c|c|}
\hline Reference $(s)$ & Neal, et al. $(28-29)$ \\
\hline Type of Probe & Heat Flux \\
\hline Fuel & Coal, 0 il \\
\hline 'Secondary. Fluid & Not Applicable \\
\hline 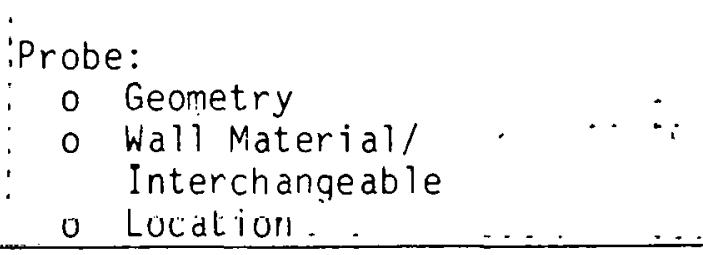 & $\begin{array}{l}\text { Guarded Cylinder (Fluxtube, Dometer }) \text {, } \\
1 \% \text { Chrome and } 0.5 \% \text { Molybdenum Steel, } \\
\text { Stainless Steel/Yes } \\
\text { Boiler. }\end{array}$ \\
\hline 'Heat Flux. & Yes. \\
\hline Heat Bailance & $\therefore$ \\
\hline $\begin{array}{l}\text { Temperature: } \\
\text { o lias } \\
\text { o Probe Wall } \\
\text { o Probe Wall, Control ..... }\end{array}$ & $\begin{array}{lll}\sim 2500 \mathrm{~F} & & \ddots \\
\text { Up to } 932 \mathrm{~F} & & \ddots \\
\text { No } & & \ddots \\
\end{array}$ \\
\hline Thermal Boundary. Condition ' & Variable Heat. Flux \\
\hline Maximum Sampling. Period & $2000 \mathrm{hr}$ \\
\hline $\begin{array}{l}\text { Gas-Side: } \\
\text { o Velocity } \\
\text { o Turbulence Intensity } \\
\text { o Fouling Factor }\end{array}$ & $\begin{array}{l}-- \\
-- \\
--\cdots \\
\end{array}$ \\
\hline $\begin{array}{l}\text { Gas Characterization } \\
\text { o Fuel Analysis } \\
\text { o Gaseous Components } \\
\text { o Dew-Point Temperatures } \\
\text { o Particle Size Distribution } \\
\text { o Particle Composition } \\
\text { o Particle Concentration } \\
\text { o Exccss Air } \\
0 \text { Measurement Techniques } \\
\end{array}$ & $\begin{array}{l}\because \cdots \\
\therefore \\
\therefore \\
\therefore \\
\therefore \\
\quad \cdot\end{array}$ \\
\hline $\begin{array}{l}\text { Deposit Characterization } \\
\text { o Constituents } \\
\text { o Deposit Morphology } \\
\text { o Deposit Melting Temperature } \\
\text { o Corrosion Analysis } \\
\text { o Deposit Mass } \\
\text { o Measurement Techniques }\end{array}$ & $\begin{array}{l}-- \\
-- \\
-- \\
-- \\
--\end{array}$ \\
\hline
\end{tabular}


Table 4-3. Gas-Side Fouling Probe Survey Matrix: University of Water loo, Waterloo, Ontario, Canada

\begin{tabular}{|c|c|c|}
\hline Reference $(s)$ & Chambers, et al. $(30-31)$ & \\
\hline Type of Probe & Heat Flux & $\because$ \\
\hline Fue?. & Coal & \\
\hline Secondary Fluid & Not Applicable & \\
\hline $\begin{array}{l}\text { Probe: } \\
\text { 0. Geometry } \\
0 \text { Wall Material/ } \\
\text { Interchangeable } \\
\text { o Location }\end{array}$ & $\begin{array}{l}\text { Radial Disc } \\
\text { Not Specified/Yes } \\
\text { Boiler }\end{array}$ & $\begin{array}{l}\ddots \\
\cdots\end{array}$ \\
\hline Heat Flux & Yes & \\
\hline Heat Balance & $\therefore$ & \\
\hline $\begin{array}{l}\text { Temperature: } \\
0 \text { Gas } \\
0 \text { Probe Wall } \\
0 \text { Probe Wall, Control }\end{array}$ & $\begin{array}{l}2500 \mathrm{~F} \\
392-1022 \mathrm{~F} \\
\text { No. } \\
\end{array}$ & $\begin{array}{l}\because \\
\cdots\end{array}$ \\
\hline Thermal Boundary Condition: . & Variable Heat Flux & \\
\hline Maximum Sampling Period & $22 \mathrm{hr}$ & \\
\hline $\begin{array}{l}\text { Gas-Side: } \\
\text { o Velocity } \\
\text { o Turbulence Intensity } \\
0 \text { Fouling Factor } \\
\end{array}$ & $\begin{array}{l}-- \\
-- \\
-\therefore\end{array}$ & $\begin{array}{l}\therefore \\
\therefore\end{array}$ \\
\hline 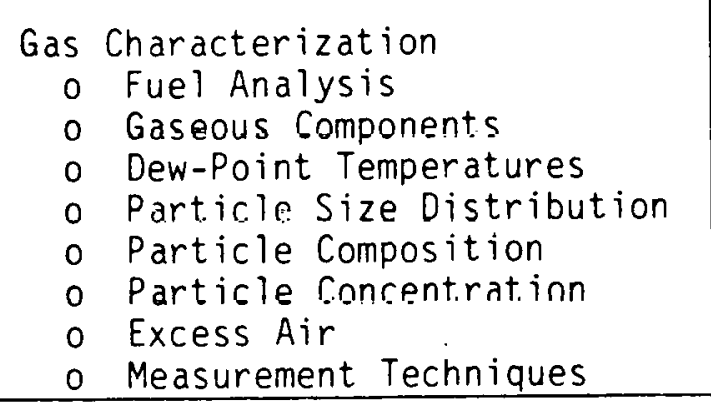 & $\begin{array}{ll}\text { Yes } & \\
-- & \ddots \\
-- & \\
-- & \\
-- & \\
-- & \\
\text { Not Specified }\end{array}$ & $\therefore$ \\
\hline $\begin{array}{l}\text { Deposit Characterization } \\
0 \text { Constituents } \\
0 \text { Deposit Morphology } \\
0 \text { Deposit Melting Temperature } \\
0 \text { Corrosion Analysis } \\
0 \text { Deposit Mass } \\
0 \text { Measurement Techniques } \\
\end{array}$ & $\begin{array}{l}\text { Yes } \\
\text { Yes } \\
\text { Yes } \\
-- \\
-- \\
\text { Not Specified }\end{array}$ & \\
\hline
\end{tabular}


Table 4-4. Gas-Side Fouling Probe Survey Matrix:

University of Sheffield, United Kingdom

\begin{tabular}{|c|c|}
\hline Reference (s) & Brown, et al. (32-33) \\
\hline Type of Probe & Mass Accumulation \\
\hline Fuel & Kerosene doped with $\mathrm{Na}, \mathrm{S}, \mathrm{V}$ \\
\hline Secondary Fluid & Air \\
\hline $\begin{array}{l}\text { Probe: } \\
\text { o Geometry } \\
0 \text { Wall Material/ } \\
\text { Interchangeable } \\
\text { o Location }\end{array}$ & $\begin{array}{l}\text { Cylinder: } d=1 \text { in., } L=3 \mathrm{ft} \\
\text { Stainless Steel/Yes } \\
\text { Laboratory Pilut-Scale Furnace }\end{array}$ \\
\hline Heat Flux & -- \\
\hline Heat Balance & -- \\
\hline $\begin{array}{l}\text { Temperature: } \\
\text { o Gas } \\
0 \text { Probe Wall } \\
0 \text { Probe Wall, Control }\end{array}$ & $\begin{array}{l}-- \\
752-1364 \mathrm{~F} \\
\text { Yes }\end{array}$ \\
\hline Thermal Boundary Condition . & Constant wall Temperature (Locally). \\
\hline Maximum Sampling Period & $10 \mathrm{hr}$ \\
\hline $\begin{array}{l}\text { Gas-Side: } \\
0 \text { Velocity } \\
0 \text { Turbulence Intensity } \\
0 \text { Fouling Factor } \\
\end{array}$ & $\begin{array}{l}\sim 20 \mathrm{ft} / \mathrm{sec} \\
\text { Six percent } \\
.\end{array}$ \\
\hline $\begin{array}{l}\text { Gas Characterization } \\
0 \text { Fuel Analysis } \\
\text { o Gaseous Components } \\
0 \text { Dew-Point Temperatures } \\
0 \text { Particle Size Distribution } \\
0 \text { Particle Composition } \\
0 \text { Particle Concentration } \\
0 \text { Excess Air } \\
0 \text { Measurement Techniques } \\
\end{array}$ & $\begin{array}{l}\text { Yes (Not Reported) } \\
\mathrm{O}_{2} \\
\mathrm{Na}_{2} \mathrm{SO}_{4}, \mathrm{~V}_{2} \mathrm{O}_{5} \\
1-2 \mu \mathrm{m} \\
-- \\
--: \\
\text { Less Lhin } 1.0 \text { percent to } 25 \text { percent } \\
\text { Not Specified }\end{array}$ \\
\hline $\begin{array}{l}\text { Deposit Characterization } \\
\quad 0 \text { Constituents } \\
0 \text { Deposit Morphology } \\
0 \text { Deposit Melting Temperature } \\
\therefore \quad 0 \text { Corrosion Analysis } \\
0 \text { Deposit Mass } \\
\text { o Measurement Techniques }\end{array}$ & $\begin{array}{l}\text { Yes } \\
\text { Yes } \\
-- \\
\text { No corrosion } \\
0.0097-0.0224 \mathrm{~g} \\
\text { IR, FP, CA }\end{array}$ \\
\hline
\end{tabular}


Table 4-5. Gas-Side Fouling Probe Survey Matrix:

Rheinisch-Westfalisches Elektrizatswerk AG, Federal Republic of Germany

\begin{tabular}{|c|c|}
\hline Reference (s) & He in (34) \\
\hline Type of Probe & Mass Accumulation \\
\hline Fuel & Brown Coal \\
\hline Secondary Fluid & Air/water \\
\hline $\begin{array}{l}\text { Probe: } \\
\text { o Geometry } \\
\text { o Wall Material/ } \\
\text { Interchangeable } \\
\text { o Location }\end{array}$ & $\begin{array}{l}\text { Cylinder: } d=1.34 \text { in., } L=1.97 \text { in: } \\
\text { Unspecified Metal, Ceramic/Yes } \\
\text { Research Rig }\end{array}$ \\
\hline Heat Flux & 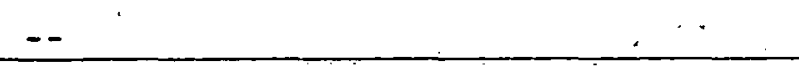 \\
\hline Heat Balance & -- \\
\hline $\begin{array}{l}\text { Temperature: } \\
0 \text { Gas } \\
0 \text { Probe Wall } \\
0 \text { Probe Wall, Control }\end{array}$ & 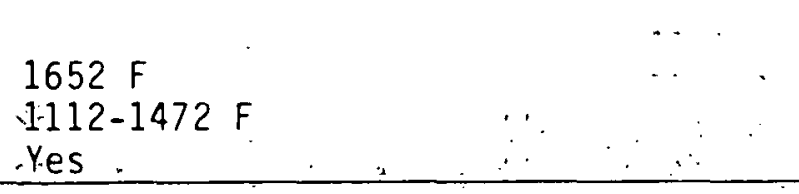 \\
\hline Thermal Boundary Condition... & - Constant Wall Temperature (Locally) \\
\hline Maximum Sampling Period & $60 \mathrm{hr}$ \\
\hline $\begin{array}{l}\text { Gas-Side: } \\
0 \text { Velocity } \\
0 \text { Turbulence Intensity } \\
0 \text { Fouling Factor }\end{array}$ & $\begin{array}{l} \\
-1 \\
-- \\
- \\
\end{array}$ \\
\hline $\begin{array}{l}\text { Gas Characterization } \\
0 \text { Fuel Analysis } \\
0 \text { Gaseous Compunents } \\
0 \text { Dew-Point Temperatures } \\
0 \text { Particle Size Distribution } \\
0 \text { Particle Composition } \\
0 \text { Particle Concerllation } \\
0 \text { Excess Air } \\
0 \text { Measurement Techniques } \\
\end{array}$ & \begin{tabular}{ll} 
Yes (Not Reported) \\
\hdashline \\
\hdashline \\
Yes
\end{tabular} \\
\hline $\begin{array}{l}\text { Deposit Characterization } \\
0 \text { Constituents } \\
0 \text { Deposit Morphology } \\
0 \text { Deposit Melting Temperature } \\
0 \text { Corrosion Analysis } \\
0 \text { Deposit Mass } \\
0 \text { Measurement Techniques } \\
\end{array}$ & $\begin{array}{l}\text { Yes } \\
\text { Yes } \\
\text { Yes } \\
\therefore- \\
\text { Yes (Mass Deposition Rate Reported) } \\
\text { CA, XRF, XRD }\end{array}$ \\
\hline
\end{tabular}


Table 4-6. Gas-Side Fouling Probe Survey Matrix:

David W. Taylor Naval Ship R\&D Center, Betnesda, Maryland

\begin{tabular}{|c|c|}
\hline Reference (s) & Rogalski $(35-36)$ \\
\hline Type of Probe & Mass Accumulation \\
\hline Fuel & No. 2 Diesel Fuel \\
\hline Secondary Fluid & Air \\
\hline $\begin{array}{l}\text { Probe: } \\
\text { o Geometry } \\
\text { o Wall Material/ } \\
\text { Interchangeable } \\
\text { o Location }\end{array}$ & $\begin{array}{l}\text { Cylinder: } d=1 \text { in., } L=4 \text { in. } \\
\text { Stainless Steel/No } \\
\text { Ship and Land-Based Gas Turbine Exhaust }\end{array}$ \\
\hline Heat. Flux & Yes (Secondary Fluid) \\
\hline Heat Bailance & $c_{c}$ \\
\hline $\begin{array}{l}\text { Temperature: } \\
\text { o Gas. } \\
\text { o Probe Wall } \\
\text { o Probe Wall, Control }\end{array}$ & $\begin{array}{l}522-922 \text { F } \\
145-715 \mathrm{~F} \\
\text { Yes }\end{array}$ \\
\hline Thermal Boundary Condition & Constant wall Temperature \\
\hline Maximum Sampling Period & $114 \mathrm{hr}$ \\
\hline $\begin{array}{l}\text { Gas-Side: } \\
0 \text { Velocity } \\
0 \text { Turbulence Intensity } \\
0 \text { Fouling Factor }\end{array}$ & $\begin{array}{l}43-450 \mathrm{ft} / \mathrm{sec} \\
-- \\
\text { Yes }\end{array}$ \\
\hline $\begin{array}{l}\text { Gas R.hararterization } \\
0 \text { Fuel Analysis } \\
0 \text { Gaseous Components } \\
0 \text { Dew-Point Temperatures } \\
0 \text { Particle Size Distribution } \\
\text { o Partirle rnmposition } \\
0 \text { Particle Concentration } \\
0 \text { Excess Air } \\
0 \text { Measurement Techniques } \\
\end{array}$ & $\begin{array}{lc}\text { Yes } & \vdots: \\
-- & \vdots \\
-- & \vdots \\
-- & \vdots \\
\text { Yer } & \vdots \\
\text { Yes! } & \vdots \\
X \text { XRF, EPA Method 5, FS } \\
\end{array}$ \\
\hline $\begin{array}{l}\text { Deposit Characterization } \\
\text { o Constituents } \\
\text { o Deposit Morphology } \\
\text { o Deposit Melting Temperature } \\
\text { o Corrosion Analysis } \\
\text { o Deposit Mass } \\
\text { o Measurement Techniques }\end{array}$ & $\begin{array}{l}\text { Yes } \\
\text { Yes } \\
-- \\
-- \\
45-225 \mathrm{~g} \\
\text { XRF }\end{array}$ \\
\hline
\end{tabular}


Table 4-7. Gas-Side Fouling Probe Survey Matrix:

Institute for Thermal Engineering and Energy Research, Vinca, Yugoslavia

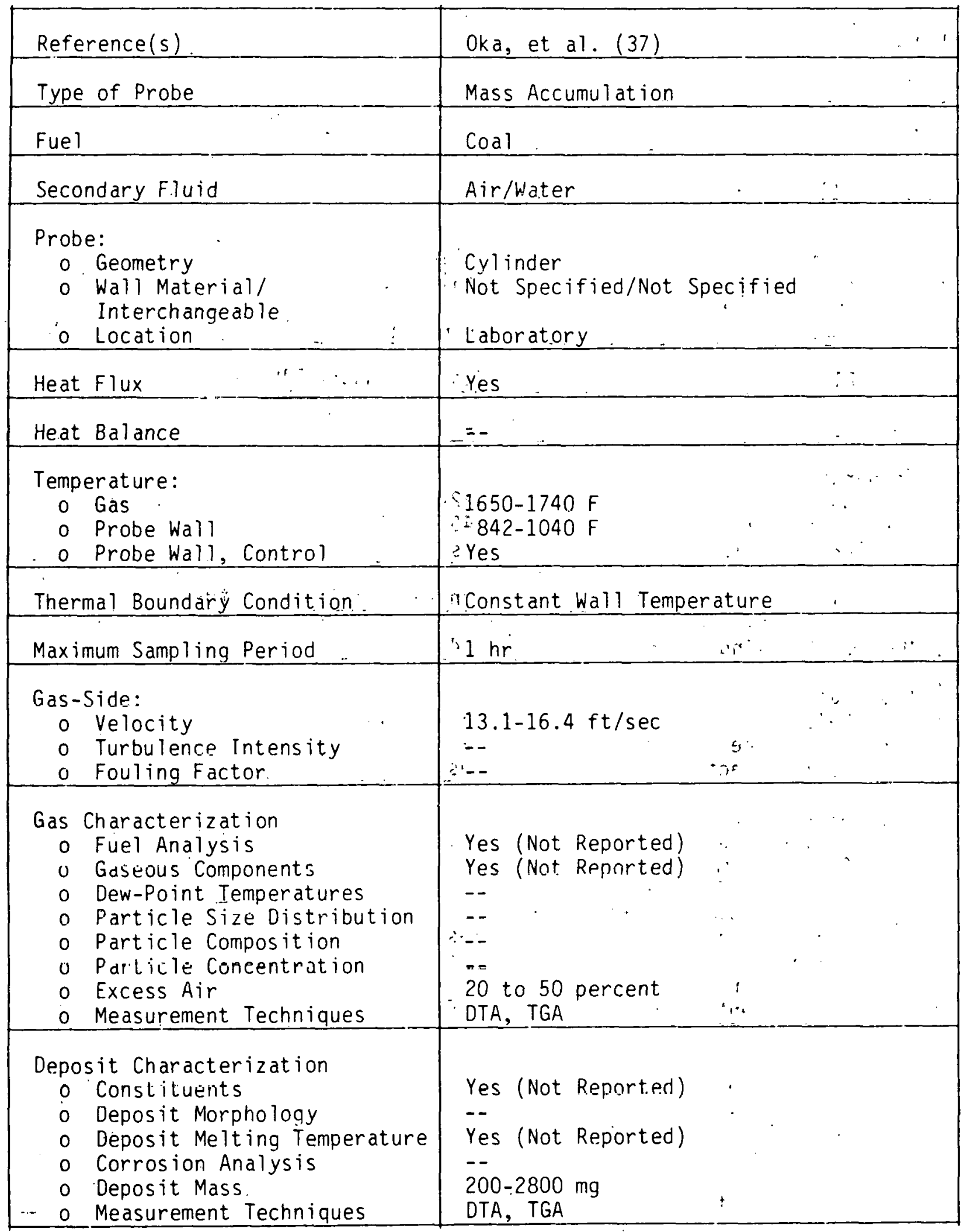


Table 4-8. Gas-Side Fouling Probe Survey Matrix:

Exxon Research and Engineering Company, Baytown, Texas

\begin{tabular}{|c|c|c|}
\hline Reference (s) & Lin and Winegartner (38) & \\
\hline Type of Probe & Mass Accumulation & \\
\hline Fuel & Coal & \\
\hline Secondary Fluid & Air & \\
\hline $\begin{array}{l}\text { Probe: } \\
\text { o Geometry } \\
\text { o Wall Material/ } \\
\text { Interchangeable } \\
\text { o Location } \\
\end{array}$ & $\begin{array}{l}\text { Cylinder: } d=0.75 \text { in. } \\
304 \text { Stainless Steel } / \text { No } \\
\text { Solid Fuel Evaluation Unit }\end{array}$ & \\
\hline Heat Flux & -- & \\
\hline Heat Balance & - & \\
\hline $\begin{array}{l}\text { Temperature: } \\
\text { o Gas } \\
\text { o Probe Wall } \\
\text { o Probe Wall, Control }\end{array}$ & $\begin{array}{l}1300-2000 \mathrm{~F} \\
800-1200 \mathrm{~F} \\
\text { Yes }\end{array}$ & " \\
\hline Thermal Boundary Condition & Constant Wal1 Temperature & \\
\hline Máximum Sampling Period & Not Specified & \\
\hline $\begin{array}{l}\text { Gas-Side: } \\
\text { o Velocity } \\
0 \text { Turbulence Intensity } \\
0 \text { Fouling Fartinr }\end{array}$ & $\begin{array}{l}15 \mathrm{ft} / \mathrm{sec} \\
-- \\
--\end{array}$ & \\
\hline $\begin{array}{l}\text { Gas Characterization } \\
0 \text { Fuel Analysis } \\
0 \text { Gaseous Components } \\
0 \text { Dew-Point Temperatures } \\
0 \text { Particle Size Distribution } \\
0 \text { Particle Composition } \\
0 \text { Particle Concentration } \\
0 \text { Excess Air } \\
0 \text { Measurement Techniques } \\
\end{array}$ & $\begin{array}{l}\text { Yes } \\
\text { Yes } \\
-- \\
-- \\
\text { Yes } \\
--1 \\
\sim 16 \text { percent } \\
\text { Not Sperified }\end{array}$ & 2 \\
\hline $\begin{array}{l}\text { Deposit Characterization } \\
0 \text { Constituents } \\
0 \text { Deposit Morphology } \\
0 \text { Deposit Melting Temperature } \\
0 \text { Corrosion Analysis } \\
0 \text { Deposit Mass } \\
0 \text { Measurement Techniques }\end{array}$ & $\begin{array}{l}\text { Yes } \\
\text { Yes } \\
-- \\
\text { Up to } 5.0 \mathrm{~g} \\
\text { Not Specified }\end{array}$ & \\
\hline
\end{tabular}


Table 4-9. Gas-Side Fouling Probe Survey Matrix:

Central Electricity Generating Board, United Kingdom

\begin{tabular}{|c|c|}
\hline Reference (s) & Jackson and Raask $(39-40)$ \\
\hline Type of Probe & Mass ficcumulation \\
\hline Fuel & Coal, Residual 0il \\
\hline Secondary Fluid & Air \\
\hline $\begin{array}{l}\text { Probe: } \\
0 \text { Geometry } \\
0 \text { Wall Material/ } \\
\text { Interchangeable } \\
\text { o. Location } \\
\end{array}$ & $\begin{array}{l}\text { Cylinder: } d=1.00 \mathrm{in.}, L=6 \text { to } 13 \mathrm{ft} \\
\text { Austenitic Steel/No } \\
\text { Boiler }\end{array}$ \\
\hline Heat Flux & -- \\
\hline Heat Balance & - \\
\hline $\begin{array}{l}\text { Temperature: } \\
\text { o Gas } \\
\text { o Probe Wall } \\
\text { o Probe Wall, Control }\end{array}$ & $\begin{array}{l}950-2100 \mathrm{~F} \\
150-1800 \mathrm{~F} \\
\text { Yes }\end{array}$ \\
\hline Thermal Boundäry Condition & "Constant Wall Temperature (Locally) \\
\hline Maximum Sampling Period & $350 \mathrm{hr}$ \\
\hline $\begin{array}{l}\text { Gas-Side: } \\
0 \text { Velocity } \\
0 \text { Turbulence Intensity } \\
0 \text { Fouling Factor } \\
\end{array}$ & $\begin{array}{ll}3.5-10.2 \mathrm{ft} / \mathrm{sec} & \mathrm{s} \\
-- & \because \\
--\end{array}$ \\
\hline $\begin{array}{l}\text { Gas Characterization } \\
0 \text { Fuel Analysis } \\
\text { 0 Gaseous Components } \\
\text { 0 Dew-Point Temperatures } \\
0 \text { Particle Size Distribution } \\
0 \text { Particle Composition } \\
\text { o Particle Concentraliur } \\
0 \text { Excess Air } \\
0 \text { Measurement Techniques } \\
\end{array}$ & $\begin{array}{l}-- \\
\text { Partial } \\
-- \\
-- \\
-- \\
0.5 \text { to } 3.0 \text { percent } \\
--\end{array}$ \\
\hline $\begin{array}{l}\text { Deposit Characterization } \\
0 \text { Constituents } \\
0 \text { Deposit Morphology } \\
0 \text { Deposit Melting Temperature } \\
0 \text { Corrosion Analysis } \\
0 \text { Deposit Mass } \\
0 \text { Measurement Techniques } \\
\end{array}$ & $\begin{array}{l}\text { Yes } \\
\text { Yes } \\
\text { Yes (Separate Probe for Corrosion) } \\
\text { Yes (Mass Deposition Rate Reported) } \\
\text { CA, AA, GA, FP }\end{array}$ \\
\hline
\end{tabular}


Table 4-10. Gas-Side Fouling Probe Survey Matrix:

Central Electricity Research Laboratories, Leatherhead, Surrey, United Kingdom

\begin{tabular}{|c|c|}
\hline Reference (s) & Dalmon, et al. (41) \\
\hline Type of Probe $\quad \therefore \quad . \quad$ & Mass Accumulation \\
\hline Fuel & $0 i 1$ \\
\hline Secondary Fluid & Air \\
\hline $\begin{array}{l}\text { Probe: } \\
\text { o Geometry } \\
\text { o Wall Material }: \\
\text { Interchangeable } \\
\text { o loration }\end{array}$ & $\begin{array}{l}\text { Thin Disc: } D=5.32 \text { in. } \\
\text { Gold Plated Brass/Yes } \\
\text { Boiler }\end{array}$ \\
\hline Heat Flux & $\ldots$ \\
\hline Heat Balance & -- \\
\hline $\begin{array}{l}\text { Temperature: } \\
\text { o Gas } \\
0 \text { Probe Wall } \\
0 \text { Probe Wall, Control }\end{array}$ & $\begin{array}{l}293^{\prime} \mathrm{F} \\
158-320 \mathrm{~F} \\
\text { Yes }\end{array}$ \\
\hline Thermal Boundary Condition & Constant Wall Temperature \\
\hline Maximum Sampling Period & $24 \mathrm{hr}$ \\
\hline $\begin{array}{l}\text { Gas-Side: } \\
\text { o Velocity } \\
\text { o Turbulence Intensity } \\
0 \text { Fouling Factor } \\
\end{array}$ & $\begin{array}{l}\cdots- \\
\cdots- \\
-- \\
\end{array}$ \\
\hline $\begin{array}{l}\text { Gas Characterization } \\
0 \text { Fuel Analysis } \\
0 \text { Gaseous Components } \\
0 \text { Dew-Point Temperatures } \\
0 \text { Partiçle Size Distribution } \\
0 \text { Particle Composition } \\
0 \text { Particle Concentration } \\
\text { 0 Excess Air } \\
0 \text { Measurement Techniques } \\
\end{array}$ & $\begin{array}{l} \\
- \\
\text { Partial } \\
\text { Predicted } \\
-- \\
\text { Yes! } \\
--: \\
-- \\
\text { Not Specified }\end{array}$ \\
\hline $\begin{array}{l}\text { Deposit Characterization } \\
0 \text { Constituents } \\
0 \text { Deposit Morphology } \\
0 \text { Deposit Melting Temperature } \\
0 \text { Corrosion Analysis } \\
0 \text { Deposit Mass } \\
0 \text { Measurement Techniques }\end{array}$ & $\begin{array}{l}\text { Yes } \\
-- \\
=- \\
\text { No Corrosion } \\
\text { Yes (Mass Deposition Rate Reported) } \\
\text { CA }\end{array}$ \\
\hline
\end{tabular}


Table 4-11. Gas-Side Fouling Probe Survey Matrix:

National Engineering Laboratory, East Kilbride, Glasgow, Scotland

\begin{tabular}{|c|c|}
\hline Reference (s) & Isdale, et al. (42-43) \\
\hline Type of Probe & Mass Accumulation \\
\hline Fuel & Diesel, Municipal Waste \\
\hline Secondary Fluid & Air/Water \\
\hline $\begin{array}{l}\text { Probe: } \\
\text { o Geometry } \\
\text { o Wall Material/ } \\
\text { Interchangeable } \\
\text { o Location } \\
\end{array}$ & $\begin{array}{l}: \text { Axially Split Cylinder: } d=1.0 \text { in." } \\
316 \text { SS, Copper, Mild Steel/Yes } \therefore \\
\text { Diesel Engine, Municipal Incinerator }\end{array}$ \\
\hline Heat Flux & Yes (Secondary Fluid) \\
\hline Heat Balance & $\ldots$ \\
\hline $\begin{array}{l}\text { Temperature: } \\
\text { o Gas } \\
\text { o Probe Wall } \\
\text { o Probe Wall, Control }\end{array}$ & 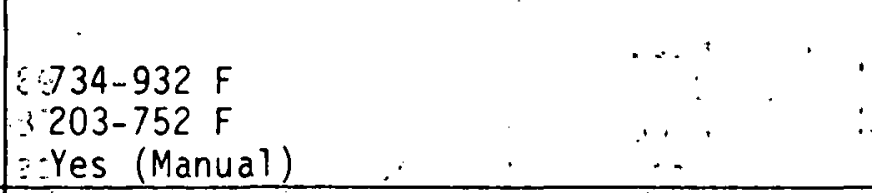 \\
\hline Thermal Boundary Condition: & $\because$ Constant Wali Temperature (Locally) \\
\hline Maximum Sampling Period & $38.5 \mathrm{hr}$ \\
\hline $\begin{array}{l}\text { Gas-Side: } \\
\text { o Velocity } \\
\text { o Turbulence Intensity } \\
\text { o Fouling Factor }\end{array}$ & $\begin{array}{l}39-67 \mathrm{ft} / \mathrm{sec} . \\
-- \\
--\end{array}$ \\
\hline $\begin{array}{l}\text { Gas Characterization } \\
\text { 0 Fuel Analysis } \\
\text { o Gaseous Cuminunents } \\
\text { o Dew-Point Temperatures } \\
\text { o Particle Size Distribution } \\
\text { o Particle Composition } \\
\text { o Parlicle Curicentration } \\
\text { o Excess Air } \\
\text { o Measurement Techniques }\end{array}$ & 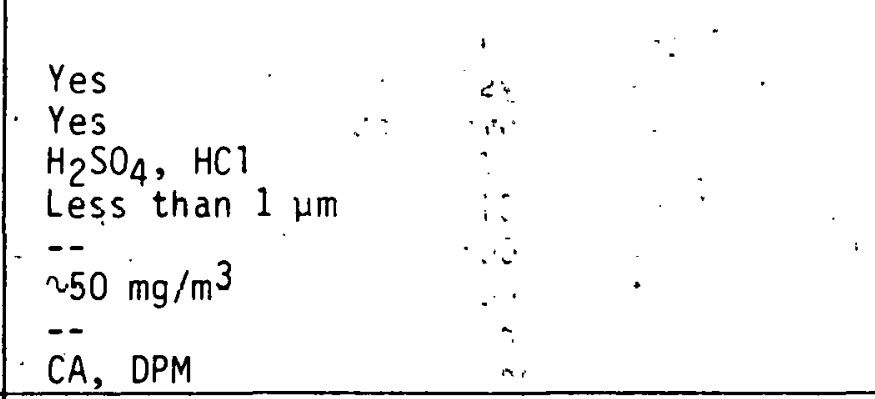 \\
\hline $\begin{array}{l}\text { Deposit Characterization } \\
0 \text { Constituents } \\
\text { o Deposit Morphology } \\
0 \text { Deposit Melting Temperature } \\
0 \text { Corrosion Analysis } \\
\text {. Deposit Mass } \\
0 \text { Measurement Techniques }\end{array}$ & $\begin{array}{l}\text { Yes } \\
\text { Yes } \\
-- \\
-- \\
4-708 \mathrm{mg} \\
\text { GLC, HPLGPC }\end{array}$ \\
\hline
\end{tabular}


Table 4-12. Gas-Side Fouling Probe Survey Matrix: Central Electricity Generating Board, United Kingdom

\begin{tabular}{|c|c|}
\hline Reference (s) & Holland, et al. (44) \\
\hline Type of Probe & Mass Accumulation \\
\hline Fuel & $0 i 1$ \\
\hline Secondary Fluid & Steam \\
\hline $\begin{array}{l}\text { Probe: } \\
0 \text { Geometry } \\
0 \text { Wall Material/ } \\
\text { Interchangeable } \\
0 \quad \text { Location } \\
\end{array}$ & $\begin{array}{l}\text { Multiple Hair Pin Cylinders: } d=0.75 \text { in. } \\
\text { AISI } 347,321,316,420 / \text { Yes } \\
\text { Boiler }\end{array}$ \\
\hline Heat Flux & -- \\
\hline Heat Bal ance & $\ldots$. \\
\hline $\begin{array}{l}\text { Temperature: } \\
\text { o Gas } \\
\text { o Probe Wall } \\
\text { o Probe Wall, Control }\end{array}$ & $\begin{array}{r}1940-2084 \mathrm{~F} \\
250-1260 \mathrm{~F} \\
\text { Yes: }\end{array}$ \\
\hline Thermal Boundary Condition & Constant Wall Temperature (Locally) $\therefore$ \\
\hline Maximum Sampling Period & $2000^{\circ} \mathrm{hr}$ \\
\hline $\begin{array}{l}\text { Gas-Side: } \\
0 \text { Velocity } \\
0 \text { Turbulence Intensity } \\
0 \quad \text { Fouling Factor } \\
\end{array}$ & $\begin{array}{l}22-24 \mathrm{ft} / \mathrm{ser} \\
-- \\
--\end{array}$ \\
\hline $\begin{array}{l}\text { Gas Characterization } \\
0 \text { Fuel Analysis } \\
0 \text { Gaseous Components } \\
0 \text { Dew-Point Temperatures } \\
0 \text { Particle Size Distribution } \\
0 \text { Particle Composition } \\
0 \text { Particle Concentration } \\
0 \text { Excess Air } \\
0 \text { Measurement Techniques } \\
\end{array}$ & $\begin{array}{l}\text { Yes } \\
\text { Yes } \\
-- \\
= \\
\text { Yes } \\
-- \\
\sim 2.5 \text { percent } \\
\text { PI, CT, CA }\end{array}$ \\
\hline $\begin{array}{l}\text { Deposit Characterization } \\
\text { o Constituents } \\
0 \text { Deposit Morphology } \\
0 \text { Deposit Melting Temperature } \\
0 \text { Corrosion Analysis } \\
0 \text { Deposit Mass } \\
0 \text { Measurement Techniques } \\
\end{array}$ & $\begin{array}{l}\text { Yes } \\
\text { Yes } \\
\text { Yes } \\
\text { Yes (Mass Deposition Rate Reported) } \\
\text { EM, XRD, CA }\end{array}$ \\
\hline
\end{tabular}


Table 4-13. Gas-Side Fouling Probe Survey Matrix: NASA-Lewis Research Center, Cleveland, Ohio

\begin{tabular}{|c|c|}
\hline Reference (s) & Kohl, et al. (45) \\
\hline Type of Probe & Mass Accumulation \\
\hline Fuel & Doped Jet A-1 \\
\hline Secondary Fluid & -- \\
\hline $\begin{array}{l}\text { Probe: } \\
0 \text { Geometry } \\
\text { o Wall Material/ } \\
\text { Interchangeable } \\
\text { - Location } \\
\end{array}$ & $\begin{array}{l}\text { Rotating Cylinder: } d=L=0.50 \mathrm{in} . \\
10 \% \mathrm{Rh}-90 \% \mathrm{Pt} / \text { Yes } \\
\text { Experimental Mach } 0.3 \mathrm{Rig}\end{array}$ \\
\hline Heat Flux & $\begin{array}{ll}- \\
--\end{array}$ \\
\hline Heat Balance & $-{ }_{1}+\cdots$ \\
\hline $\begin{array}{l}\text { Temperature: } \\
\text { o Gas } \\
\text { o Probe Wall } \\
\text { o Probe Wall, Control }\end{array}$ & $\begin{array}{l}2520-2780 \mathrm{~F} \\
1250-1880 \mathrm{~F} \\
\text { Yes }\end{array}$ \\
\hline Thermal Boundary Condition & Constant Wall Temperature \\
\hline Maximum Sampling Period & $12 \mathrm{hr}$ \\
\hline $\begin{array}{l}\text { Gas-Side: } \\
\text { o Velocity } \\
\text { o Turbulence Intensity } \\
\text { o Fouling Factor }\end{array}$ & $\begin{array}{l}\text { Yes (Not Reported) } \\
\text { Estimated } \\
=\end{array}$ \\
\hline $\begin{array}{l}\text { Gas Characterization } \\
\text { o Fuel Analysis } \\
0 \text { Gascous Components } \\
0 \text { Dew-Point Temperatures } \\
0 \text { Particle Size Distribution } \\
0 \text { Particle Composition } \\
0 \text { Particle Concentration } \\
0 \text { Excess Air } \\
0 \text { Measurement Techniques } \\
\end{array}$ & $\begin{array}{l}-- \\
\text { Partial } \\
\text { Predicted } \\
\mathrm{Na}_{2} \mathrm{SO}_{4}, \mathrm{CaSO}_{4} \\
-- \\
-- \\
-- \\
\text { Yes (Fuel-to-Air Ratio) } \\
\mathrm{BC}\end{array}$ \\
\hline $\begin{array}{l}\text { Deposit Characterization } \\
0 \text { Constituents } \\
0 \text { Deposit Morphology } \\
\text { o Deposit Melting Temperature } \\
0 \text { Corrosion Analysis } \\
0 \text { Deposit Mass } \\
0 \text { Measurement Techniques } \\
\end{array}$ & $\begin{array}{l}\text { Yes } \\
\text { Yes } \\
-- \\
\text { Yes } \\
2-18 \mathrm{mg} \\
\text { EDS, XRD, XRF }\end{array}$ \\
\hline
\end{tabular}


Table 4-14. Gas-Side Fouling Probe Survey Matrix: Solar Turbines International, San Diego, California

\begin{tabular}{|c|c|}
\hline Reference (s) & White (46) \\
\hline - Type of Probe & Mass Accumulation \\
\hline Fuel & $J P-5$ \\
\hline Secondary-Fluid & Water \\
\hline $\begin{array}{l}\text { Probe: } \\
\text { o Geometry } \\
\text { o Wall Material/ } \\
\text { Interchangeable } \\
\text { o Location }\end{array}$ & $\begin{array}{l}\text { Cylinder: } d=0.5 \text { in., } L=8 \text { in. } \\
\text { Hastelloy } x / \text { No } \\
\text { Experimental Combustion Rig }\end{array}$ \\
\hline Heat Filux & $\ldots \ldots$ \\
\hline Heat Balance & $\therefore \because$ \\
\hline $\begin{array}{l}\text { Temperature: } \\
\text { o Gas } \\
\text { o Probe Wall } \\
0 \text { Probe Wall, Control }\end{array}$ & $\begin{array}{l}17,42 \mathrm{~F} \\
172:-230 \mathrm{~F} \\
\text { Yes }\end{array}$ \\
\hline Thermal Boundary'Condition $\therefore:$ & Cónstant wall Temperaturè (Locally) $\therefore \therefore$ \\
\hline Maximum Sampling. Pẹriod & Not Reported \\
\hline $\begin{array}{l}\text { Gas-Side: } \\
\text { o Velocity } \\
\text { o Turbulence Intensity } \\
\text { o Fouling Factor }\end{array}$ & Mas's Flowrate. \\
\hline $\begin{array}{l}\text { Gas Characterization } \\
\text { o Fuel Analysis } \\
\text { o Gaseous Components } \\
\text { o Dew-Point Temperatures } \\
\text { o Particle Size Distribution } \\
\text { o Particle Composition. } \\
\text { o Particle Concentration } \\
\text { o Excess Air } \\
\text { o Measurement Techniques } \\
\end{array}$ & 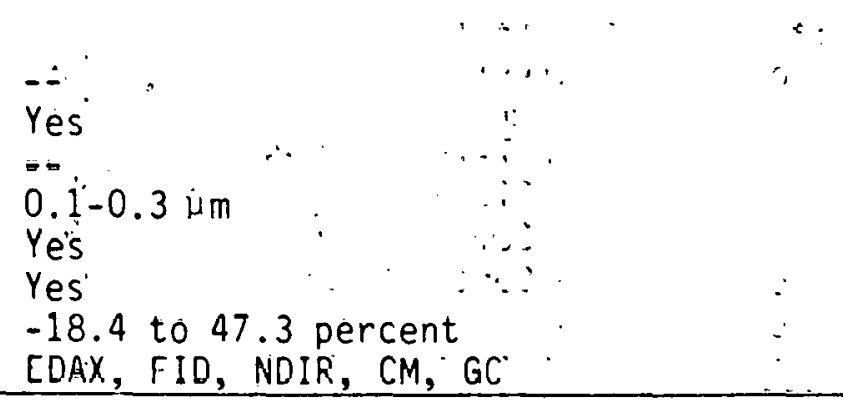 \\
\hline $\begin{array}{l}\text { Deposit Characterization } \\
\text { o Constituents } \\
\text { o Deposit Morphology } \\
0 \text { Deposit Melting Temperature } \\
0 \text { Corrosion Analysis } \\
0 \text { Deposit Mass } \\
0 \text { Measurement Techniques }\end{array}$ & $\begin{array}{l}\text { Yes } \\
\text { Yes } \\
\cdots \\
\text { Yes (Mass Deposition Rate Reported) } \\
\text { CA, SEM, IR, EDAX, GC. }\end{array}$ \\
\hline
\end{tabular}


Table 4-15: Gas-Side Fouling Probe Survey Matrix: Central Electricity Generating. Board, United Kingdom

\begin{tabular}{|c|c|}
\hline Reference (s) & Horn and Street $(47-49)$ \\
\hline Type of Probe & Mass Accumulation \\
\hline Fuel & Coal, $0 i 1$ \\
\hline Secondary Fluid & Air \\
\hline $\begin{array}{l}\text { Probe: } \\
0 \text { Geometry } \\
\text { o Wall Material/ } \\
\text { Interchangeable } \\
\text { o Location }\end{array}$ & 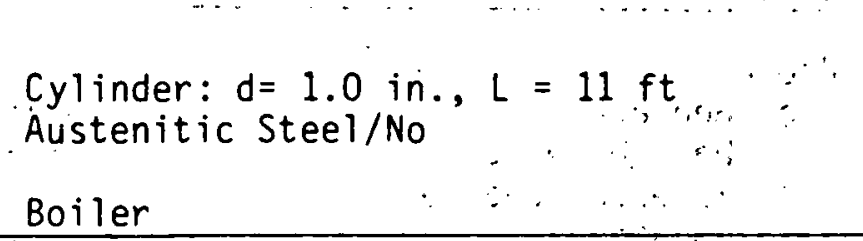 \\
\hline Heat Flux & $\begin{array}{llll}\because & \ddots & \cdots & \cdots \cdots \\
- & & & \ldots \\
\end{array}$ \\
\hline Heat Balance & $\begin{array}{lll}\cdots & \cdots \\
\cdots & \cdots \\
\end{array}$ \\
\hline $\begin{array}{l}\text { Temperature: } \\
\text { o Gas. } \\
0 \text { Probe Wall } \\
0 \text { Probe Wall, Control }\end{array}$ & $\begin{array}{l}1652-2372 \mathrm{~F} \\
1004-1652 \mathrm{~F} \\
\text { Yes }\end{array}$ \\
\hline Thermal Boundary. Condition. & Constant Wall Temperature (Locally) \\
\hline Maximum Sampling Period & $20 \mathrm{hr}: \cdots \cdots$ \\
\hline $\begin{array}{l}\text { Gas-Side: } \\
0 \text { Velocity } \\
0 \text { Turbulence Intensity } \\
0 \text { Fouling Factor }\end{array}$ & $\begin{array}{l}10-45: \mathrm{ft} / \mathrm{sec} \\
- \\
-\end{array}$ \\
\hline $\begin{array}{l}\text { Gas Characterization } \\
\text { 0 Fuel Analysis } \\
\text { 0 Gaseous Components } \\
\text { o Dew-Point Temperatures } \\
\text { 0 Particle Size Distribution } \\
\text { 0 Particle Composition } \\
0 \text { Particle Concentration } \\
\text { 0 Excess Air } \\
\text { 0 Measurement Techniques }\end{array}$ & 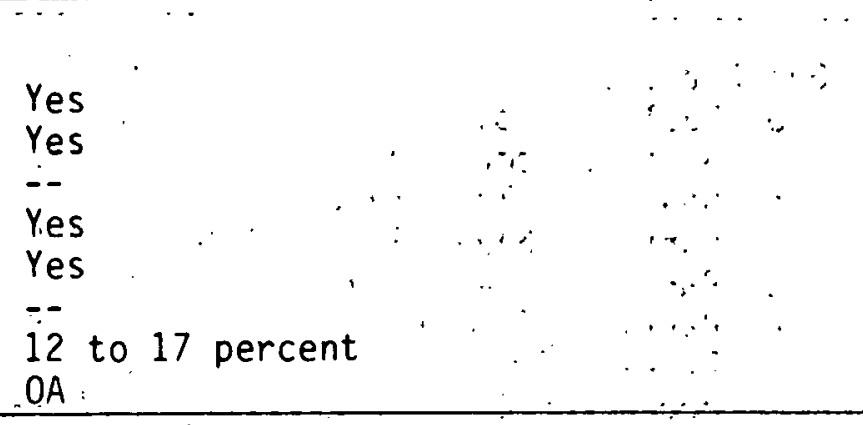 \\
\hline $\begin{array}{l}\text { Deposit Characterization } \\
0 \text { Constituents } \\
0 \text { Deposit Morphology } \\
0 \text { Deposit Melting Temperature } \\
0 \text { Corrosion Analysis } \\
0 \text { Deposit Mass } \\
0 \text { Measurement Techniques }\end{array}$ & $\begin{array}{l}\text { Yes } \\
\text { Yes }\end{array}$ \\
\hline
\end{tabular}


Table 4-16. Gas-Side. Fouling Probe Survey Matrix:

Grand Forks Energy Research Center, Grand Forks, North Dakota

\begin{tabular}{|c|c|}
\hline Reference $(\mathrm{s})$ & Tufte, et al. (50-53) \\
\hline Type of Probe & Mass Accumulation \\
\hline Fuel & Coal \\
\hline Secondary Fluid & Air \\
\hline $\begin{array}{l}\text { Probe: } \\
\text { o Geometry } \\
0 \text { Wall Material/ } \\
\text { Interchangeable } \\
\text { o Location }\end{array}$ & $\begin{array}{l}\text { Multiple Cylinders: } d=1.66 \text { in. } \\
304 \cdot \text { Stainless Steel/No } \\
\text { GFERC Laboratory }\end{array}$ \\
\hline Heat Flux & -- \\
\hline Heat Balance & - \\
\hline $\begin{array}{l}\text { Temperature: } \\
0 \text { Gas- } \\
0 \text { Probe Wall } \\
0 \text { Probe Wall, Control }\end{array}$ & 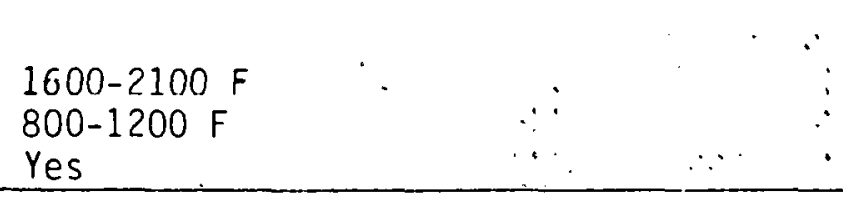 \\
\hline Thermal Boundary Conditions & Constant wall Temperature: (Locally) $\therefore \because$ \\
\hline Maximum Sampling Period & $8 \mathrm{hr}$ \\
\hline $\begin{array}{l}\text { Gas-Side: } \\
0 \text { Velocity } \\
0 \text { Turbulence Intensity } \\
0 \text { Fouling Factor } \\
\end{array}$ & $\begin{array}{c}25 \mathrm{ft} / \mathrm{sec} \text { (Maximum value between tubes) } \\
\because \\
--\end{array}$ \\
\hline $\begin{array}{l}\text { Gas Characterization } \\
\text { o Fuel Analysis } \\
\text { o Gaseous Components } \\
\text { o Dew-Point Temperatures } \\
\text { o Particle Size Distribution } \\
\text { o Particle Composition } \\
0 \text { Particle Concentration } \\
0 \text { Excess Air } \\
\text { o Measurement Techniques } \\
\end{array}$ & $\begin{array}{l}\text { Yes: } \\
-- \\
-- \\
-- \\
\text { Yes: } \\
-- \\
5 \text { to } 50 \text { percent } \\
\text { CA, EM, FSS, XRO }\end{array}$ \\
\hline $\begin{array}{l}\text { Deposit Characterization } \\
\text { o Constituents } \\
\text { o Deposit Morphology } \\
\text { o Deposit Melting Temperature } \\
\text { o Corrosion Analysis } \\
\text { o Deposit Mass } \\
0 \text { Measurement Techniques }\end{array}$ & $\begin{array}{l}\text { Yes } \\
\text { Yes } \\
\text { Yes } \\
-- \\
\text { Up to } 1800 \text { g } \\
\text { CA, EM, XRD, XRF. }\end{array}$ \\
\hline
\end{tabular}


Table 4-17. Gas-Side Fouling Probe Survey Matrix:

Westinghouse Research and Development Center, Pittsburgh, Pennsylvania

\begin{tabular}{|c|c|}
\hline Reference (s) & Whitlow, et al. (54-57) \\
\hline Type of Probe & Mass Accumulation \\
\hline Fue? & Simulated, Actual Residual 0il; SRC-II \\
\hline Secondary Fluid & Air \\
\hline $\begin{array}{l}\text { Probe: } \\
0 \text { Geometry } \\
0 \text { Wall Material/ } \\
\text { Interchangeable } \\
\text { o Location }\end{array}$ & $\begin{array}{l}\text { Multiple Cylinders: } d=0.5-1.0 \text { in. } \\
\text { Many/Yes } \\
\text { Westinghouse R\&D Center Test Pas.sage }\end{array}$ \\
\hline Heat Flux & - \\
\hline Hẹạt Bạlance & -- \\
\hline $\begin{array}{l}\text { Temperature: } \\
0 \text { Gas } \\
0 \text { Probe Wall } \\
\text { o. Probe Wall, Control }\end{array}$ & $\begin{array}{r}1650-2300 \mathrm{~F}^{\cdots} \\
931-1710 \mathrm{~F} \\
\text { Yes }\end{array}$ \\
\hline Thermart. Boundary Condition : - & Constant:Wall Temperature. (Locally). $\because$ \\
\hline Maximum Sampling Period & $300 \mathrm{hr}$ \\
\hline $\begin{array}{l}\text { Gas-Side: } \\
0 \text { Velocity } \\
0 \text { Turbulence Intensity } \\
0 \text { Fouling Factor }\end{array}$ & $\begin{array}{l}2600 \mathrm{ft} / \mathrm{sec} \\
-- \\
--\end{array}$ \\
\hline $\begin{array}{l}\text { Gas Characterization } \\
0 \text { Fuel Analysis } \\
0 \text { Gaseous Components } \\
0 \text { Dew-Point Temperatures } \\
\text { o Particle Size Distribution } \\
0 \text { Particle Composition } \\
0 \text { Particle Concentration } \\
0 \text { Excess Air } \\
0 \text { Measurement Techniques } \\
\end{array}$ & $\begin{array}{l}\text { Yes } \\
-- \\
-- \\
0.1-1.5 \mathrm{Hm} \\
\text { Yes } \\
-- \\
-- \\
\text { ISP, XRD, ES, AA, SEM, EDAX, EM }\end{array}$ \\
\hline $\begin{array}{l}\text { Deposit Characterization } \\
\text { o Constituents } \\
0 \text { Deposit Morphology } \\
0 \text { Deposit Melting Temperature } \\
\text { o Corrosion Analysis } \\
0 \text { Deposit Mass } \\
0 \text { Measurement Techniques }\end{array}$ & $\begin{array}{l}\text { Yes } \\
\text { Yes } \\
-- \\
\text { Yes } \\
0.02-12.22 \text { g } \\
\text { XRD, SEM, EDAX, CA, IR, EM }\end{array}$ \\
\hline
\end{tabular}


Table 4-18. Gas-Side Fouling Probe Survey Matrix:

Department of Physical Sciences, The Polytechnic, Wolverhampton, United Kinadom

\begin{tabular}{|c|c|}
\hline 'Reference(s) & Bishop and Cliffe (58) \\
\hline :Type of Probe & Mass Accumulation \\
\hline Fuel $\quad \because \cdots$ & Propane Doped with $\mathrm{NaCl}$ \\
\hline - Secondary Fluid & Air \\
\hline $\begin{array}{l}\text { Probe: } \\
\text { o Geometry } \\
\text { o Wall Material/ } \\
\text { Interchangeable } \\
\text { o Location }\end{array}$ & $\begin{array}{l}\text { Cylinder: } d=2.0 \text { in., } L=1.0 \mathrm{in.} \\
12 \% \text { chromium steel coated with } \\
\text { borosilicate enamel/Yes } \\
\text { Laboratory Combustor }\end{array}$ \\
\hline Heat Flux & 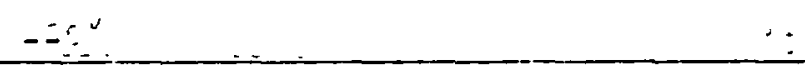 \\
\hline : Heat Balance & $\therefore \because$ \\
\hline $\begin{array}{l}: \text { Temperature: } \\
\quad \begin{array}{l}\text { o Gas } \\
0\end{array} \\
0 \text { Probe Wall } \\
0 \text { Probe Wall, Control... }\end{array}$ & $\begin{array}{l}2012 F \\
1022=1472 F \\
\text { Yes }\end{array}$ \\
\hline Thermal- Boundary Condition $\cdots$ & Cönstant Wall Temperature \\
\hline Maximum Sampling Period... & 15 min \\
\hline $\begin{array}{l}\text { Gas-Side: } \\
\text { o Velocity } \\
\text { o Turbulence Intensity } \\
\text { o Fouling Factor }\end{array}$ & 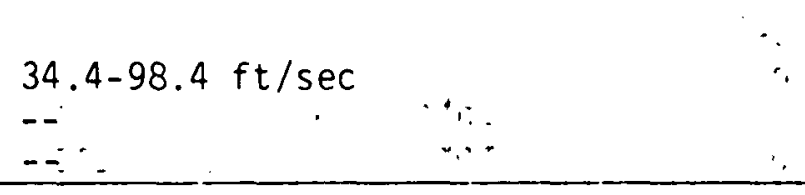 \\
\hline $\begin{array}{l}\text { Cas Characterization } \\
0 \text { Fuel Analysis } \\
0 \text { Gaseous Componerits } \\
0 \text { Dew-Point Temperatures } \\
0 \text { Particle Size Distribution } \\
0 \text { Particle Composition } \\
0 \text { Particle Concentration } \\
0 \text { Excess Air } \\
0 \text { Measurement Techniques }\end{array}$ & $\begin{array}{l}\overline{0} ; \mathrm{CO}, \mathrm{NaCl} \\
\mathrm{NaCl} \\
-- \\
- \\
- \\
- \\
\text { Not Specified }\end{array}$ \\
\hline $\begin{array}{l}\text { Deposit Characterization } \\
\text { o Constituents } \\
\text { o Deposit Morphology } \\
\text { o Meposit Melting Temperature } \\
\text { o Corrosion Analysis } \\
\text { o Deposit Mass } \\
0 \text {. Measurement Techniques } \\
\end{array}$ & $\begin{array}{l}\text { NaCi } \\
\text { Yes } \\
\text { Yes } \\
\text { No Corrosion Present. } \\
\text { Yes (Mass Deposition Rate Reported): } \\
\text { SEM }\end{array}$ \\
\hline
\end{tabular}


Table 4-19. Gas-Side Fouling Probe Survey Matrix:

Yale University, New Haven, Connecticut

\begin{tabular}{|c|c|}
\hline Reference (s) & Rosner, et al. (59-61) \\
\hline Type of Probe & Optical \\
\hline Fuel & $\mathrm{C}_{3} \mathrm{H}_{8}$ seeded with several compounds \\
\hline Secondary Fluid & Not Applicable \\
\hline $\begin{array}{l}\text { Probe: } \\
\text { o Geometry } \\
\text { o Wall Material/ } \\
\text { Interchangeable } \\
\text { o Location }\end{array}$ & $\begin{array}{c}\text { Thin Ribbon: } 0.005 \times 0.24 \times 3.74 \mathrm{in} . \\
\text { Platinum/Yes } \\
\text { Laboratory }\end{array}$ \\
\hline Heat Flux & Yes \\
\hline Heat Balance & $\cdots$ \\
\hline $\begin{array}{l}\text { Temperature: } \\
\text { o Gas } \\
\text { o Probe Wail } \\
\text { o Probe Wall, Control }\end{array}$ & $\begin{array}{l}\text { Not Specified } \\
1628-1880 \mathrm{~F} \\
\text { Yes }\end{array}$ \\
\hline Thermal Boundary E,ondition & Constant Heat Flux \\
\hline Maximum Sampling Period & $3 \mathrm{~min}$ \\
\hline $\begin{array}{l}\text { Gas-Side: } \\
\text { o Velocity } \\
\text { o Turbulence Intensity } \\
0 \text { Fouling Factor }\end{array}$ & $\begin{array}{ll} & \\
-- & \vdots \\
-- & \vdots \\
- & - \\
\end{array}$ \\
\hline $\begin{array}{l}\text { Gas Characterization } \\
0 \text { Fuel Analysis } \\
0 \text { Gaseous Components } \\
0 \text { Dew-Point Temperatures } \\
0 \text { Particle Size Distribution } \\
0 \text { Particle Composition } \\
0 \text { Particle Concentration } \\
0 \text { Excess Air } \\
0 \text { Measurement Techniques } \\
\end{array}$ & \begin{tabular}{lcc} 
& & $\ddots$ \\
Yes & & $\cdots$ \\
$\mathrm{B}_{2} \mathrm{O}_{3}, \mathrm{Na}_{2} \mathrm{SU}_{4}, \mathrm{Cs}_{2} \mathrm{SU}_{4}$, & $\mathrm{K}_{2} \mathrm{SO}_{4}$ & $\cdots$ \\
$2.5 \mu \mathrm{m}$ & $\cdots$ & $\cdots$ \\
Yes & $\cdots$ & $\ddots$ \\
Yes & $\ddots$ & $\ddots$ \\
\hdashline
\end{tabular} \\
\hline $\begin{array}{l}\text { Deposit Characterization } \\
0 \text { Constituents } \\
0 \text { Deposit Morphology } \\
0 \text { Deposit Melting Temperature } \\
0 \text { Corrosion Analysis } \\
0 \text { Deposit Mass: } \\
0 \text { Measurement Techniques }\end{array}$ & $\begin{array}{lc}\text { Yes } & \because \\
-- & \because \\
\text { Yes } & \vdots \\
-- & \vdots \\
\text { Yes (Mass Deposition Rate Reported) } \\
\text { XPS }\end{array}$ \\
\hline
\end{tabular}


Table 4-20. Gas-Side Fouling Probe Survey Matrix:

University of Toronto, Toronto, Ontario, Canada

\begin{tabular}{|c|c|}
\hline Reference (s) & Reeve, Tran, and Barham $(62-64)$ \\
\hline Type of Probe & Deposition \\
\hline Fuel & Black Liquor \\
\hline Secondary Fluid & Air \\
\hline $\begin{array}{l}\text { Probe: } \\
\text { o Geometry } \\
0 \text { Wall Material/ } \\
\text { Interchangeable } \\
\text { o Location }\end{array}$ & $\begin{array}{l}\text { Cylinder } \\
\text { Not specified/No } \\
\text { Furnace, Superheater }\end{array}$ \\
\hline Heat Flux & -- \\
\hline Heat Balance & - \\
\hline $\begin{array}{l}\text { Temperature: } \\
\text { o Gas } \\
\text { o Probe Wall } \\
\text { o Probe Wall, Control }\end{array}$ & $\begin{array}{l}950-1460 \mathrm{~F} \\
430-1070 \mathrm{~F} \\
\text { Yes }\end{array}$ \\
\hline Thermal. Boundar.y Condition & Constant Wall. Temperature (Locally). \\
\hline Maximum Sampling Period & $900 \mathrm{hr}$ \\
\hline $\begin{array}{l}\text { Gas-Side: } \\
\text { o Velocity } \\
\text { o Turbulence Intensity } \\
\text { o Fouling Factor } \\
\end{array}$ & $\begin{array}{l}-- \\
- \\
-\end{array}$ \\
\hline $\begin{array}{l}\text { Gas Characterization. } \\
0 \text { Fuel Analysis } \\
0 \text { Gaseous Components } \\
0 \text { Dew-Point Temperatures } \\
0 \text { Particle Size Distribution } \\
0 \text { Particle Composition } \\
0 \text { Partical Soncentration } \\
0 \text { Exccss Air } \\
0 \text { Measurement Techniques }\end{array}$ & $\begin{array}{l}\text { Partial } \\
-\overline{-} \\
\overline{-} \\
\text { Partial } \\
-- \\
\overline{-} \\
\text { Not Specifind }\end{array}$ \\
\hline $\begin{array}{l}\text { Deposit Characterization } \\
\text { o Constituents } \\
\text { o Deposit Morphology } \\
\text { o Deposit Melting Temperature } \\
\text { o Corrosion Analysis } \\
\text { o Deposit Mass } \\
\text { o Measurement Techniques }\end{array}$ & $\begin{array}{l}\text { Yes } \\
\text { Yes } \\
\text { Yes } \\
-- \\
-\overline{S E M}, \text { CS, DTA, NA, AA }\end{array}$ \\
\hline
\end{tabular}


Table 4-21. Gas-Side-Fouling Probe Survey Matrix:

Bureau of Mines, U.S. Department of the Interior, Washington, D.C.

\begin{tabular}{|c|c|}
\hline Reference $(\mathrm{s})$ & Barkley, et al. (65) \\
\hline Type of Probe & Deposition \\
\hline Fuel & Coal \\
\hline Secondary Fluid & Water or Steam \\
\hline $\begin{array}{l}\text { Probe: } \\
\text { o Geometry } \\
\text { o Wall Material/ } \\
\text { Interchangeable } \\
\text { o Location } \\
\end{array}$ & $\begin{array}{l}\text { Cylinder: } d=1.5 \text { in., } L=76 \text { in. } \\
\text { Steel/No } \\
\text { Naval Gur. Factor Boiler }\end{array}$ \\
\hline Heat Flux & $\ldots$ \\
\hline Heat Balance & $\therefore \quad !$ \\
\hline $\begin{array}{l}\text { Temperature: } \\
\text { o Gas } \\
\text { o Probe Wall } \\
\text { o. Probe Wall, Control }\end{array}$ & 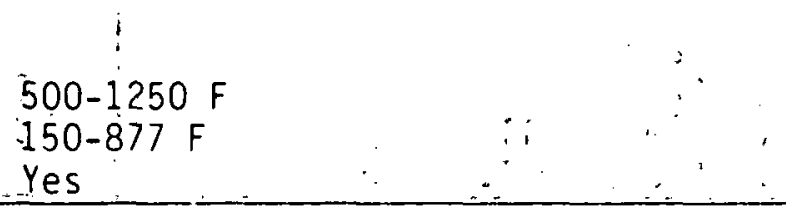 \\
\hline Thermal Boundary Condition 2 & Constant Wall Temperature (Locally) \\
\hline Maximum Sampling Period & $313 \mathrm{hr}$ \\
\hline $\begin{array}{l}\text { Gas-Side: } \\
0 \text { Velocity } \\
0 \text { Turbulence Intensity } \\
0 \text { Fouling Factor }\end{array}$ & $\begin{array}{l}-- \\
-- \\
= \\
\end{array}$ \\
\hline $\begin{array}{l}\text { Gas Characterization } \\
\text { o Fuel Analysis } \\
0 \text { Gaseous Components } \\
0 \text { Dew-Point Temperatures } \\
\text { o Particle Size Distribution } \\
0 \text { Particle Composition } \\
0 \text { Particle Concentraliun } \\
0 \text { Excess Air } \\
0 \text { Measurement Techniques }\end{array}$ & $\begin{array}{l}\text { Yes } \\
\text { Partial } \\
\mathrm{H}_{2} \mathrm{SO}_{4} \\
\text { Yes } \\
\text { Yes } \\
-- \\
-- \\
\mathrm{CA}\end{array}$ \\
\hline $\begin{array}{l}\text { Deposit Characterization } \\
\text { o Constituents } \\
\text { 0 Deposit Morphology } \\
0 \text { Deposit Melting Temperature } \\
\text { o Corrosion Analysis } \\
\text { 0 Deposit Mass } \\
0 \text { Measurement Techniques }\end{array}$ & $\begin{array}{l}\text { Yes } \\
\text { Yes } \\
-- \\
-- \\
-- \\
\text { CA }\end{array}$ \\
\hline
\end{tabular}


Table 4-22. Gas-Side Fouling Probe Survey Matrix:

CSIRO Division of Process Technology, North Ryde, Australia

\begin{tabular}{|c|c|}
\hline Reference (s) & Durie, et al. (66) \\
\hline Type of Probe & Deposition \\
\hline Fuel & Propane $(86 \%)$ doped with $\mathrm{SO}_{2}$ and $\mathrm{Na}$ \\
\hline Secondary Fluid & Air \\
\hline $\begin{array}{l}\text { Probe: } \\
\text { o Geometry } \\
0 \text { Wall Material/ } \\
\text { Interchangeable } \\
\text { o Location. }\end{array}$ & $\begin{array}{l}\text { Cylinder: } d=0.6 \text { in., } L=3.94 \mathrm{in} . \\
\text { Stainless Steel/Yes } \\
\text { Burner and Probe Laboratory Assembly }\end{array}$ \\
\hline Heat Flux & -- \\
\hline Heat Balance & - \\
\hline $\begin{array}{l}\text { Temperature: } \\
0 \text { Gas } \\
\text { o Probe Wall } \\
0 \text { Probe Wall, Control }\end{array}$ & $\begin{array}{l}2960-3680 \mathrm{~F} \\
841 \mathrm{~F} \\
\text { Yes }\end{array}$ \\
\hline Thermal Boundary Condition & Constant Wall Temperature (Locall.y.). \\
\hline Maximum Sampling Period & $25 \min$ \\
\hline $\begin{array}{l}\text { Gas-Side: } \\
\text { o Velocity } \\
0 \text { Turbulence Intensity } \\
0 \text { Fouling Factor }\end{array}$ & $\begin{array}{l}3.9-4.6 \mathrm{ft} / \mathrm{sec} \\
-\therefore \\
--\end{array}$ \\
\hline $\begin{array}{l}\text { Gas Characterization } \\
0 \text { Fuel Analysis } \\
0 \text { Gaseous Components } \\
0 \text { Dew-Point Temperatures } \\
0 \text { Particle Size Distribution - } \\
0 \text { Particle Composition } \\
0 \text { Particle Concentration } \\
0 \text { Excess Air } \\
0 \text { Measurement Techniques } \\
\end{array}$ & $\begin{array}{l}\text { Yes } \\
\text { Yes } \\
-- \\
\text { Yes } \\
-\overline{-} \\
\text { Not to } 110 \text { perified. }\end{array}$ \\
\hline $\begin{array}{l}\text { Deposit Characterization } \\
\text { o Constituents } \\
0 \text { Deposit Morphology } \\
0 \text { Deposit Melting Temperature } \\
\text { o Corrosion Analysis } \\
0 \text { Deposit Mass } \\
0 \text { Measurement Techniques } \\
\end{array}$ & $\begin{array}{l}\text { Yes } \\
-- \\
-- \\
-- \\
\sim 0.05 \mathrm{gg} \\
\mathrm{CA}, \mathrm{IR}\end{array}$ \\
\hline
\end{tabular}


Table 4-23. Gas-Side Fouling Probe Survey Matrix:

University of Tennessee Space Institute, Tullahoma, Tennessee

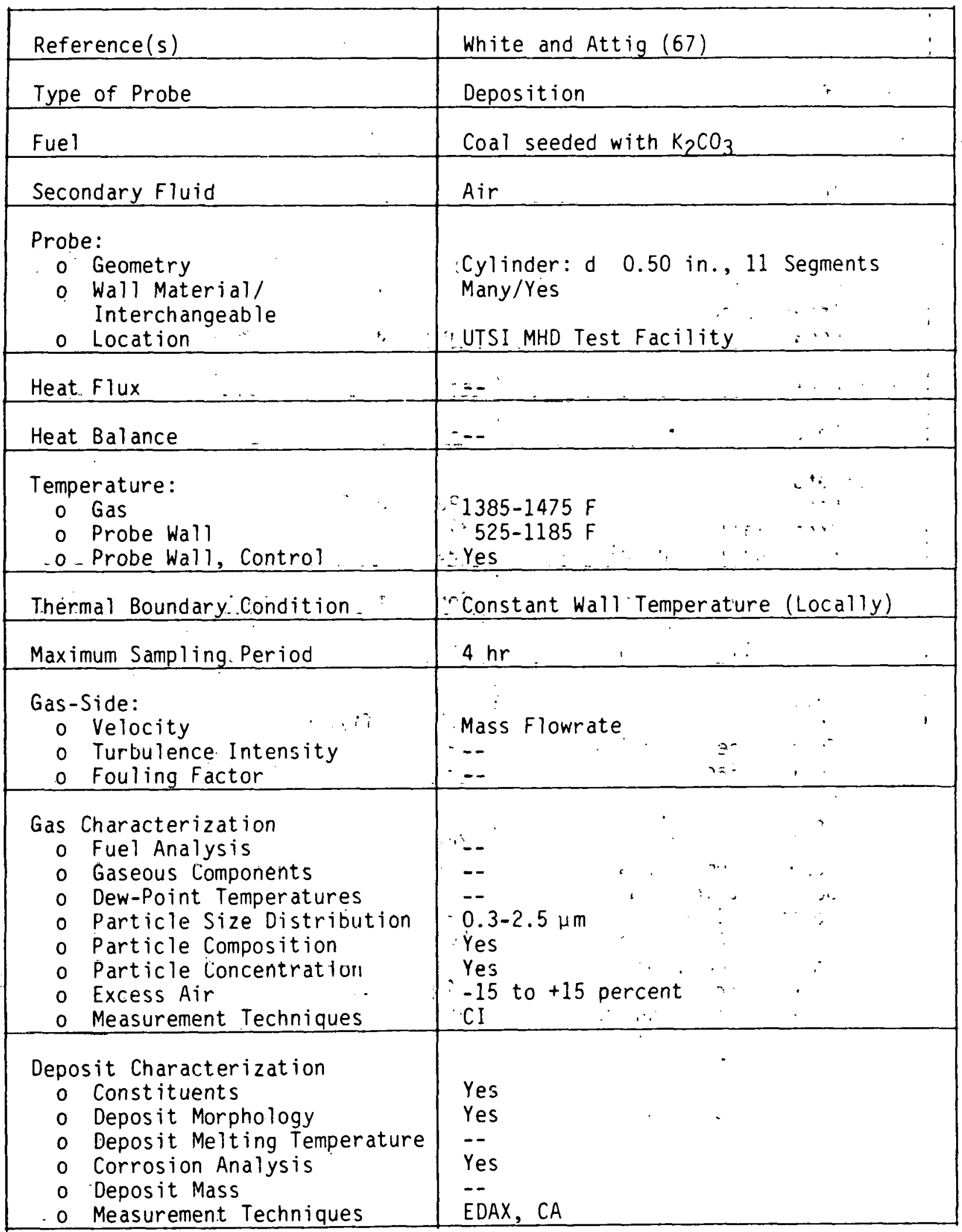


Table 4-24. Gas-Side Fouling Probe Survey Matrix:

Battelle Columbus Laboratories, Columbus, Ohio

\begin{tabular}{|c|c|}
\hline Reference (s) & Krause, et al. $(68-76)$ \\
\hline Type of Probe & Deposition \\
\hline Fuel & Solid Waste, Refuse, Coal, Sludge \\
\hline Secondary Fluid & Water/Air \\
\hline $\begin{array}{l}\text { Probe: } \\
\text { o Geometry } \\
\text { o Wall Material/ } \\
\text { Interchangeable } \\
\text { o Location }\end{array}$ & $\begin{array}{l}\text { Cylinder: } d=1.0 \text { in., } 18-34 \text { Segments } \\
\text { Many/Yes } \\
\text { Incinerator; Electric Plant, Laboratory }\end{array}$ \\
\hline Heat Flux & - \\
\hline Heat Balance & -- \\
\hline $\begin{array}{l}\text { Temperature: } \\
\text { o Gos } \\
0 \text { Probe Wall } \\
0 \text { Probe Wall, Control }\end{array}$ & $\begin{array}{l}1100-1700 \mathrm{~F} \\
250-1250 \mathrm{~F} \\
\text { Yes }\end{array}$ \\
\hline Thermal Boundary Condition & Constant Wall Temperature (Locally). \\
\hline Max imum Sampling Period & \\
\hline $\begin{array}{l}\text { Gas-Side: } \\
0 \text { Velocity } \\
0 \text { Turbulence Intensity } \\
0 \text { Fouling Factor } \\
\end{array}$ & $\begin{array}{l}0.2-0.5 \mathrm{ft} / \mathrm{sec} \\
-- \\
--\end{array}$ \\
\hline $\begin{array}{l}\text { Gas Characterization } \\
\text { o Fuel Analysis } \\
\text { o Gaseous Components } \\
\text { n Dew-Point Temperatures } \\
\text { o Particle Size Distribution } \\
\text { o Particle Composition } \\
\text { o Particle Concentration } \\
\text { o Excess Air } \\
\text { n Measurement Techniqurs }\end{array}$ & $\begin{array}{l}\text { Yes } \\
\text { Yes } \\
-- \\
-- \\
\text { Yes } \\
-- \\
25 \text { to } 350 \text { percent } \\
\text { OES, XRD, MS, CA, OA, SDA }\end{array}$ \\
\hline $\begin{array}{l}\text { Deposit Characterization } \\
\text { o Constituents } \\
\text { o Deposit Morphology } \\
\text { o Deposit Mclting Temperature } \\
\text { o Corrosion Analysis } \\
\text { o Deposit Mass } \\
\text { o Measurement Techniques } \\
\end{array}$ & $\begin{array}{l}\text { Yes } \\
\text { Yes } \\
-- \\
\text { Yes } \\
-\bar{O} \\
\text { OES, CA; XRD, OM, EM, EDAX, MS, EPA ST }\end{array}$ \\
\hline
\end{tabular}


Table 4-25. Gas-Side Fouling Probe Survey Matrix: Combustion Engineering, Inc., Windsor, Connecticut

\begin{tabular}{|c|c|}
\hline Reference $(\mathrm{s})$ & Plumiey, et al. (77-78) \\
\hline Type of Probe & Deposition \\
\hline Fuel & Coal. \\
\hline Secondary. Fluid & Water/Air \\
\hline $\begin{array}{l}\text { Probe: } \\
\text { o Geometry } \\
0 \text { Wall Material/ } \\
\text { Interchangeable } \\
\text { o Location }\end{array}$ & $\begin{array}{l}\text { Cylinder: Up to } 28 \text { Segments } \\
\text { Many/Yes } \\
\text { Laboratory, Boiler }\end{array}$ \\
\hline Heat. Flux & $\therefore$ \\
\hline Heat Balance & - \\
\hline $\begin{array}{l}\text { Temperature: } \\
\text { o Gas } \\
\text { o Probe Wall } \\
\text { o. Probe Wall, Control }\end{array}$ & $\begin{array}{r}1100-2260 \mathrm{~F} \\
995-1900 \mathrm{~F} \\
\text { Yes }\end{array}$ \\
\hline Thérmal Boundary Condition: & Constant Wall Temperature (Locally) \\
\hline Maximum Sampling Period & 8081 hr \\
\hline $\begin{array}{l}\text { Gas-Side: } \\
0 \text { Velocity } \\
0 \text { Turbulence Intensity } \\
0 \text { Fouling Factor } \\
\end{array}$ & $\begin{array}{l}56.8-63.8 \mathrm{ft} / \mathrm{sec} \\
-- \\
-- \\
\end{array}$ \\
\hline $\begin{array}{l}\text { Gas Characterization } \\
0 \text { Fuel Analysis } \\
0 \text { Gaseous Components } \\
\text { 0 Dew-Point Temperatures } \\
0 \text { Particle Size Distribution } \\
0 \text { Particle Composition } \\
\text { o Particle Concentration } \\
0 \text { Excess Air } \\
\text { o Measurement Techniques } \\
\end{array}$ & $\begin{array}{l}\text { Yes } \\
-- \\
-- \\
-- \\
-- \\
-- \\
-- \\
\text { Not Specified. }\end{array}$ \\
\hline $\begin{array}{l}\text { Deposit Characterization } \\
0 \text { Constituents } \\
0 \text { Deposit Morphology } \\
0 \text { Deposit Melting Temperature } \\
0 \text { Corrosion Analysis } \\
0 \text { Deposit Mass } \\
\therefore .0 \text { Measurement Techniques }\end{array}$ & $\begin{array}{l}\text { Yes } \\
\text { Yes } \\
\text { Yes } \\
\text { Yes } \\
-- \\
\text { EM, XRD, XRF, CA }\end{array}$ \\
\hline
\end{tabular}


Table 4-26. Gas-Side Fouling Probe Survey Matrix:

Electric Energy, Inc., Joppa, 111 inois

\begin{tabular}{|c|c|}
\hline Reference (s) & Koopman, et al. (79) \\
\hline Type of Probe & Deposition \\
\hline Fuel & Coal \\
\hline Secondary Fluid & Air/water \\
\hline $\begin{array}{l}\text { Probe: } \\
0 \text { Geometry } \\
\text { o Wall Material/ } \\
\text { Interchangeable } \\
\text { o Location }\end{array}$ & $\begin{array}{l}\text { Cylinder: } d=2.0 \text { in., Attached Segments } \\
\text { T-11, T-22, } 321 \text { SS/Yes } \\
\text { Boiler }\end{array}$ \\
\hline Heat Flux $\quad \cdots \quad \ldots$ & - \\
\hline Heat Balance & $r=$ \\
\hline $\begin{array}{l}\text { Temperature: } \\
\text { o Gas } \\
0 \text { Probe Wall } \\
\text { o Probe Wall, Control. }\end{array}$ & $\begin{array}{l}\text { il } 1800 \mathrm{~F} \\
850-1350 \mathrm{~F} \\
\text { Yes }\end{array}$ \\
\hline Thermal Boundary Conditions. & Constant wall Temperature (Localiyy). \\
\hline Maximum Sampling Period & $1000 \mathrm{hr}$ \\
\hline $\begin{array}{l}\text { Gas-Side: } \\
0 \text { Velocity } \\
0 \text { Turbulence Intensity } \\
0 \text { Fouling Factor }\end{array}$ & $\begin{array}{l}- \\
-- \\
--\end{array}$ \\
\hline $\begin{array}{l}\text { Gas Characterization } \\
0 \text { Fuel Analysis } \\
\text { o Gaseous Components } \\
\text { o Dew-Point Temperatures } \\
0 \text { Particle Size Distribution } \\
0 \text { Particle Composition } \\
\text { o Particle Concentration } \\
\text { o Excess Air } \\
0 \text { Measurement Techniques } \\
\end{array}$ & $\begin{array}{l}\text { Yes } \\
-- \\
-- \\
-- \\
-- \\
-- \\
-- \\
\text { Not Specifled }\end{array}$ \\
\hline $\begin{array}{c}\text { Deposit Characterization } \\
0 \text { Constituents } \\
0 \text { Deposit Morphology } \\
0 \text { Deposit Melting Temperature } \\
0 \text { Corrosion Analysis } \\
0 \text { Deposit Mass } \\
0 \text { Measurement Techniques }\end{array}$ & $\begin{array}{l}\text { Yes } \\
\text { Yes } \\
\text { Yes } \\
\text { Yes } \\
-- \\
\text { Not Specified }\end{array}$ \\
\hline
\end{tabular}


Table 4-27. Gas-Side Fouling Probe Survey Matrix:

Battelle Memorial Institute, Columbus, Ohio

\begin{tabular}{|c|c|}
\hline Reference (s) & Krause, et al. (80) \\
\hline Type of Probe & Deposition \\
\hline Fue & Residual 0 il \\
\hline Secondary Fluid & Air \\
\hline $\begin{array}{l}\text { Probe: } \\
\text { o. Geometry } \\
\text { o Wall Material/ } \\
\text { Interchangeable } \\
\text { - Location }\end{array}$ & $\begin{array}{l}\text { Multiple Cylinders: } d=1.0 \text { in. } L=2.0 \text { in: } \\
T-11, T-22,347 \text { SS, Inconel } 600 / Y \text { es } \\
\text { Laboratory Scale Combustor } \cdots, A\end{array}$ \\
\hline Heat Flux & $\begin{array}{lllll}\cdots & \cdots & \cdots & \end{array}$ \\
\hline Heat Balance & $\begin{array}{lll}- & \\
\end{array}$ \\
\hline $\begin{array}{l}\text { Temperature: } \\
0 \text { Gas } \\
0 \text { Probe Wall } \\
0 \text { Probe Wall, Control }\end{array}$ & $\begin{array}{lll}1673-1947 \mathrm{~F} & & \therefore ; \\
1100 \mathrm{~F} & & \therefore i\end{array}$ \\
\hline Thermal Boundary. Condition & Constant Wall Temperature \\
\hline Maximum Sampling Period & $\begin{array}{lll}50 h r & \\
\end{array}$ \\
\hline $\begin{array}{l}\text { Gas-Side: } \\
0 \text { Velocity } \\
0 \text { Turbulence Intensity } \\
0 \text { Fouling Factor }\end{array}$ & $\begin{array}{ll}22.7 \mathrm{ft} / \mathrm{sec} & \\
-\therefore & \\
\end{array}$ \\
\hline $\begin{array}{l}\text { Gas Characterization } \\
\text { o Fuel Analysis } \\
\text { o Gaseous Components } \\
\text { 0 Dew-Point Temperatures } \\
0 \text { Particle Size Distribution } \\
\text { o Particle Composition } \\
\text { o Particle Concentration } \\
\text { o Excess Air } \\
\text { o Measurement Techniques }\end{array}$ & 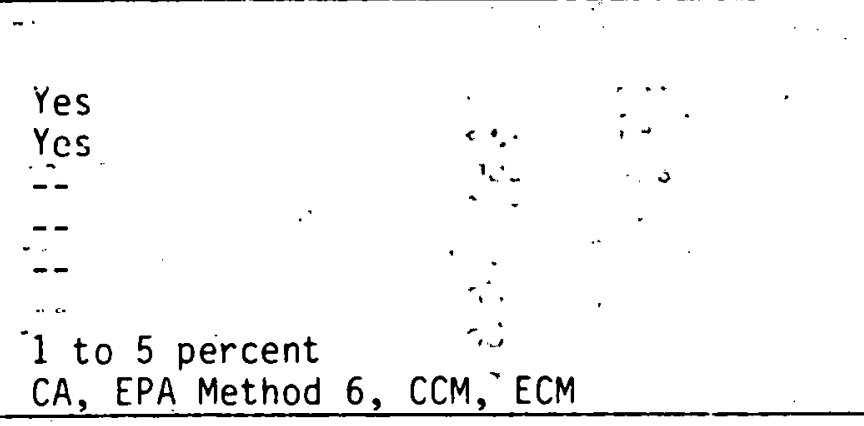 \\
\hline $\begin{array}{l}\text { Deposit Characterization } \\
\text { o Coristituents } \\
0 \text { Deposit Morphology } \\
0 \text { Deposit Melting Temperature } \\
0 \text { Corrosion Analysis } \\
0 \text { Deposit Mass } \\
0 \text { Measurement Techniques }\end{array}$ & $\begin{array}{l}\text { Yes } \\
\overline{\text { Yes }} \\
-- \\
\text { Special Apparatus for Deposit Strength }\end{array}$ \\
\hline
\end{tabular}


Table 4-28. Gas-Side Fouling Probe Survey Matrix:

Solar Turbines Incorporated, San Diego, California

\begin{tabular}{|c|c|}
\hline Reference(s) & Russe11, et al. (81) \\
\hline Type of Probe & Deposition \\
\hline Fuel & No. 6 Fuel $0 i l$, Natural Gas \\
\hline Secondary Fluid & Air \\
\hline $\begin{array}{l}\text { Probe: } \\
\text { o Geometry } \\
\text { o Wall Material/ } \\
\text { Interchangeable } \\
\text { o Location } \\
\end{array}$ & $\begin{array}{l}\text { Multiple Cylinders, Multiple Sections } \\
\text { Six Stainless Steels, Seven Superalloys, } \\
\text { Eight Ceramics/Yes } \\
\text { Alumlnum Melting Furnace }\end{array}$ \\
\hline Heat Flux &.-- \\
\hline Heat Balance & -- \\
\hline $\begin{array}{l}\text { Temperature: } \\
0 \text { Gas } \\
0 \text { Probe Wall } \\
0 \text { Probe Wall, Control }\end{array}$ & $\begin{array}{l}2000-2100 \mathrm{~F} \\
1200-2100 \mathrm{~F} \\
\text { Yes }\end{array}$ \\
\hline Thermal Boundary Condition . & Constant Wall Température (Locally). \\
\hline Maximum Sampling Period & $24 \dot{48} \mathrm{hr}$ \\
\hline $\begin{array}{l}\text { Gas-Side: } \\
0 \text { Velocity } \\
0 \text { Turbulence Intensity } \\
0 \text { Fouling Factor } \\
\end{array}$ & $\begin{array}{l}-- \\
-- \\
--\end{array}$ \\
\hline $\begin{array}{l}\text { Gas Characterization } \\
0 \text { Fuel Analysis } \\
0 \text { Gaseous Components } \\
0 \text { Dew-Point Temperatures } \\
0 \text { Particle Size Distribution } \\
0 \text { Particle Composition } \\
0 \text { Particle Concentration } \\
0 \text { Excess Air } \\
0 \text { Measurement Techniques } \\
\end{array}$ & $\begin{array}{l}\text { Yes } \\
\text { Yes } \\
=- \\
\text { Yes } \\
-\overline{-} \\
\text { No percent } \\
\text { Not Specified }\end{array}$ \\
\hline $\begin{array}{l}\text { Deposit Characterization } \\
0 \text { Constituents } \\
0 \text { Deposit Morphology } \\
0 \text { Deposit Melting Temperature } \\
0 \text { Corrosion Analysis } \\
0 \text { Deposit Mass } \\
0 \text { Measurement Techniques } \\
\end{array}$ & 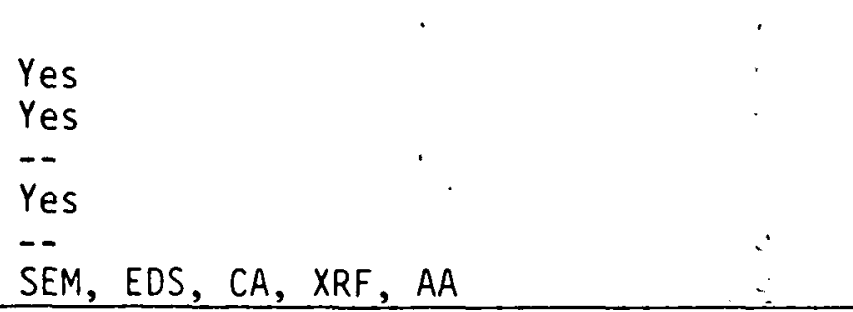 \\
\hline
\end{tabular}


Table 4-29. Gas-Side Fouling Probe Survey Matrix:

Central Electricity Research Laboratories, United Kingdom

\begin{tabular}{|c|c|}
\hline Reference (s) & Alexander, et al. (82) \\
\hline Type of Probe & Acid Condensation \\
\hline Fuel & Fuel 0 il \\
\hline Secondary Fluid & Air \\
\hline $\begin{array}{l}\text { Probe: } \\
\text { o Geometry } \\
0 . \text { Wall Material/ } \\
\text { Interchangeable } \\
\text { o Location }\end{array}$ & $\begin{array}{l}\text { Cylinder: } d=1.00 \text { in. } L=8 \mathrm{ft} \\
\text { Austenitic Stainless Steel/No } \\
\text { Boiler }\end{array}$ \\
\hline Heat Fiux & - \\
\hline Heat Balance & $\because$ \\
\hline $\begin{array}{l}\text { Temperature: } \\
\quad \text { Gas } \\
0 \text { Probe Wall } \\
\text { o Probe Wall, Control }\end{array}$ & \begin{tabular}{lll} 
& & $\therefore$ \\
\hdashline $175-332 F$ & & $\therefore$ \\
Yes & $\therefore$ & $\therefore$ \\
\end{tabular} \\
\hline Thermal Boundary Condition.: & Constant Wall Temperature (Locally) \\
\hline Maximum Sampling Period & $2 h r$ \\
\hline $\begin{array}{l}\text { Gas-Side: } \\
0 \text { Velocity } \\
0 \text { Turbulence Intensity } \\
0 \text { Fouling Factor } \\
\end{array}$ & 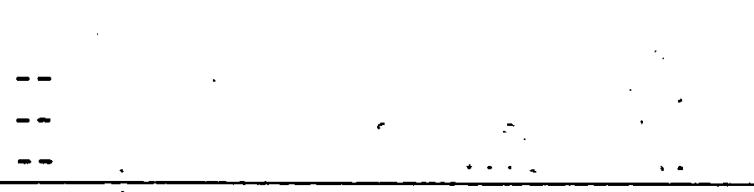 \\
\hline $\begin{array}{l}\text { Gas Characterization } \\
0 \text { Fuel Analysis } \\
0 \text { Gascous Components } \\
0 \text { Dew-Point Temperatures } \\
0 \text { Particle Size Distribution } \\
0 \text { Particle Composition } \\
0 \text { Particle Concontration } \\
0 \text { Excess Air } \\
0 \text { Measurement Techniques } \\
\end{array}$ & $\begin{array}{cc} & \ddots \\
\vdots & \ddots \\
\vdots & \\
\vdots & \\
\vdots & \\
\vdots & \\
\end{array}$ \\
\hline $\begin{array}{l}\text { Deposit Characterization } \\
0 \text { Constituents } \\
0 \text { Deposit Morphology } \\
0 \text { Deposit Melting Temperature } \\
0 \text { Corrosion Analysis } \\
0 \text { Deposit Mass } \\
0 \text { Measurement Techniques }\end{array}$ & $\begin{array}{l}\text { Yes } \\
\text { Yes } \\
-- \\
-- \\
18.6-358.2 \mathrm{mg} \\
\text { CA }\end{array}$ \\
\hline
\end{tabular}


Table 4-30. Gas-Side Fouling Probe Survey Matrix:

She 11 Research, Limited, Thornton Research Centre, Chester, United Kingdom

\begin{tabular}{|c|c|}
\hline Reference (s) & Ross (83) \\
\hline Type of -Probe & Acid Condensation \\
\hline -Fuel $\cdots$ & Propane-Air-Sulfur Dioxide \\
\hline Secondary Fluid & Boiling Coolant \\
\hline $\begin{array}{l}\text { Probe: } \\
0 \text { Geometry } \\
0 \text { Wall Material/ } \\
\text { Interchangeable } \quad \therefore \quad \\
\text { o Location }\end{array}$ & $\begin{array}{l}\text { Cyilinder: } d=0.669 \text { in., } L=2.00 \text { in. } \\
\text { Gold-Plated Copper } / \text { No. } \\
\text { Laboratory Combustion R1g }\end{array}$ \\
\hline - Heat Flux & $\ldots$ \\
\hline Heat Balance & $\therefore$ \\
\hline $\begin{array}{l}\text { Temperature: } \\
\quad \text { Gas } \\
0 \text { Probe Wall } \\
\text {. } 0 \text { Probe Wal } 1 ; \text { Control...... }\end{array}$ & 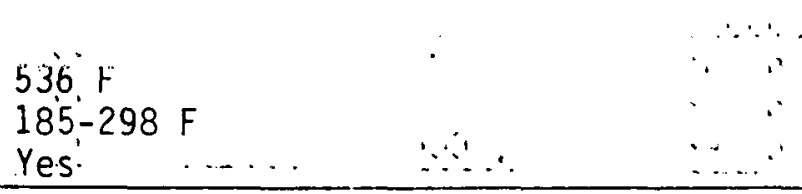 \\
\hline Thermal Boundary' Condition ' & Constant Wall Tempèràture \\
\hline Maximum Sampling Period $\because \because \because$ & $20^{\prime} \min \ldots$ \\
\hline $\begin{array}{l}\text { Gas-Side: } \\
\text { o Velocity } \\
0 \text { Turbulence Intensity } \\
0 \text { Fouling Factor }\end{array}$ & $\begin{array}{r}16 \mathrm{ft} / \mathrm{sec} \\
-\therefore \\
-\therefore \\
\end{array}$ \\
\hline $\begin{array}{l}\text { Gas Characterization } \\
\text { o Fuel Analysis } \\
0 \text { Gaseous Components } \\
0 \text { Dew-Point Temperatures } \\
0 \text { Particle Size Distribution } \\
\text { o Particle Composition } \\
0 \text { Particle Concentration } \\
0 \text { Excess Air } \\
0 \text { Measurement Techniques } \\
\end{array}$ & 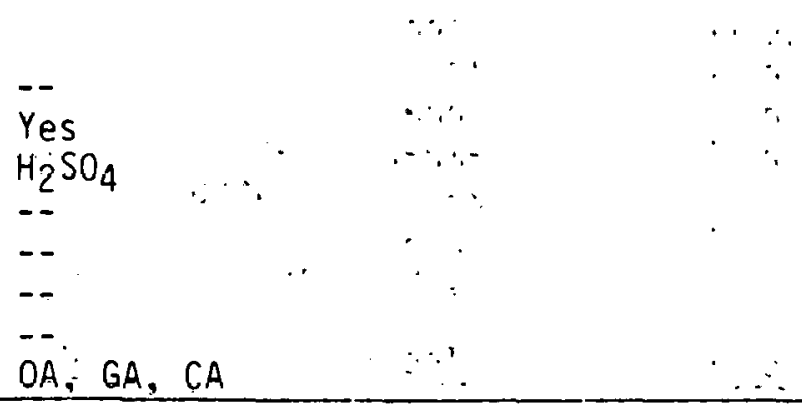 \\
\hline $\begin{array}{l}\text { Deposit Characterization } \\
0 \text { Constituents } \\
0 \text { Deposit Morphology } \\
0 \text { Deposit Melting Temperature } \\
0 \text { Corrosion Analysis } \\
0 \text { Deposit Mass } \\
0 \text { Measurement Techniques }\end{array}$ & $\begin{array}{l}\mathrm{H}_{2} \mathrm{SO}_{4} \\
-- \\
-- \\
-\bar{Y} \\
\text { Yes (Mass Deposition Rate Reported) } \\
\text { Not Specified } \quad \therefore\end{array}$ \\
\hline
\end{tabular}


Table 4-31. Gas-Side Fouling Probe Survey Matrix:

Land Pyrometers Limited, Dronfield, Sheffield, United Kingdom

\begin{tabular}{|c|c|c|}
\hline Reference $(s)$ & Land (84) & \\
\hline Type of Probe & Acid Condensation & \\
\hline Fuel & $0 i 1$ & \\
\hline Secondary Fluid & Air & \\
\hline $\begin{array}{l}\text { Probe: } \\
\text { o Geometry } \\
\text { o Wall Material/. } \\
\text { Interchangeable } \\
\text { - Location }\end{array}$ & $\begin{array}{l}\text { Thimble: } d=1.0 \mathrm{in.} \\
\text { Glass/Yes } \\
\text { Industrial Boiler }\end{array}$ & $\begin{array}{c}\quad \therefore \\
\therefore \\
\because \\
\because\end{array}$ \\
\hline Heat Flux & $\therefore \cdots$ & $\cdots$ \\
\hline Heat Balance & $\begin{array}{lll}\cdots & \cdots & \cdots \\
\end{array}$ & \\
\hline $\begin{array}{l}\text { Temperature: } \\
0 \text { Gas } \\
0 \text { Probe Wall } \\
0 \text { Probe Wall, Control }\end{array}$ & $\begin{array}{l}320-554 \mathrm{~F} \\
176-302 \mathrm{~F} \\
\text { Yes }\end{array}$ & $\begin{array}{r}\cdots \\
\cdots \\
\therefore \\
\because \cdots \\
\because\end{array}$ \\
\hline Thermal Boundary, Condition. & Constant Wall Temperature & $\therefore \cdots$ \\
\hline Maximum Sampling Period & Yes (Not Reported) & -1 \\
\hline $\begin{array}{l}\text { Gas-Side: } \\
0 \text { Velocity } \\
0 \text { Turbulence Intensity } \\
0 \quad \text { Fouling Factor } \\
\end{array}$ & $\begin{array}{l}\ddots \\
-- \\
-- \\
-\end{array}$ & $\begin{array}{l}\ddots \ddots \\
\ddots \\
\end{array}$ \\
\hline $\begin{array}{l}\text { Gas Characterization } \\
\text { o Fuel Analysis } \\
\text { o Gaseous Components } \\
\text { o Dew-Point Temperatures } \\
\text { o Particle Size Distribution } \\
\text { o Particle Composition } \\
\text { - Particle Concentration } \\
\text { o Excess Air } \\
0 \text { Measurement Techniques } \\
\end{array}$ & $\begin{array}{l}- \\
\mathrm{Partial}_{2} \\
\mathrm{H} \mathrm{SO}_{4} \\
\mathrm{30} \\
\mathrm{Not} \text {. percent } \\
\end{array}$ & $\begin{array}{ccc}\cdots & \ddots & \cdots \\
\ddots & \ddots & \\
& \ddots & \\
\ddots & \ddots & \\
\ddots & \\
\ddots & \ddots \\
& \ddots & \\
& \ddots & \end{array}$ \\
\hline $\begin{array}{l}\text { Deposit Characterization } \\
\text { o Constituents } \\
\text { o Deposit Morphology } \\
\text { o Deposit Melting Temperature } \\
\text { o Corrosion Analysis } \\
\text { o. Deposit Mass. } \\
0 \text { Measurement Techniques }\end{array}$ & $\begin{array}{l}\mathrm{H}_{2} \mathrm{SO}_{4} \\
-- \\
-- \\
-- \\
\text { Yes (Not Reported) } \\
\text { Not Specified }\end{array}$ & \\
\hline
\end{tabular}


Table 4-32. Gas-Side Fouling Probe Survey Matrix:

Technical Center of Industries Aerauliques, Villeurbanne, France

\begin{tabular}{|c|c|}
\hline Reference (s) & Dietz and Marchal (85) \\
\hline Type of Probe & Acid Condensation \\
\hline Fuel & Heavy Fuel 0 il \\
\hline Secondary Fluid & Air \\
\hline $\begin{array}{l}\text { Probe: } \\
\text { o Geometry } \\
\text { o. Wall Material/ } \\
\text { Interchangeable } \\
\text { o Location } \\
\end{array}$ & $\begin{array}{l}\text { Cylinder: } d=0.787 \text { in. } \\
\text { Stainless Steel/Yes } \\
\text { Laboratory }\end{array}$ \\
\hline Heat Flux & -- \\
\hline Heat Balance & -- \\
\hline $\begin{array}{l}\text { Temperature: } \\
\text { o Gas } \\
\text { o Probe Wall } \\
\text { o Probê Wall, Control }\end{array}$ & $\begin{array}{l}342-410 \mathrm{~F} \\
113-293 \mathrm{~F} \\
\text { Yes }\end{array}$ \\
\hline Thermal Boundary Condition & Constant Wall Temperature \\
\hline Maximum Sămpling Period & $1.5 \cdot h r$ \\
\hline $\begin{array}{l}\text { Gas-Side: } \\
\text { o Velocity } \\
\text { o Turbilence Interisity } \\
\text { o Fouling Factor } \\
\end{array}$ & $\begin{array}{l}26.3-78.7 \mathrm{ft} / \mathrm{sec} \\
-- \\
-\end{array}$ \\
\hline $\begin{array}{l}\text { Gas Characterization } \\
\text { o Fuel Analysis } \\
0 \text { Gaseous Components } \\
0 \text { Dew-Point Temperatures } \\
0 \text { Particle Size Distribution } \\
\text { o Particle Composition } \\
\text { o Particle Concentration } \\
0 \text { Cxcess Air } \\
0 \text { Measurement Techniques } \\
\end{array}$ & $\begin{array}{l}-- \\
\text { Partial : } \\
\mathrm{H}_{2} \mathrm{O}, \mathrm{H}_{2} S ! \\
-- \\
-- \\
0.00287-0.632 \text { grains } / \mathrm{ft}^{3} \\
-- \\
\text { Not Specified }\end{array}$ \\
\hline $\begin{array}{l}\text { Deposit Characterization } \\
\text { o Constituents } \\
\text { o Deposit Morphology } \\
\text { o Dcposit Melt ing Tcmperature } \\
0 \text { Corrosion Analysis } \\
\text { o Deposit Mass } \\
0 \text { Measurement Techniques }\end{array}$ & $\begin{array}{l}\text { Yes } \\
-- \\
-- \\
-- \\
\text { Yes (Mass Deposition Rate Reported) } \\
\text { CA }\end{array}$ \\
\hline
\end{tabular}




\section{SECTION 5}

\section{RECOMMENDATIONS FOR THE DESIGN OF A GAS-SIDE FOULING PROBE}

$\therefore$.. The recommendations relating to probe desian requirements, along with the requitred gas and deposit characterization analyses, are summarized in this. section. Also included is.a.short, descriptive analysis of the measurements which must.be made, along with some of the problems which are encountered, in.. order. to experimentally determine gas-side fouling factors, or resistances......

\subsection{REQUIREMENTS FOR CHARACTERIZATION OF COMBUSTION GASES}

$\because \because$ The importance of gas characterization measurements was emphasized in.... Section 3. Briefly, the minimum amount of gas characterization which must b.e carried out in connection: with the collection and analysis of gas-side foul-ing. deposits is as follows:

(a) Fuel Analysis

(b) Gaseous Components

(c) Dew-Point Temperatures

(d) Particle Size Distribution

(e) Particle Composition

(f) Particle Concentration.

(g) Excess Air.

A variety of techniques is available to carry out the necessary analyses to... determine these quantities.

\subsection{GAS=SIDE FOULING PRORE. REQUIREMENTS}

It is apparent that certain requirements must be satisfied regardless of the type of gas-side fouling measuring device if a thorough investigation is 
to be carried out. However, it is also apparent that very few of the devices which have been developed and used to date have the capability of measuring gas-side fouling factors on-line, or in situ, as a function. of time. Therefore, after listing those requirements which a gas-side fouling probe should satisfy, a brief consideration of the measurement of gas-side fouling factors is presented.

Probe Requirements

(a) The measuring device must be sturdy, yet simple in construction, and easy to install and remove from the qas stream., $\quad \because$.

(b) The probe must have a reasonably long life under arduous operating conditions.

(c) The probe should be lightweight and designed so that it can be installed in a varicty of typicol industrial gas streams.

(d) The probe test section must be large enough to permit the collection of adequate quantities of deposit for further analysis.

(e) The local wall temperature of the test section must be maintained at a constant temperature during any given test.

(f) The wall temperature of the measuring device should be easily controlled, preferably by automatic means, over a wide range of values with simultancous investigations at several temperatures highly desirable.

(g): In order to determine on-line fouling factors or resistances, the wall heat flux, gas temperature near the probe; surface temperature, and gas velocity must be simultaneously monitored as a function of time.

(ii) The probe should be equipped with a safety device in the event that its cooling system becomes inoperative. 
(i) The ability to easily interchange probe surface materials is essential.

$(j)$. Provisions should be made to ensure that none of the deposit falls off the probe, from the time it is removed from the gas stream unt il its mass is determined.

(k) Aithough difficult, it is highly desirable that the heat flux on both the gas-side and the secondary side be measured so that. a valid heat balance is confirmed.

(1) Although not absolutely essential, it is highly desirable that the measuring device be in the shape of a cylinder because of the

$\because \quad$ practical importance of this geometry.

(m) Automatic data acquisition is essential for successful long-term operation of the probe.

Measurement of Gas-Side. Fouling Factor

Consider the situation depicted in Fig. 5-1 showing the flow of a gas with free steam velocity, $\dot{V}_{g}$, and gas temperature, $\dot{T}_{g}$, over a surface at temperature, Tw. Initially, the surface is clean, but gradually a fouling layer builds up as indicated. Assuming a fouled layer of thickness $t_{f}$ as shown, :

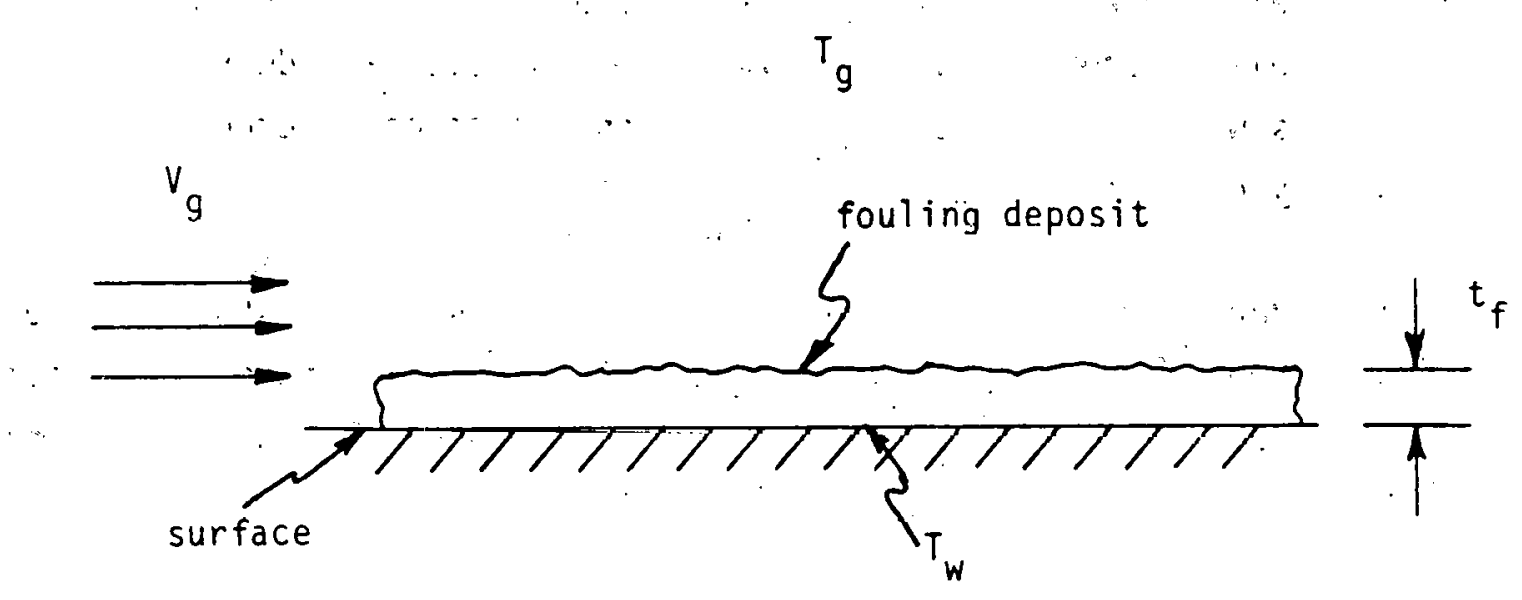

Fiqure 5-1. Schematic View of a Fouled Surface 
the heat transfer from the gas to the surface in an environment where radiation heat transfer is neqligible is

$$
q_{W}^{\prime \prime}=q / A=\left(r_{g}-T_{W}\right) /\left(1 / h+R_{f}\right) \cdot
$$

where $q_{w}^{\prime \prime}$ is the heat flux (heat transfer per unit area, $g / A$ ), $h$ is the convective heat transfer coefficient, and $R_{f}$ is the fouling resistance. The " fouling resistance is given by

$$
R_{f}=t_{f} / k_{f}
$$

where $k_{f}$ is the thermal conductivity of the fouling layer. Although the processes governing Eus. 5-1 and 5-2 are clearly unsteady ones, these equations may be used at any instant of time on a quas $i$-steady basis if the changes with lime dre rlot too great.

- In order to determine the buildup of the fouling resistance as a function of time, the following quantities must be monitored as a function of time:
(a) Gas Temperature, $T_{Q}$
(b) Wali heat Flux, $\mathrm{q}_{w}^{\prime \prime}, \cdots, \because$ is $\quad \cdots$.
(c) Wall remperature, $T_{W}$
(d) Heat Transfer Coefficient, $h$.

Unfortunately, there are several problem. First, most gas-side fouling measuring devices are controlled such that the local wall temperature remains constant as the fouling layer is deposited, thus resulting in a variable wall heat flux with timc. Therefore, the heat flux must be measured as a translent quantity; either on the gas-side or the secondary side (or preferably on both: sides in order to have a heat balance). Heat flux meters - are discussed in: Section 3.1 -- have been used to a limited extent to determine the gas-side. heat flux in fouling applications, primarily in radiation heat transfer .' equipment. On the secondary side of the measuring device, application of the. First Law of Thermodynamics may be used to calculate $q$ by the relation

$$
q=W C_{p}\left(T_{2}-T_{1}\right)
$$


where $W$ is the coolant mass flowrate, $C_{p}$ is the coolant constant-pressure specific heat, and $T_{1}$ and $T_{2}$ are the inlet and outlet coolant temperatures, respectively. Of course, the difference between $T_{2}$ and $T_{1}$ must be sufficiently large to ensure an accurate determination of $q$. Second, according to Eq. 5-1, in order to make an accurate determination of $R_{f}$, the convective heat transfer coefficient must be predicted accurately. In general, the Nusselt number, $\mathrm{Nu}$, defined by the relation

$$
\mathrm{Nu}=\mathrm{hL} / \mathrm{k}
$$

is a dimensionless heat transfer coefficient where $L$ is a characteristic lenath, usually taken as the diameter, d, for a cylinder. In the application at hand, the Nusselt number will. be a function; of the. Reynolds number, Prandt.l. number, and the geometry of the measuring device

$$
\begin{aligned}
& \therefore \therefore \quad \mathrm{Nu}=\mathrm{Nu}(\operatorname{Re}, \operatorname{Pr}, \text { geometry }) \quad r, \quad \because \quad \because \because \quad \because, \\
& \text { or in terms of dimensional variables }
\end{aligned}
$$

$$
h=h\left(V_{g}, \text { fluid properties, geometry }\right) \quad, \quad \because \cdots
$$

$\because$

Therefore, a knowledge of the gas-side velocity $V_{\mathrm{g}}$ will. required for a determination of the convective heat transfer coefficient which may be expressed empirically as

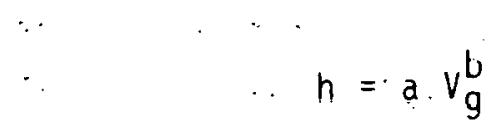

where $a$ and $b$ are coefficients which depend on the fluid properties and the . geometry. As the deposit builds up, it is possible that either a or, b, or:both, will change owing to the roughness of the fouled surface and, a change in the geometry of the surface. Although the area for other than a plane surface will change as the fouling layer is deposited, it has become customary to base the calculation of the fouling resistance on the clean surface, area, thereby avoiding that complication. 
In summary, in order to monitor the on-line foulino resistance, the heat flux, qas temperature, surface temperature, and gas velocity must be measured as a function of time. In addition, some knowledge of the effect of changes in geometry and surface roughness on the heat transfer coefficient may be required depending on the desired accuracy of the results. Finally, in high temperature applications the effect of thermal radiation must be taken into consideration.

\subsection{DEPOSIT ANALYSIS REQUIREMENTS}

As in the case of gas characterization, the importance of deposit characterization has also been seen throughout this report. These minimum. requirements are listed below: ...:
(a) Deposit Constituents
(b) Deposit Morphology
(c) Deposit Meliting Temperature.:
(d) Corrosion Analys is
(e) Deposit Mass.:

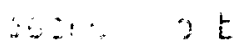

$\therefore$ 30

A varlety of techniques is available to carry out the necessary, analyses to.: determine these quantities. 


\title{
SECTION 6
}

\section{CONCLUDING REMARKS}

\begin{abstract}
$\because$ A survey of measuring devices, or probes, which have been used to investigate gas-side fouling has been carried out. Gas-side fouling measuring devices have been used in a number of settings including: utility and industrial boilers, municipal incinerators, Tand-based and shipboard gas turbines, Diesel exhausts, and heat recovery systems in a broad range of industries. Combustion gases ifrom Diesel fuel, coal, distillate and residual oils, JP-1, JP-5, SRC-II, black liquor, waste materials of various,types, and several simulated fuels have been tested. These environments have included. gases from modestly doped propane to coal-fired, potassium-seeded MHD exhausts and other process-contaminated industrial gas streams.
\end{abstract}

Five types of gas-side fouling measuring devices, have been ident ified and discussed including: heat flux meters, mass accumulation probes, optical devices, deposition probes, and acid condensation probes. Of. these five types, the major emphasis has been placed on mass accumulation probes (in which case the deposit mass is determined quantitatively to establish mass deposition rates) and on deposition probes (for which the deposit mass is not determined quantitatively, although the deposit itself may be analyzed quantitatively). The probes developed to date vary markedly in size and shape. Cylinders as small as 0.5-in. diameter and 0.5-in. length have been used as probes, as well as devices with 1.5-in. diameter and 13-ft length. The fixed cylinder has clearly been the most common geometry, but flat discs, ribbons, and rotating cylinders have also been used.

Many probes have been equipped with a cooling system, most of them utilizing air, to maintain the wall temperature of the measuring device at a constant temperature throughout the testing process. Even in those cases where the size of the probe results in temperature gradients along the length of the probe, the local wall temperature remains constant. Many of the probes have been successfully equipped with automatic wall temperature control systems. 
Finally, a number of probes have been designed to accommodate many different specimens, or segments, fastened together by threads, tension, or some other means. Thus, different materials or the same materials at different

temperatures may be tested at the same time. This technique has been very successful when studying the simultaneous effects of gas-side fouling and corrosion, a phenomena which occurs very frequently. Up to 34 individual segments have been used in a single probe.

Perhaps the most surprising result coming from this review is the determination that very few of the gas-side fouling probès which have been developed to date are capable of measuring on-line fouling factors as a function of time. In fact, Ruyalski (References 35-36), who made use ur a heat-pipe design which allowed-him to measure the wall heat flux, was the only investigator who actually reported fouling factors as a function of time. As discussed in Section 5, the wall heat flux, gas temperature, wali temperature, and gas velocity must all be measured simultaneously as a function of time if transient fouling factors are to be determined.

Finally, the criteria which a well-designed gas-side fouling probe must satisfy were discussed in Section, 5 . Iniaddition to the probe per se, the gas characterization and deposit characterization are also both very important, arid these requirements were also presented in Section 5. Although a significant amount of work has been done in the area of gas-side fouling probe development, it is clear that the design, construction, and testing of a durable, versatile probe -- capable of monitoring on-line fouling resistances -- remains a formidable task. 


\section{REFERENCES}

1. Engel, P.K., Silvestrini, R. and Thompson, R.E., "Corrosion and Fouling Potential in Diesel Exhausts," ASME Paper No. 78-WA/Fu-5, Presented at ASME Winter Annual Meeting, San Franciso, California. December 1978.

2. Engel, P.K., Thompson, R.E. and Silvestrini, R., "Corrosion and Fouling Potential in Diesel Exhausts," ASME Journal of Engineering for Power, Vol. 101, 1979, pp. 598-606.

3. Silvestrini, R., "Heat Exchanger Fouling and Corrosion, "Chemical Engineering Progress, Vo1. 75, No. 12, 1979, pp. 29-35.

4. Kindlimann, L. and Silvestrini, R., "Heat Exchanger Fouling and Corrosion Evaluation," Report Nos. 78-15161(1) and (2)., AiResearch Manufacturing. Company of California, Torrance, California, April 1979.

5. "Acid Corrosion and Fouling of Extended. Surfaces in Diesel Engine Exhaust Streams," IEA Collabor at ive Program for Energy Conservation -- Heat Transfer and Heat Exchangers, Task: Extended Surface Heat Transfer, Final Report Contribution on Subtask 2, U.S. Department of Energy, Washington, D.C., April 1980.

6. De Anda, E., "Heat Exchanger Fouling and Corrosion Evaluation," Report No. 81-18003, AiResearch Manufacturing Company of California, Torrance, California, June 1981.

7. Semler, T.T., Boque, J.L., Hensiee, S.P. and Casper, L.A., "Fouling of a Finned-Tube Diesel Flüe Gas Hëat Recuperator," Presented at the International Conference on Fouling of Heat Exchanger Surfaces, White Haven, Pennsylyania, November 1982.

-8... Henslee, S.P. and Bogue, J.L., "Fouling of a Finned-Tube Heat Exchanger in the Exhaust of a Stationary Diesel Engine: Final Report," Report No. EGG-FM-6189, EG\&G Idaho; Inc., Idaho Falls, Idaho, March 1983.

9. Kulkarni, A.K., Yang, W.J. and Webb, R.L., "Fouling and Corrosion in Glass Furnace Regenerators," Presented at the International Conference on Fouling of Heat Exchanger Surfaces, White Haven, Pennsylvania, November 1982.

10. Webb, R.L., Marchiori, D., Durbin, R.E., Yang, W.J. and Kulkarni, A.K., "Heat Exchangers for Secondary Heat Recovery from Glass Plants," Presented at the International Conference on Fouling of lleat Exchanger Surfaces, White Haven, Pennsylvania, November 1982.

11. Webb, R.L. and Kulkarni, A.K., "Heat Exchanger Needs for Recovering Waste Heat in the Glass Making Industry," Final Report, DOE Contract DE-FG07-81ID12225, The Pennsylvania State University, University Park, Pennsylvanià, February 1983.

12. Marner, W.J., "An Assessment of Gas-Side Fouling in Cement Plants, " Report No. 82-83, Jet Propulsion Laboratory, California Institute of Technology, Pasadena, California, September 1982. 
13. Berger, R.E., "Fouling and Acid Corrosion of an Oraanic Rankine Bottoming System Vaporizer Exposed to Diesel Engine Exhaust, Easton, Maryland," Report No. AER 1835, Sundstrand Aviation Operations, Rockford, Illinois, October 1980.

14. Niqgeman, R.E. and Greenlee, W.J., "The Design, Performance and Operating Experience of the Heat Transfer Equipment in Sundstrand $600 \mathrm{KW}$ Orqanic Rankine Bottoming Cycle," Advancement in Heat Exchangers, International Centre for Heat and Mass Transfer 1981 Summer Seminar, Dubrovnik, Yugoslavia, September 1981.

15. Greenlee, W.J. and Berger, R.E., "Gas-Side Fouling Experience in the Waste Heat Boiler of a 600 KWe Organic Rankine Bottoming Cycle, "Presented at the International Conference on Fouling of Heat Exchanger Surfaces, White Haven, Pennsylvania, November 1982.

16. Cole, W.E., "Investigation of Waste Heat Recovery Utilizing Fluidized Bed Heat. "Exchangers,"-Report. No. R78-912942, United Technologies Research"." Center, East·Hartfọrd, Connecticut, November 1978.

17. Cole, W.E. and Suo, M., "Waste Heat Recovery with Fluidized Beds," Chemical Engineering Progress, Vol. 75, No. 12, 1979, pp. 38-42.

18. Williams, H.W., Hernandez, R. and Mah, C.S., "Choosing the Optimum Bed Material for a Fluidized Bed Heat Exchanger," Paper No. 819302, Proceedings of the 16th Intersociety Energy Conversion Engineering Conference, Atlanta, Georgia, August 1981.

19. Rudnicki, M.I., Mah, C.S. and Willifams, H.W., "Status of Fluidized Bed Waste Heat Recovery," in Taborek, J., Hewitt, G.F. and Afgan, N. (Editors), Heat Exchangers: Theory and Practice, Hemisphere, Washington, D.C. 1983, pp. 549-568.

20. Miller, D. "Plastic Heat Exchangers: A State-of-the-Art Review," Report

... No. ANL 79-12, Argonne National Laboratory, Argonne, Illinois, January 1979.

21. Marner, W.J. and Webb, R.L. (Editors), "Workshop on An Assessment of Gas-Side Fouling in Fossil Fuel Exhaust Environments, "Report No. 82-67, Jet Propulsion Laboratory, California Institute of Technology, Pasadena, California, July 1982.

22: Marner, W.J., Webb, R.L. and Thielbahr, W.H., "Workshop on An Assessment of Gas-Side Fouling in Fossil Fuel Exhaust Environments, "Presented at the International Conference on fouling of Heat Exchanger Surfaces, White Haven, Pennsylvania, November 1982.

23. Marner, W.J. and Webb, R.L., "A Bibliography on Gas-Side Fouling," Proceedings of the ASME-JSME Thermal Engineering Joint Conference, Vol. 1, ASME; New York, 1983, pp. 559-570.

24. "Corrosion and Deposits from Combustión Gases: Abstract and Index," Battelle Memorial Institute, Columbus Laboratories, Columbus, Ohio, 1970. 
25. Fisher, P., Suitor, J.W. and Ritter, R.B., "Fouling Measurement Techniques," Chemical Engineering Progress, Vol. 71, No. 7, 1975, pp. $66-72$.

26. Knudsen, J.G., "Apparatus and Techniques for Measurement of Fouling of Heat Transfer Surfaces," in Somerscales, E.F.C. and Knudsen, J.G. (Editors), Fouling of Heat Transfer Equipment, Hemisphere, Washington, D.C., 1981, pp. 57-81.

27. Northover, E.W. and Hitchcock, J.A., "A Heat Flux Meter for Use in Boiler Furnaces," Journal of Scientific Instruments, Vol. 44, 1967, pp. 371-374.

28. Neal, S.B.H.C. and Northover, E.W., "The Measurement of Radiant Heat Flux in Large Boiler. Furnaces -- I. Problems of Ash Deposition Relating to Heat Flux," International Journal of Heat and Mass Transfer, Vol. 23, 1.980, pp. 1015-1021.

29. Neal, S.B.H.C., Northover, E.W. and Preece, R.J., "The Measurement of Radiant Heat Flux in Large Boiler Furnaces -. II. Development of Flux Measuring Instruments," International Journal of Heat and Mass Transfer,

Vol. 23.: 1980, pp. 1023-1031.

30. Chambers, A.K., Wynnyckyj, J.R. and Rhodes, E., "Development of a Monitoring System for Ash Deposits on Boiler Tube Surfaces," The Canadian Journal of Chemical Engineering, Vol. 59, 1981, pp. 230-235.

31. Chambers, A.K., Wynnyckýj, J.R. "and Rhodes, E: $\because A$ Furnace Wall Ash Monitoring System for Coal Fired Boilers," ASME Journal of Engineering for $\therefore$ Power, Vo1. 103, 1981, pp. 532 - 5338 .

32.: Brown, T..D., "The Deposition of Sodium Sulphate from Combustion Gases," Journal of the Institute of Fuel, Vol. 39, 1966, pp. 378-385:

33. Hedley, A.B., Brown, T.D. and Shuttleworth, A., "Vanadium Pentoxide Deposition from Combustion. Gases," ASME Journal of Engineering for Power, Vol. 88, 1966, pp. 173-178.

34. Hein, K., "Characteristics of Rheinisch Brown Coals with Respect to Their Combustion and Fouling Behavior in Thermal Power Stations," ASME Journal of Engineerilly Für Power, Vol. 99, 1977, pp.679-683..:

35. Rogalski, R.D., "Fouling Effects of Turbine Exhaust Gases on Heat Exchanger Tubes for Heat Recovery Systems," Report No. DTNSRDC/PAS-79/5, Davlu W. Taylui Naval Ship Rescarch and Davelopment Conter, Rethesda, Maryl and, February 1979.

36. Rogalski, R.D., "Fouling Effects of Turbine Exhaust Gases on Heat Exchanger Tubes for Heat Recovery Systems," SAE Transactions, Vol. 88, Sectiorl 3, Nu. 790647, 1979, pp. 2223-2239.

37. Oka, S., Kostic, M. and Repic, B., "An Experimental Furnace for Investigation of Combustion and Ash Deposit Processes of Pulverised Coal," in Savic, D. and Opik, I. (Editors), "Fouling and Corrosion in Steam Generators," Boris Kidric Institute of Nuclear Sciences, Vinca, Beograd, Yugoslavia, 1980, pp. 135-144. 
38. Lin, C.J. and Winegartner, E.C., "Coal Ash Fouling Test in a Laboratory Furnace," ASME Paper No. 81-JPGC-Fu-8, Presented at the Joint ASME/IEEE Power Generation Conference, St. Louis, Missouri, October 1981.

39. Jackson, P.J. and Raask, E., "A Probe for Studying the Deposition of Solid Material from Flue Gas at High Temperatures," Journal of the Institute of Fuel, Vol. 34, 1961, pp. 275-280.

40. Jackson, P.J., "Deposition of Inorganic Material in Oil-Fired Boilers," in Bryers, R.W. (Editor), Ash Deposits and Corrosion Due to Impurities in Combustion Gases, Hemisphere, Washington, D.C., 1978, pp. 147-161.

41. Dalmon, J., Tidy, D. and Towe11, D.E., "A Surface Sampler for Measuring Solids and Acid Deposition onto the Flue-Duct Walls of 0il-Fired Boilers: the CERL Deposition Sampler," Journal of the Institute of Fuel, Vol. 51, 1978, pp. 202-205.

42. Isdale, J.D., National Engineering Laboratory, East Kilbride, Glasqow, . Scottland, Personal Communication, January 1983.

43. Isdale, J.U., Scott, A.C. án Cartwright, G., "Report on Fouling in Diesel Exhausts, "Prepared for International Eneray Agency Programme of Research and Development on Energy Conservation in Heat Transfer and Heat

Exchangers, National Engineering Laboratory, Glasgow, Scotland, June 1983.

44. Holland, N.H., O'Dwyer, D.F., Rosborough, D.F. and Wright, W., "High-Temperature Corrosion Investigations on an 0il-Fired Boiler at Marchwood Power Station," Journal of the Institute of Fuel, Vol. 41, 1968, pp. 206-218.

45. Koh1, F.J., Santoro, G.J.; Stearns, C.A., Fryburg, G.C. and Rosner, D.E., "Theoretical and Experimental Studies of the Deposition of $\mathrm{Na}_{2} \mathrm{SO}_{4}$ from Seeded Combustion Gases," Journal of the Electrochemical Society: Solid-State Science and Technology, Vol: 126, 1979, pp. 1054-1061.

46. White, D.J., "Effects of Gas Turbine Combustion on Soot Deposition," Report No. SR79-R-4643-03;: Solar. Turbines International, San Diego, California, March 1979.

47. Horn, G. and Street, P.J., "Experiments with a Pilot Plant Desiqned to. Superheat Steam to $760^{\circ} \mathrm{C}$ : Part 1.' Development and Instrumentation for Corrosion Studies," Journal of the Institute of Fuel, Vol. 41, 1968, pp. 152-161.

48. Horn, G, and Street, P.J., "Experiments with a Pilot Plant Designed to Superheat Steam to $760^{\circ} \mathrm{C}$ : Part 2. Flame and Deposition Studies, Journal of the Institute of Fuel, Vol. 41, 1968, pp. 219-232.

49. Horn, G. and Street, P.J., "Experiments with a Pilot Plant Designed to Superheat Steam to $760^{\circ} \mathrm{C}$ : Part 3. Behaviour of Three High-Tcmperature Alloys," Journal of the Institute of Fuel, Vol. 41, 1968, pp. 258-264. 
50. Gronhovd, G.H., Beckering, W. and Tufte, P.H., "Study of Factors Affecting Ash Deposition from Lignite and Other Coals," ASME Paper No. 69-WA/CD-1, Presented at the ASME Winter Annual Meeting, Los Angeles, California, November 1969.

51. Tufte, P.H. and Beckering, W., "A Proposed Mechanism for Ash Fouling $\because \therefore$ Burning Northern Great Plains Lignite," ASME Journal of Engineering for Power, Vol. 97, 1975, pp. 407-412.

52. Sondreal, E.A., Tufte, P.H. and Beckering, W., "Ash Fouling in the Combustion of Low Rank Western U.S. Coals," Combustion Science and Technologv, Vol. 16, 1977, pp. 95-110.

53.: Sondreal, E.A., Gronhovd, G.H., Tufte, P.H. and Beckering, W., "Ash Fouling Studies of Low-Rank Western U.S. Coals," in Bryers, R.W. (Editor), Ash Deposits and Corrosion Due to Impurities in Combustion Gases, Hemisphere, Washington, D.C., 1978, pp. 85-111.

54. DeCorso, S.M., Vermes, G., Lee, S.Y., Singhal, S.C. and Cohn, A., "Combustion Turbine Design Guidelines Based on Deposition/Corrosion Considerations," ASME Paper No. 80-GT-72, Presented at the Gas Turbine $\therefore$ Conference \& Products Show, New Orleans; Louisiana, March 1980.

55... Whitlow, G:A., Lee, S.Y., Mulik, P.R., Wenglarz, R:A., Sherlock, T.P. and Cohn, A., "The High-Temperature Combustion of Residual Fuel 0il.-.- Some Deposition Product Considerations," Presented at the EPRI/DOE 2nd Conference on Advanced Materials.for Alternative. Fuel-Capable Heat Engines, Monterey, California, Augu'st $1981^{\circ}$.

56. Whitlow, G.A., Lee, S.Y., Mulik, P.R., "Wenglarz, R.A., Sherlock, T.P. and Cohn, A., "Combustion Turbine Deposition Observations from Residual and Simulated Residual 0il Studies," ASME Journal of Engineering for Power, Vol. 105, 1983, pp. 88-96.

57. Spengler, C.J., Whitlow, G.A., Lee, S.Y., Wenglarz, R.A..and Mulik, P.R., "Corrosion and Deposition Results from Pressurized Passage Tests with Heavy Ash Bearing Fuels from the SRC-II Process," ASME Paper No. 83-GT-185, Presented at the 28th International Gas Turbine Conference and Exhibit, Phoenix, Arizona, March 1983.

58. $\because$ Bishop, R.J. and Cliffe, K.R., "Condensation Behavior of Sodium Chloride $\because$ during Convective Heat Transfer," Journal of the Institute of Fuel, Vol. 43, 1970, pp. 441-448.

59. Rosner, D.E., "Experimental Studies of the Formation/Deposition of Sodium Sulfate in/from Combustion Gases," Report No. NASA. CR-159612, Yale University, New Haven, Connecticut, May 1978.

60. Rosner, D.E. and Seshadri, K., "Experimental and Theoretical Studies of the Laws Governing Condensate Deposition from Combustion Gases, "Eighteenth

$\therefore$ Symposium (International) on Combustion, The Combustion Institute, Pittsburgh, Pennsylvania, 1981, pp. 1385-1394. 
61. Rosner, D.E. and Atkins, R.M., "Experimental Studies of Salt/Ash Deposition Rates from Combustion P.roducts Using Optical Techniques, "Presented at the International Conference on Experimental Research into Fouling and Slagging Due to Impurities in Combustion Gases, Henniker, New Hampshire, July 1981.

62. Reeve, D.W., Tran, H.N. and Barham, D., "The Effluent-Free Bleached Kraft Pulp Mill -- Part XI, $\therefore$ Pulp and Paper. Canada, Vol. 82,1981 ; pp. 'T315-T320.

63. Reeve;, D.W., Tran, H.N. and Barham, D., "Superheater Fireside Deposits and. Corrosion in Kraft Recovery Boilers, TAPPI, The Journal of the Technical Association of the Pulp and Paper. Industry, Vol. 64, No. 5, 1981, pp. 109-113.

64. Tran, H.N., Reeve, D.W. and Barham, D., "Formation of Kraft'Recovery Boiler Superheater Fireside Ueposits;" Pulp and Pàper Canada, Vol. 84, 1983, pp. T7-T12.

65. Barkley, J.F., Burdick, L.R. and Berk, A.A., "Test Data on Gas-Side Sulphate-Type Deposits on Tubes Beyond Boiler Furnace." Transirilinns nf. the ASME',' 1948, Vol. 70 , pp. 81-89.

66. Durie, R.A., Milne, J.W. and Smith, M.Y., "The Deposition of Salts from Hydrocarbon "Flames Containing Sodium and Sulphur Species, "Combustion and 'Flame; Vo 1.: 30, 1977, pp.' 221-230.

67. White, M.K. and Attig, R.C., "Ash Deposition in MHD Bottoming Plant Components, it. Presented at the International Conference on Fouling of Heat Exchanger Surfaces, White Haven, Pennisylvania, November 1982.

68. Miller, P.D. and Krause, H.H., "Factors Influencing the Corrosion of Boiler Steels in Muricipal Incinerators," Corrosion-NACE; Vol. 27,"No. 1, 1971, pp $\because 31-45$.

69. K̈rause, H.H., Vauqhan, D.A. and Miller. P.D. "Corrosinn and Menocit.s fram Combustion of Solid Waste," ASME Journal of Engineering for Power, Vol. 95, $1973 ;$ pp. $45-52$.

70. Krause, H.H., Vaughan, D.A. and Millier, P.D., "Corrosion and Deposits from Combustion of Solid Waste. Part II: Chlnride Fffects on Boiler Tube and Scrubber Metals," ASME Journal of Engineering for Power, Vol: 96, 1974,.. nn: plfi-22?.

71. Krause, H.H., Vaughan, D.A. and Boyd, W.K., "Corrosion and Deposits from Combustion of Solid Waste.: Part III: Effect.s nf Sulfur on Boiler Tube Metals," ASML Journal of Engineering for Power, Vol. 97, 1975, pp. $448-452$.

72. Krause, H.H.; Vaughan, D.A. and Boyd, W.K., "Corrosion and Deposits from Combustion of Solid Waste. Part IV: Combined Firing of Refuse and Coal," ASME Journal of Engineering for. Power, Vol. 98, 1976, pp. 369-374. 
73. Krause, H.H., Vaughan, D.A., Cover, P.W., Boyd, W.K. and Oberacker, D.A., "Corrosion and Deposits from Combustion of Solid Waste. Part V: Firing of Refuse with High Sulfur-Coal," ASME Journal of Engineering for Power, Vol. 99, 1977, pp. 449-459.

74. Vaughan, D.A., Krause, H.H. and Boyd, W.K., "Corrosion Mechanisms in Municipa, Incinerators Versus Refuse Composition," in Matula, R.A.

(Editior), Present Status and Research Needs in Energy Recovery from Wastes: Proceedings of the 1976 Conference, ASME, New York, 1977, pp. 182-209.

75. Vaughan, D.A., Krause, H.H. and Boyd, W.K., "Chloride Corrosion and Its Intibition in Refuse Firing," in Bryers,. R.W. "(Editor), Ash Deposits and" Corrosion Due to Impurities, in Combustion Gases, Hemisphere, Washington, D.C.; 1978, pp. 473-493.

76. . Krause, H.H., Cover, P.W., Berry, W.E. and Olexsey, R.A., "Corrosion and Deposits from Combustion of Solid Waste. Part VII: Coincineration of Refuse and Sewage Sludge," ASME Journal of Engineering for Power, Vol. 102, 1980, pp. 698-705.

77. $\because$ Plumley, A.L., Accortt, J.I. and Rocznjak, W.R., "Evaluation of Boiler Tube Materials for Advanced Power Cycles," Report No. TIS-6105, Combustion Engineering, Inc., Windsor, Connecticut, January 1979.

78. Plumley, A.L. and Roczniak, W.R., "Natural Occurring High-Chioride Coal and Superheater Corrosion - - A Laboratory Study,". ASME Journal of Engineering for Power, Vol. 104, 1982, pp. 874-884.

79, $\therefore$ Koopman, J.G., Marselli, E.M., Jonakin, J. and Ulmer, R.C., "Development and Use of a Probe for Studying Corrosion in Superheaters and Reheaters," Proceedings of the American Power Conference, Vol. 21, 1959, pp. 236-245.

80. $\because$ Krause, H.H., Rising, B.W. Anson, D., Radway, J.E. and Dimmer, J.P., "Performance of Fuel 0 il Additives on Simulated Superheater Surfaces," ASME Paper No. 82-JPGC-Fu-5, Presented at the Joint Power Generation Conference, Denver, Colorado, October 1982 .

81. Russel1, A.D., Smeltzer, C.E. and Ward, M.E., "Waste Heat Recuper.ation for Aluminum Furnaces," Report No. GRI-81/0160, Solar Turbines Incorporated, San Diego, California; April 1983.

82. Alexander; P.A., Fielder, R.S., Jackson, P.J. and Raask, E., "An Air-Cooled Probe for Measuring Acid Deposition in Boiler Flue Gases," Journal of the Institute of Fuel, Vol. 33, 1960, pp. 31-37.

83. . Ross, K.,. "Condensation of Sulphuric Acid From Flue Gas. on a Cooled Cylinder;" Journal of the Institute of Fuel, Vol. 37, 1964, pp. 273-277.

84. Land, T., "The Theory of Acid Deposition and Its Application to the $\because \because$ Dew-Point Meter," Journal of the Institute of Fuel, Vol. 50, 1977,

$\because$ pp. 68-75. 
85. Dietz, R. and Marchal, D., "Attempt to Predict Quantitatively the Acid Deposits Formed Downstream of Furnaces Operating on Heavy Fuel $011, "$ International Chemical Engineering, Vol. 17, 1977, pp. 583-591.

86. Henslee, S.P., Visit to United Kingdom includina AERE Harwell, Universitiy of Birmingham, Central Electricity Generating Board, Midlands Region . $\therefore$ Scientific Services Department, and: National Engineering Laboratory, $\because \because$ January 1983. 